INVESTIGATION OF CLASSROOM MANAGEMENT SKILLS BY USING EYE-TRACKING TECHNOLOGY

A THESIS SUBMITTED TO

THE GRADUATE SCHOOL OF NATURAL AND APPLIED SCIENCES $\mathrm{OF}$ MIDDLE EAST TECHNICAL UNIVERSITY

BY

ATAKAN ÇOŞKUN

IN PARTIAL FULFILLMENT OF THE REQUIREMENTS FOR

THE DEGREE OF MASTER OF SCIENCE

IN

COMPUTER EDUCATION AND INSTRUCTIONAL TECHNOLOGY

AUGUST 2019 

Approval of the thesis:

\section{INVESTIGATION OF CLASSROOM MANAGEMENT SKILLS BY USING EYE-TRACKING TECHNOLOGY}

submitted by ATAKAN ÇOŞKUN in partial fulfillment of the requirements for the degree of Master of Science in Computer Education and Instructional Technology Department, Middle East Technical University by,

Prof. Dr. Halil Kalıpçılar

Dean, Graduate School of Natural and Applied Sciences

Prof. Dr. Ömer Delialioğlu

Head of Department, Comp. Edu. and Inst. Tech.

Prof. Dr. Kürşat Çăğltay

Supervisor, Comp. Edu. and Inst. Tech., METU

\section{Examining Committee Members:}

Prof. Dr. Yaşar Kondakçı

Educational Sciences, METU

Prof. Dr. Kürşat Çağıltay

Comp. Edu. and Inst. Tech., METU

Prof. Dr. Oya Yerin Güneri

Educational Sciences, METU

Assoc. Prof. Dr. Yasemin Demirarslan

Comp. Edu. and Inst. Tech., Hacettepe University

Dr. Göknur Kaplan

Comp. Edu. and Inst. Tech., METU

Date: 05.08.2019 
I hereby declare that all information in this document has been obtained and presented in accordance with academic rules and ethical conduct. I also declare that, as required by these rules and conduct, I have fully cited and referenced all material and results that are not original to this work.

Name, Surname: Atakan Çoşkun

Signature: 


\begin{abstract}
INVESTIGATION OF CLASSROOM MANAGEMENT SKILLS BY USING EYE-TRACKING TECHNOLOGY

\author{
Çoşkun, Atakan \\ Master of Science, Computer Education and Instructional Technology \\ Supervisor: Prof. Dr. Kürşat Çağıltay
}

August 2019, 103 pages

This study investigates how a wearable eye tracker can be employed to assess and improve the visual attention of the faculty members in a higher education institution. Two experienced faculty members took part in the study. Both of them have been lecturing for more than ten years at the university, so they are experienced teachers. A wearable eye tracker was employed to assess and improve the participants' visual attention in relation to classroom management skills. Besides, eye-tracking data were supported by video camera recordings. Video camera was also employed to record the gestures of the participants in classroom environment. The data were gathered from each participant for three weeks. Among the weeks, Retrospective Think Aloud (RTA) sessions were implemented for the participants to explore their wrongs and rights about classroom management. In the RTA sessions, eye movements and video records were presented in synchronized way via a software. In the RTA sessions, the analysis results of eye movements were also presented for the participants to be interpreted. At the end of the third week, a short interview session was conducted with each participant. The findings showed that wearable eye tracker is a useful tool to assess the faculty members' visual attention in real-world classroom environments. As the wearable eye tracker gave informative feedback about visual perception of the faculty 
members, it contributed to the improvement of their visual attention about classroom management.

Keywords: Classroom Management, Teacher Training, Higher Education, Eye Contact, Eye-tracking 


\title{
Öz
}

\section{GÖZ İZLEME TEKNOLOJISİ KULLANARAK SINIF YÖNETİMİ BECERILERININ ARAŞTIRILMASI}

\author{
Çoşkun, Atakan \\ Yüksek Lisans, Bilgisayar ve Öğretim Teknolojileri Eğitimi \\ Tez Danışmanı: Prof. Dr. Kürşat Çağıltay
}

Ağustos 2019, 103 sayfa

$\mathrm{Bu}$ çalışma, bir yüksek öğretim kurumunda, fakülte üyelerinin sınıf yönetimi ile alakalı görsel dikkatini geliştirmek için giyilebilir göz takip cihazının nasıl kullanılacağını araştırmaktadır. Çalışmaya iki fakülte üyesi katılmış olup, katılımcıların her ikisi de 10 yıldan fazla bir sürelik deneyime sahiptir. Katılımcıların sınıf yönetimi ile alakalı görsel dikkatini değerlendirmek ve geliştirmek için giyilebilir bir göz takip cihazı kullanılmıştır. Ayrıca, göz izleme verileri, video kamera verileri ile desteklenmiştir. Aynı zamanda video kamera, katılımcıların vücut hareketlerini kaydetmek için kullanılmıştır. Veriler her katılımcıdan üç hafta boyunca toplanmıştır. Haftalar boyunca, katılımcıların, ders verme esnasında yaptıkları hataları ve doğruları keşfetmeleri için geriye dönük sesli düşünme oturumları uygulanmıştır. $\mathrm{Bu}$ oturumlarda göz hareketleri ve video kayıtları bir yazılımda senkronize olarak gösterilmiştir. Geriye dönük sesli düşünme oturumlarında, fakülte üyelerinin yorumlamaları için göz hareketlerinin analiz sonuçları da sunulmuştur. Üçüncü haftanın sonunda, her katılımcıyla kısa bir mülakat oturumu yapılmıştır. Bulgular, giyilebilir göz takip cihazının sınıf yönetimi ile alakalı görsel dikkati değerlendirmede yararlı bir araç olduğunu göstermiştir. Giyilebilir göz takip cihazı, sınıf yönetimi ile ilgili görsel algı hakkında bilgilendirici geri bildirim verdiği için, katılımcıların görsel dikkatinin iyileşmesinde rol oynanmıştır. 
Anahtar Kelimeler: Sınıf Yönetimi, Öğretmen Eğitimi, Yüksek Öğretim, Göz Teması, Göz Hareketleri Takibi Teknolojisi 
To my family who always supported and believed me throughout my life, and to my lovely cat who was disturbing me while writing the thesis 


\section{ACKNOWLEDGEMENTS}

I wish to express my deepest gratitude to my supervisor Prof. Dr. Kürşat Çağıltay for his guidance, advice, criticism, encouragements, and insight throughout the research. Also, I am so grateful for the unconditional support of my mother, Selma Çoşkun, my father, İbrahim Çoşkun and my sister, Merve Çoşkun.

I am extremely thankful to my darling, Selen Iş1k, for motivating me to complete my thesis.

I want to thank you my friend, Enver Y1lmaz, for opening his room at the Department of Mining Engineering in order for me to write my thesis.

I am so thankful to the developer of EKIS software, Sanam Dehghan, for allowing me to use this software.

I want to thank you manager, Metin Önder, for supporting my academic life.

I would like to thank the members of my thesis committee, Prof. Dr. Yaşar Kondakçı,

Prof. Dr. Oya Yerin Güneri, Assoc. Prof. Dr. Yasemin Demirarslan and Dr. Göknur Kaplan, for their advices and valuable comments.

Finally, I want to thank warmly to the participants for their providing data. 
TABLE OF CONTENTS

ABSTRACT

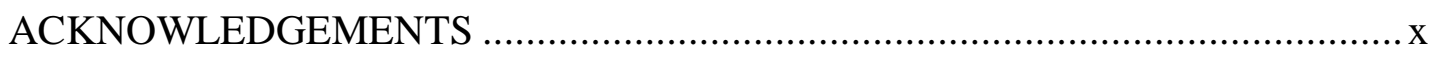

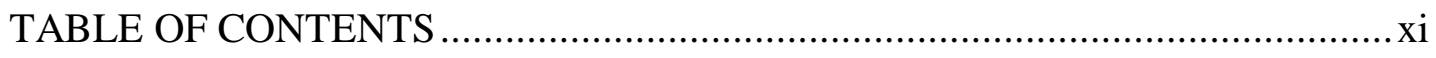

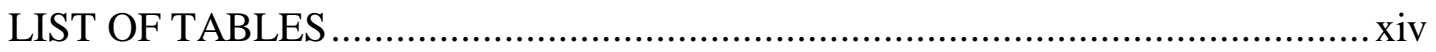

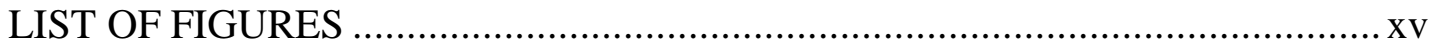

\section{CHAPTERS}

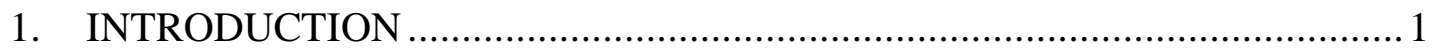

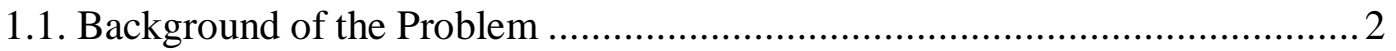

1.2. Statement of the Problem ........................................................................... 5

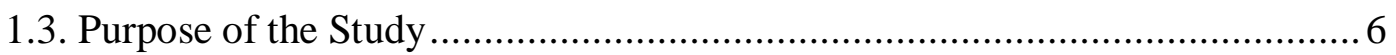

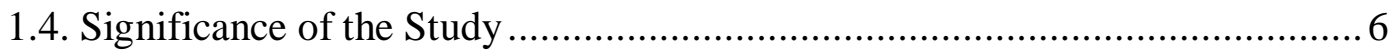

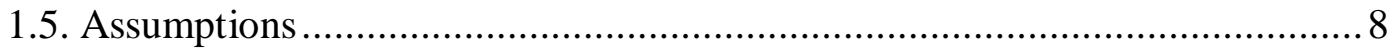

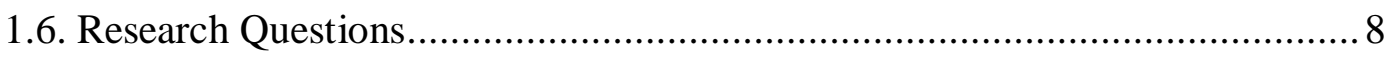

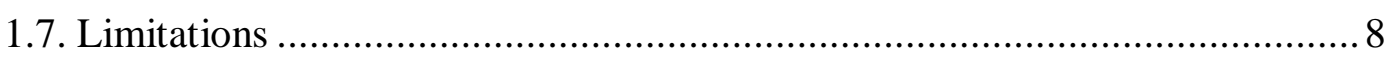

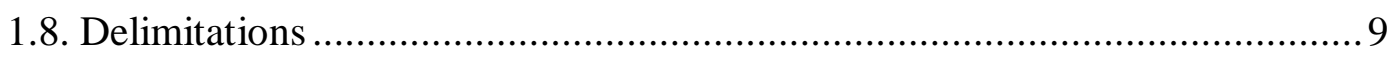

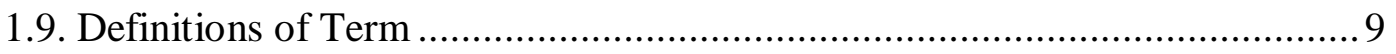

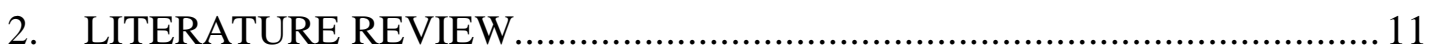

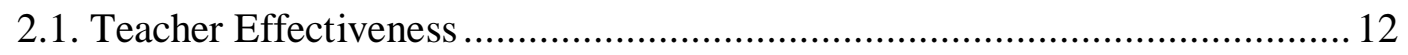

2.1.1. Classroom Management in Higher Education ...................................... 12 
2.1.2. Evaluation of Teaching in Higher Education .................................... 15

2.1.3. Training Higher Education Teachers .............................................. 17

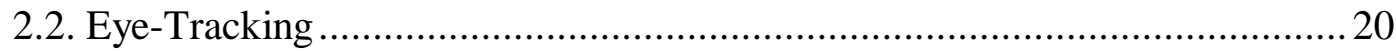

2.3. Eye Contact and Gestures in Classroom Management .................................2 21

2.4. The Relationship Between Eye Movements and Human Behaviors.............. 22

2.5. Eye-tracking as a Training and Assessment Tool ......................................23

2.6. Eye-tracking for Assessing Teachers' Visual Attention...............................23

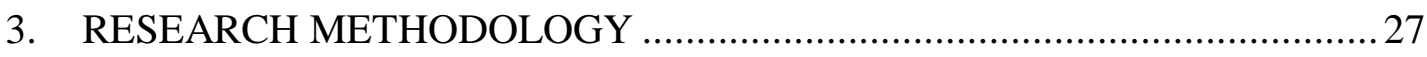

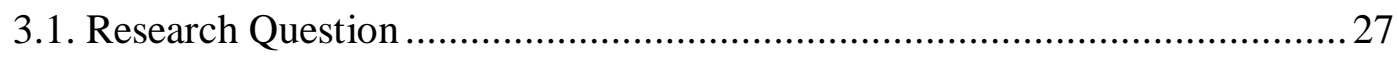

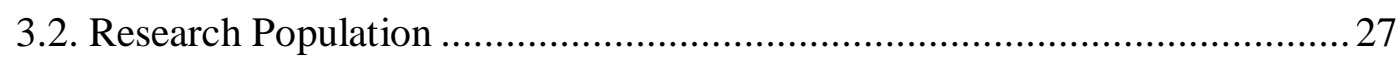

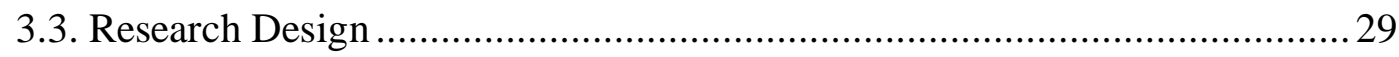

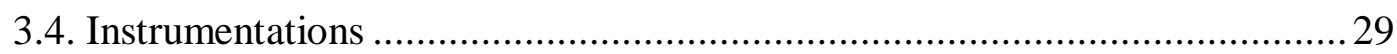

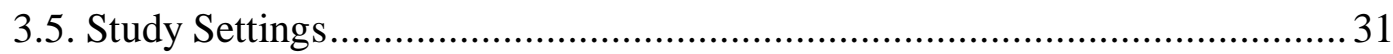

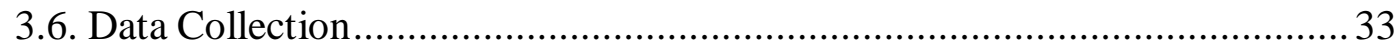

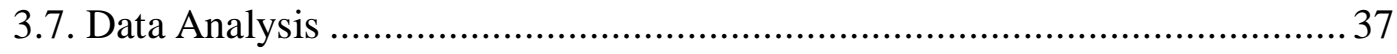

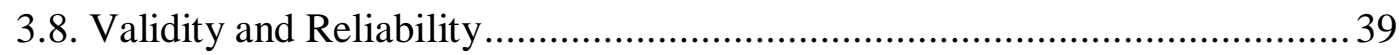

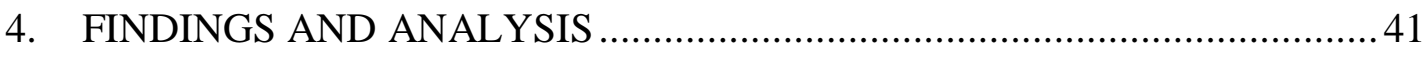

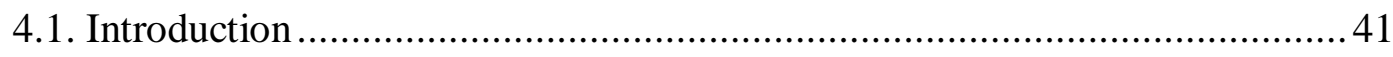

4.2. Gaze Analysis Results of the $1^{\text {st }}$ Participant ......................................... 41

4.2.1. The First Week........................................................................ 42

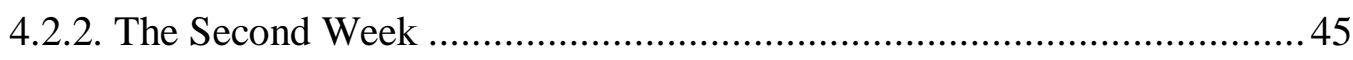

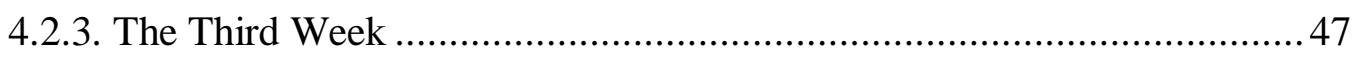

4.2.4. Interview with the $1^{\text {st }}$ Participant ................................................... 48

4.3. Gaze Analysis Results of the $2^{\text {nd }}$ Participant ............................................. 49 
4.3.1. The First Week. 50

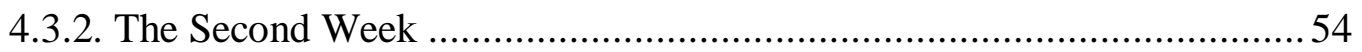

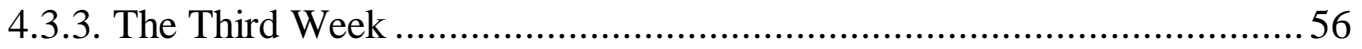

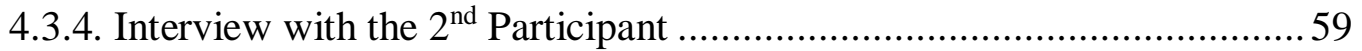

4.4. Weekly Comparison of the Data .......................................................5

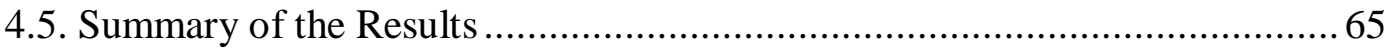

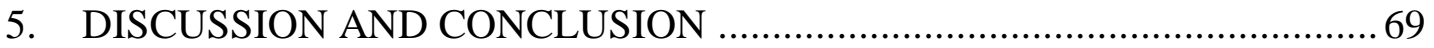

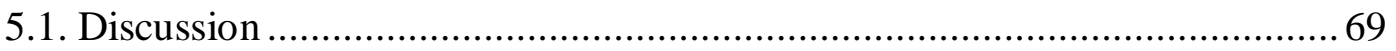

5.1.1. Faculty Members' Visual Attention Across the Students ....................... 70

5.1.2. Faculty Members' Visual Attention Across the Classroom .................... 74

5.1.3. Participants' Thoughts About Wearable Eye Tracker............................ 75

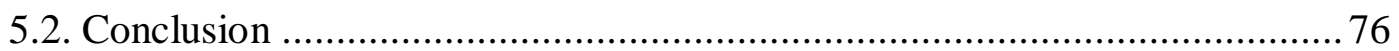

5.3. Limitations and Recommendations for Future Research............................ 78

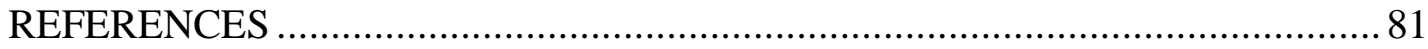

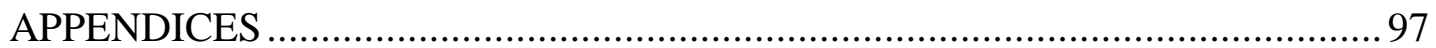

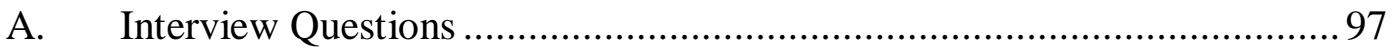

B. Voluntary Participation Form (Turkish) …........................................... 99

C. Ethics Approval Form (Turkish) …................................................. 103 


\section{LIST OF TABLES}

\section{TABLES}

Table 2-1: Commercial Wearable Eye Trackers .................................................... 21

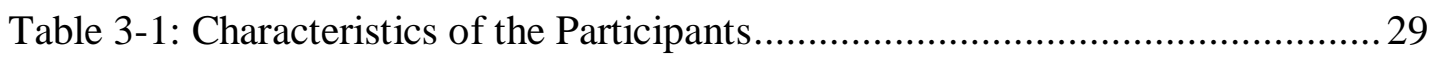

Table 3-2: Types of Classroom Environment …................................................ 32

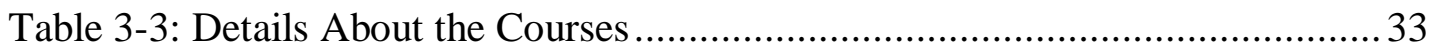

Table 3-4: Dates of Data Collection ..................................................................... 34

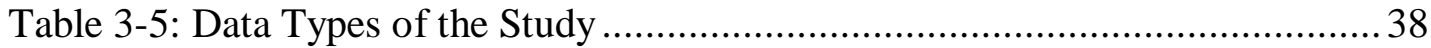

Table 4-1: Weekly Comparison of the 1st Participant's Data...................................60

Table 4-2: Weekly Comparison of the 2nd Participant's Data ................................63 63 


\section{LIST OF FIGURES}

\section{FIGURES}

Figure 2-1: Ways of Evaluation of Teaching Performance (\% of institutions) (European Commission et al., 2018 as cited in EUA, 2018, p.88) ......................... 16 Figure 2-2: \% of Universities Training Faculty Members (European Commission et al., 2018, as cited in EUA, 2018, p.58)..... 19

Figure 2-3: Heatmap of Novice and Expert Teachers' Glances (Bogert et al., 2014, p.213) 24

Figure 3-1: Tobii Pro Glasses 2 (A Wearable Eye Tracker, as cited in tobiipro.com) 30

Figure 3-2: Parts of Glasses 2 Head Unit (as cited in tobiipro.com) ....................... 30

Figure 3-3: A View Showing Video Camera Recording ......................................... 31

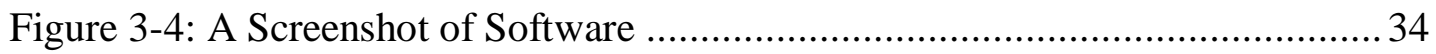

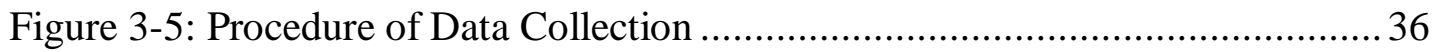

Figure 3-6: AOIs of the Traditional Classroom Environment ................................ 38

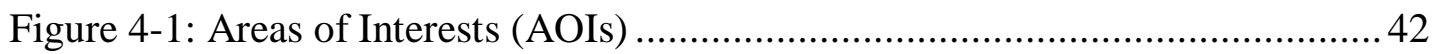

Figure 4-2: Percentage of Total Time Spent on the AOIs .................................. 43

Figure 4-3: Total Time Spent on the AOIs (min) ............................................... 43

Figure 4-4: \% of Total Time Spent on the Front and Back.................................. 44

Figure 4-5: Heatmap of the 1st Participant's Visual Attention (Left Area)..............44

Figure 4-6: Heatmap of the 1st Participant's Visual Attention (Right Area)............ 45

Figure 4-7: Total Time Spent on AOIs (min) ......................................................... 46

Figure 4-8: \% of Total Time Spent on the Front and Back................................... 46

Figure 4-9: Total Time Spent on AOIs (min)................................................... 48

Figure 4-10: Heatmap of the 1st Participant's Visual Attention ............................. 48

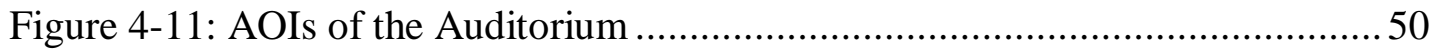

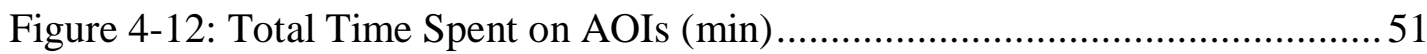


Figure 4-13: \% of Total Time Spent on AOIs ................................................. 51

Figure 4-14: \% of Total Time Spent on the AOIs (front and back) .........................52

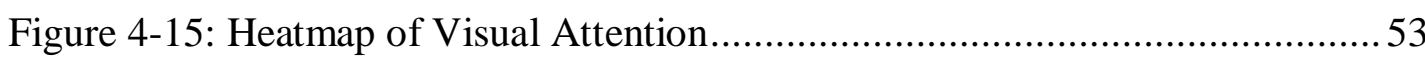

Figure 4-16: \% of Total Time Spent on Back and Front in the 1st Part of the Course .54

Figure 4-17: \% of Total Time Spent on the AOIs .............................................55

Figure 4-18: \% of Total Time Spent on the Front and Back ..................................55

Figure 4-19: Heatmap of Visual Attention Across the Middle and Right ................ 56

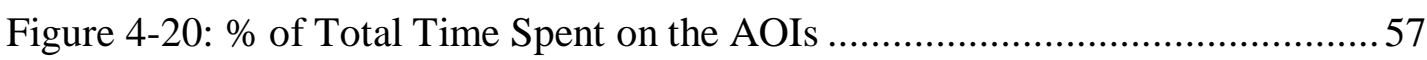

Figure 4-21: \% of Total Time Spent on the Front and Back................................. 58

Figure 4-22: Heatmap of Visual Attention Across the Middle and Right ................58

Figure 5-1: Comparison of the 2nd Participant's Heatmaps on the AOI (Middle Area) 73

Figure 5-2: Comparison of the 2nd Participant's Heatmaps on the AOI (Right Area) 


\section{CHAPTER 1}

\section{INTRODUCTION}

Classroom management $(\mathrm{CM})$ composes of the techniques teachers use to control the class and provide effective teaching with students, which makes the skill a requisite for the teachers. Teachers have many roles in a classroom, however; one of the most significant roles teachers need to have is classroom manager because effective learning and teaching can consist of a well-managed classroom (Marzano \& Marzano, 2003). That is to say, the better the classroom management is, the more effective the teaching and learning are. Moreover, $\mathrm{CM}$ gives a considerable contribution to the acquisition of knowledge in classroom environments (Elias \& Schwab, 2006). Classroom management strategies have a significant impact on supporting and facilitating effective teaching and learning (Wubbels et al., 1999). As a result, CM is one of the critical factors for effective teaching and learning.

In classroom management, using non-verbal communication techniques effectively has a significant impact on student's learning. Eye contact is the crucial one among non-verbal communication techniques (Zeki, 2009). In Zeki's study, it is suggested that teachers are aware of non-verbal behaviors for a better teaching and learning environment. However, especially in higher education institutions, many faculty members are not equipped with pedagogical information. Therefore, many of them have insufficient knowledge about classroom management strategies such as eye contact and gestures. In the Khan et al. (2016) study, it was reported that an eye contact training programme is needed in high level education system. Also, in the study, it is recommended that instructors participate in training programs related to the use of non-verbal communication strategies such as eye contact. In the Jerez et al. (2016) study, most of the professors stated that the most important problem they have encountered is communicating with the students. Some professors reported that they 
do not know how to cope this problem. Also, some of them criticized that assessment methods like peer evaluation are not as effective as they should be. Moreover, Jerez et al. (2016) consider that technological advances provide us with great opportunities to improve communication skills of faculty members, but they think that they are not used effectively inside classroom medium. Therefore, the main objective of the current study is to show how a wearable eye tracker can be employed in a real-world classroom environment to assess and improve the faculty members' classroom management by addressing their visual attention. The current study aimed at assessing and improving especially eye contact skill of the faculty members by a wearable eye tracker. Furthermore, by video camera records, the current study also attempted to change some behaviors of the faculty members about their gestures while they were lecturing.

The recent studies represented that eye-tracking technology can be used as a tool to assess individuals' performance and improve their skills by studying visual perception in the fields such as surgery, and aviation (Tien et al., 2014; Muehlethaler \& Knecht, 2016; Sánchez-Ferrer et al., 2017). However, the number of studies in which eyetracking method is employed in a real-world classroom environment is very few. Accordingly, the current study may make significant contribution to the literature.

\subsection{Background of the Problem}

In the literature, there is a general view; teachers and their classroom management skills are necessary for effective teaching and learning. Thus, there is various research related to classroom management and evaluation of teaching performance. Though, it is still desired for researchers to explore classroom management perceptions of teachers and contribute to improving their classroom management skills because in a well-managed class, an efficient learning and teaching occur (Marzano, Pickering, \& Marzano, 2003). Besides, teachers play a crucial role in students' achievement (Sanders, Wright, \& Horn, 1997). However, especially in higher education, most teachers have difficulty in creating effective teaching and learning environment for 
their students because many of them do not have pedagogical information about the teaching profession. It is stated that in most countries, many academics do not need to have a teaching qualification or get training about teaching (European Commission, Eurydice, \& EACEA, 2018). Therefore, assessing teacher performance and giving feedback about classroom management becomes even more critical. Many universities prefer using different methods to evaluate and improve teaching quality (European Commission et al., 2018). The most commonly used technique to assess teaching is student feedback survey. However, the reliability of student feedback survey is argued (Gaebel \& Zhang, 2018). Also, Gaebel and Zhang asserted that institutions surveyed under the Trends 2018 are not pleased with the present methods in assessing teaching quality, and they want to improve them. Consequently, applying new methods to train faculty members and share informative feedback about their classroom management can positively affect teaching quality.

In classroom management, non-verbal communication techniques such as eye contact and gestures play a crucial role in university students' learning as well as K-12 students' learning. Therefore, improving faculty members' ability of using non-verbal techniques can enhance teaching quality in higher education institutions. According to Zeki (2009), non-verbal behaviors including gestures and eye contact can be employed to control classroom and keep pupils quiet in K-12 level. However, university students perceive non-verbal behaviors such as eye contact differently; university students generally consider eye contact as a source of motivation and passion. Also, they perceive it as a sign for maintaining their concentration and attention. Cognitive scientists claimed that students can learn when teachers become successful to draw students' attention to the topic because information processing starts with drawing students' attention to the topic (Cruickshank et al., 2003 cited in Zeki, 2009). According Hsu (2010), using eye contact technique properly is one of effective teaching attitudes. Eye contact occupies a vital place in classroom management. Therefore, training faculty members about the use of eye contact technique can make positive contribution to their classroom management 
performance. In the Jerez et al. (2018) study, professors had difficulties in communicating with their students. The authors are asking "why are not technological tools used to improve their communication skills?". Eye-tracking technology can contribute to the enhancement of faculty members' communication skills because it can share useful information about their visual perception in classroom environment. Thereby, it is possible for faculty members to receive feedback about the use of communication strategies such as eye contact by a wearable eye tracker, which can have positive impact on their classroom management.

Limited number of studies showed eye-tracking technology can be used to study visual attention of teachers. In the Van den Bogert et al. (2014) study, for instance, the researchers compared the experienced and novice teachers' visual attention and interpretation of classroom events by using eye-tracking technology. The results of the study showed that eye-tracking methodology could be an effective method to study teachers' visual attention, and it can also be used in the dynamic classroom environment. Moreover, in the study, it is stated that eye-tracking can help the researchers to understand teachers' insights and cognition that are not extracted in the interviews. Similarly, in the Yamamoto and Imai-Matsumura (2012) study, eyetracking methodology was employed to investigate the gaze patterns of the teachers while they were watching the video of a lesson. This study also compared the teaching experience of novice and expert teachers. The results showed that teachers who were aware of the students' misbehaviors fixated on the students more often and longer than those who were not aware of the misbehaviors. Also, the study suggested that teaching experience and being aware of the students' negative behaviors is not related to each other. Consequently, the study revealed that an eye-tracking methodology is a tool that allows the researchers to study visual perception of teachers. Regarding the types of eye tracker that was used in these two studies, screen-based eye trackers were used. However, screen-based eye trackers limit the participants and stimuli, creating main problems for naturalistic viewing studies, in contrast; with wearable eye trackers, it is possible for the researchers to record gaze points of the participants who freely move 
in an environment and have the interaction with the real-world stimuli (MacInnes et al., 2018). Similarly, in the Yamamoto and Imai-Matsumura (2012) study, while teachers were watching a video, their gaze was studied by a screen-based eye tracker. The authors consider that this is not the same as observing teachers' fixations while they are teaching in real-world classroom environment. Therefore, in the current study, it was thought that a wearable eye tracker would be the best suitable technology to study teachers' visual attention in a real-world classroom environment. For instance, McIntyre, Mainhard and Klassen (2017) showed that a wearable eye tracker could be employed in real-world classroom environments to investigate cultural, temporal and dynamic insights into an expert teacher. In short, in the literature, there are some studies in which eye-tracking methodology was used to investigate the teachers' visual attention, and to compare novice and expert teachers' gaze patterns, however; it is hardly seen that wearable eye-tracking technology is used to improve visual attention in real-world classroom environments. Therefore, the main focus of the current study is to make it clear that if eye trackers (mainly wearable ones) can be employed to contribute to the development of the faculty members' classroom management by addressing their visual attention. Secondly, it attempts to show how wearable eye-tracking technology can be used in real-world classroom environments to improve the distribution of the faculty members' visual attention across the students and other classroom materials.

\subsection{Statement of the Problem}

The literature has many studies evaluating teachers' classroom management performance by using the methods, including survey, observation, and interview. On the contrary, it is seen in the literature that there are very few studies evaluating their classroom management skills with wearable eye-tracking methodology in real-world classroom environments. Though, a systematic review (Tien et al., 2014) showed that eye-tracking methodology can be employed as an assessment and training tool. This study concluded that eye-tracking is a promising field of research. This study also showed that there needs more research that demonstrates the capability of eye-tracking 
as a training tool. Thus, there is a need to investigate how wearable eye-trackers can be employed as an assessment and training tool in real-world classroom environments.

\subsection{Purpose of the Study}

There are considerable evidence indicating eye-tracking is one of the useful methods which are successful to assess and improve the human performance in the fields such as aviation (Muehlethaler \& Knecht, 2016; Weibel et al., 2012), surgery (SánchezFerrer et al., 2017; Chetwood et al., 2012), sports (Wood \& Wilson, 2011) and driving (Borowsky, Shinar, \& Oron-Gilad, 2010). There are also some studies demonstrated strong evidence that eye-tracking could be a useful tool to evaluate and improve teachers' classroom management skills by focusing teachers' visual attention (Van den Bogert et al., 2014; Wolff et al., 2016; Yamamoto \& Imai-Matsumura, 2012). Concerning this, Weibel et al. (2012) stated that eye-tracking plays a significant role in evaluating expert human performance since it allows the researchers to observe and analyze where to fixate, when to fixate and what to see while they are working on tasks. Considering these studies, the objective of the current study is to demonstrate if it is possible to use eye-tracking method in real-world classroom environments to improve the faculty members' classroom management skills by concentrating their visual attention. This study also aims at showing how the faculty members' classroom management performance can be evaluated by wearable eye trackers in real-world classroom environments.

\subsection{Significance of the Study}

Eye-tracking technology is widely used as a tool to assess and improve human performance. Eye-tracking studies, for instance, can be found especially in the fields of medicine (Breen, Bond, \& Finlay, 2014), aviation (Glaholt, 2014) and sport science (Grushko \& Leonov, 2014). The recent advances in wearable eye-tracking technology (known as mobile eye trackers) have allowed researchers to do more research to assess and improve human performance in a real-world environment. However, there are 
very few studies on the use of eye-tracking to investigate the visual attention of teachers in real-world classroom environments. It is stated that visual attention has been investigated in many professions, but research on teacher's viewing behaviors is too few (Wolff, Jarodzka, \& Boshuizen, 2017). Therefore, the current study may have a significant place in the literature. Moreover, there are some criticisms on the teacher evaluation system of the universities, so some universities are seeking methods that will effectively assess teaching performance and share constructive feedback about it. There is a relationship between classroom management and teaching performance. Thus, improving faculty members' classroom management skills can positively affect their teaching performance. Furthermore, in classroom management, faculty members' viewing behaviors has a facilitating effect on students learning (Zeki, 2009). Therefore, this study may make it possible for universities to use wearable eye trackers to evaluate classroom management and share meaningful information about it. That is, this study may contribute to innovative teaching. Furthermore, teachers play a very critical role in students' achievement and, so it is thought that teacher performance is one of the essential determinants affecting academic success. Therefore, improving teacher quality means educational improvement as teachers have a leading role in the education system (Hopkins \& Stern, 1996). In view of such information, the current study may make a considerable contribution to educational improvement, since it may contribute to the field of education by clarifying if it is possible to use wearable eye trackers in a real-world classroom environment as a feedback tool respecting classroom management. Another reason for this study is to build a clear understanding regarding the implementation of wearable eye-tracking technology in the aim of assessing classroom management skills. Many researchers have conducted plenty of research on the importance of teachers and classroom management. The evaluation methodologies used by most of these studies mainly consist of surveys, interviews, and observations. In contrast, it is hardly found that wearable eye-tracking technology is employed for the evaluation of teachers' classroom management skills in real-world classroom environments. Consequently, this study can make it clear for researchers 
and educators to understand how wearable eye tracker can be used as an assessment and training tool in real-world classroom environments.

\subsection{Assumptions}

The current study assumes that:

- The participants took part in the study voluntarily,

- The participants answered the interview questions honestly and accurately,

- The eye-tracking data were recorded and analyzed accurately,

- Teaching experience level of the participants were the same,

- The instruments used in the study presented reliable and valid measurements,

- The instruments and processes have a degree of applicability and generalizability to schools and higher education institutions.

\subsection{Research Questions}

In this study, to investigate the effect of wearable eye tracker on the enhancement of instructors' classroom management skills, it intended to answer the question below.

How can wearable eye trackers be employed in real-world classroom environments as a training and assessment tool to improve faculty members' classroom management skills?

\subsection{Limitations}

In the current study, the wearable eye tracker employed may have affected the teachers' actual performance. In the study, the teachers are aware of that their eye movements were watched and analyzed during the study so they may have tried to show their best performance during the study. Another limitation is that teachers have been irritated by the wearable eye tracker. During approximately 45-minute-lesson, faculty members had to wear mobile eye tracker (MET), and it is known that over long 
periods of the time, wearing MET can disturb the participants. In the current study, when this problem occurred, changing the nose pad of the eye tracker was proposed.

\subsection{Delimitations}

This study confines itself to the investigation of the faculty members' classroom management skills using wearable eye-tracking technology. The faculty members are experienced, working as academic personnel for more than ten years at a university in Turkey.

\subsection{Definitions of Term}

Classroom Management (CM): Classroom management consists of the techniques. Teachers, educators or faculty members uses these techniques to create an effective teaching and learning environment.

Wearable Eye Tracker or Mobile Eye Tracker: It is a product of wearable technology, and it looks like glasses. That is, it is a head-mounted system; in real-world environment, it captures eye movements and gives valuable data about them.

Screen-based eye tracker: It is mounted at the bottom of computer screen and it captures eye movements on the computer screen.

Eye-tracking: It is a technique that was done by eye trackers, including screen-based eye trackers and wearable eye trackers.

Retrospective Think Aloud (RTA): It is a way to learn participants' thoughts. Participants are expected to think aloud while they are interpreting their eye movements, which makes it easy for researcher to understand relationship between their thoughts and visual attention. 



\section{CHAPTER 2}

\section{LITERATURE REVIEW}

It is a known fact that teachers play a decisive role in students' academic success. When the responsibilities of teachers are taken into consideration, teachers are expected to get students to the possible top level of accomplishment (Chandra, 2015). Thereby, it is undeniable that teacher performance is one of the most determining factors influencing student achievement. Concerning this, Goldhaber (2002) states that teacher effectiveness has more impact on student achievement than any other schooling factors. There are important factors identifying effectiveness of teachers, but productive classroom management is the crucial one and essential job teachers need to do because effective teaching and learning cannot happen in poor classroom management. In the light of this information, the issue of teacher education and teacher training burst into prominence. In this regard, some studies showed that there is an urgent need to improve teacher preparation programs (Ball \& Forzani, 2009; Grossman, Hammerness, \& McDonald, 2009). Hence, in conjunction with technological advancements, some new techniques have been applied to teacher preparation recently. Kaufman and Ireland (2016) suggested that teacher preparation programs need new approaches to make teachers ready for future difficulties. According to them, simulation could be a good fit for this purpose. Similarly, eyetracking technology has recently become a valuable tool to assess human performance and improve skills in education. The examples can be found in airport security (Liu \& Gale, 2007), surgery (Diaz-Piedra et al., 2017) and maritime (Sanfilippo, 2017). To conclude, the purpose of this section is to review the research literature to show the importance of classroom management in universities. This section also gives information about training of faculty members and evaluation of their teaching. Of course, the purpose of this section is to profoundly investigate the literature to be able 
to show how eye-tracking methodology can be used as a training and assessment tool in the educational sciences as well as the other research fields.

\subsection{Teacher Effectiveness}

It is widely accepted that every teacher has a straight impact on students' achievement. Therefore, the effectiveness of teachers is a crucial element to raise up students' success. One study (Heck, 2009) aimed at investigating teacher effectiveness and student success. The results showed that the effectiveness of the teachers has an impact on student achievement. Similarly, the results of a study by Clotfelter, Ladd, and Vigdor (2006) indicated that there was a positive relationship between student success and teacher qualifications. So, what makes a teacher effective? This question has been argued over long periods, and it is still open to be discussed. Thereby, it is tough to give a specific answer to this question. However, effective teachers can be thought as those who make learning possible and straightforward. Ramsden (1992) states that "the aim of teaching is simple: it is to make student learning possible...To teach is to make an assumption about what and how the student learns; therefore, to teach well implies learning about students' learning" (p.124). Classroom management is one of the decisive factors affecting teacher effectiveness. Therefore, evaluation of faculty members or teachers' CM performance play a fundamental role in creating effective teaching environment. The following sections attempted to explain the significance of classroom management and give information about evaluation of educators' CM skills.

\subsubsection{Classroom Management in Higher Education}

Classroom management is a vital issue in higher education as well as in K-12. According to Al-Hamdan (2007), classroom management plays a vital role in university education. However, in higher education institutions, classroom management and teaching can be more problematic. Many higher education teachers do not have enough knowledge about classroom management as they do not get 
pedagogic formation about the teaching profession, so they can fail to provide students with productive learning environment. In the Ganser (2001) study, the faculty members stated that they frequently encountered two most common problems: poor classroom management and insufficient resources. According to Etheridge (2010), faculty members receive insufficient training about classroom management, so they try to manage classroom with their personal characteristics. Seeman (2009) consider that in universities, disruptive behaviors of students have become one of the main problems in recent times. He thinks that this creates a negative effect on not only students but also professors. Most importantly, many university teachers do not have enough information to overcome disruptive behaviors in college classrooms. According to him, before K-12 teachers are hired, institutions request them to acquire knowledge about classroom management and teaching methods. However, before college teachers are hired, universities focus on topic knowledge respecting their expertise; many universities do not request college teachers to be equipped with pedagogical skills. Similarly, Meyers (2003) claimed that instructors have insufficient information about how to cope with classroom management problems. Likewise, Jawaharlal (2017) asserted that many professors have insufficient knowledge about teaching and classroom management. Besides, in the Bologna Process Implementation Report, it was reported that in many countries, higher education teachers are not expected to have teaching qualifications or get training about teaching. They are demanded by law, especially when academic ranks are foremost (European Commission, EACEA \& Eurydice, 2018). Furthermore, in Henderson's study (2016), disturbing behaviors in the classroom among students can severely affect learning because the instructors stop teaching and focus on the behaviors. More importantly, in this study, the instructors defined that they have insufficient knowledge about how to cope with these behaviors among the students and they agreed that training should be regularly given to them about this issue. As a result, as teachers in higher education have inadequate pedagogical knowledge about teaching, it is crucial for institutions to develop formal facilities for teachers to show their teaching performance and give meaningful feedback about it (Vieira \& Neto, 2016). In higher education, instructors 
have to manage the classroom better because they teach in larger classroom size such as auditorium. For this reason, they need to be equipped with the necessary skills for classroom management. Accordingly, establishing an effective teaching and learning environment can turn into a nightmare for instructors who have not got enough knowledge about classroom management strategies. Jerez et al. (2018) conducted a study to investigate the challenges professors are faced with while managing large group activities in universities. Fifty professors coming from eight different Chilean universities participated in this study, and the professors were teaching in the fields such as health, education, business, and social sciences. The results of this study showed that the most common problem is the implementation of effective communication; the professors have difficulties in staying connected to the students. In addition, the authors stated that there are technological tools that provide us with innovative methods to enhance faculty members' communication skills. However, they think that technological tools are neglected. Another important finding of this study is related to the evaluation system; the professors complaint about peer instruction and peer evaluation. They criticized that assessment strategies are not enough. The other significant problem the professors confronted is about creating a learning environment; they defined that it is challenging for them to create a learning environment in larger groups. On the other hand, classroom management can be a problematic issue for teaching assistants as well because most of them are not equipped with pedagogical knowledge, especially about how to cope with classroom management. According to Luo, Bellows and Grady (2000), many teaching assistants encounter more classroom management problems, especially at the beginning of their careers. In the Luo et al. study, it was implied that by employing training programs, teaching assistants should be equipped with the necessary knowledge that will help them to overcome classroom management problems. In the Al-Hamdan (2007) study, it was recommended based on the study's findings that special training programs are organized for new faculty members. Moreover, it is suggested that experienced faculty members get training to develop and upgrade classroom management skills. Similarly, Ladeji-Osias and Wells (2014) assert that classroom management has become one of 
the important matters in the engineering field. They imply that faculties should develop practices to build an effective teaching and learning environment.

To conclude, in higher education institutions, classroom management is one of the problematic issues. Faculty members need training about classroom management as they do not have enough information to manage classroom. The literature also shows that new methods are needed to improve faculty members' classroom management skills.

\subsubsection{Evaluation of Teaching in Higher Education}

Creating an effective teaching environment could be challenging for many university instructors. The main reason for this is that instructors in universities do not receive pedagogical training. Today, this became one of the important issues in university education. According to Henard and Roseveare (2012), higher education can be no longer considered as a society of disciplinary experts who provides students with knowledge. Complex and uncertain conditions in society and economy forces higher education institutions to adapt to new circumstances while keeping quality standards. Institutions have to find the finest way that will serve the students. Students are now in the center of the learning approach across the world. Henard and Roseveare (2012) proposed that the role of the university is altering. Therefore, instructors are expected to have effective pedagogical skills for learning outcomes. Moreover, the researchers considered that the instructors are expected to upgrade their pedagogical abilities as well as professional development to increase the quality of teaching. The researchers also proposed that in order to advance instruction's quality, instructors' performance needs to be improved by peer-evaluation and constructive feedback. Similarly, Brown and Atkins (2002) claimed that effective teaching includes a group of skills that can be enhanced, obtained, and extended. They highlighted the importance of observing, developing, and evaluating instruction for effective teaching in higher education. According to Bloom (2008), teachers are a learner. They can develop their classroom practices by evaluation methods. Likewise, in European University Association's 
Report (2019), higher education institutions should suggest methods for feedback and self-improvement. In the Trends 2018 report, it is asserted that the instructors' performance is assessed frequently in higher education institutions, yet assessment tools are still being investigated. (Gaebel \& Zhang, 2018).

Regarding the evaluation of teaching in higher education, many universities, today, prefer student evaluation to assess teacher performance. According to the Bologna Process Implementation Report (as cited in EUA, 2018), student feedback is the most common way that is used to evaluate teaching performance, and other ways are less commonly used (see Figure 2-1) (European Commission, EACEA \& Eurydice, 2018).

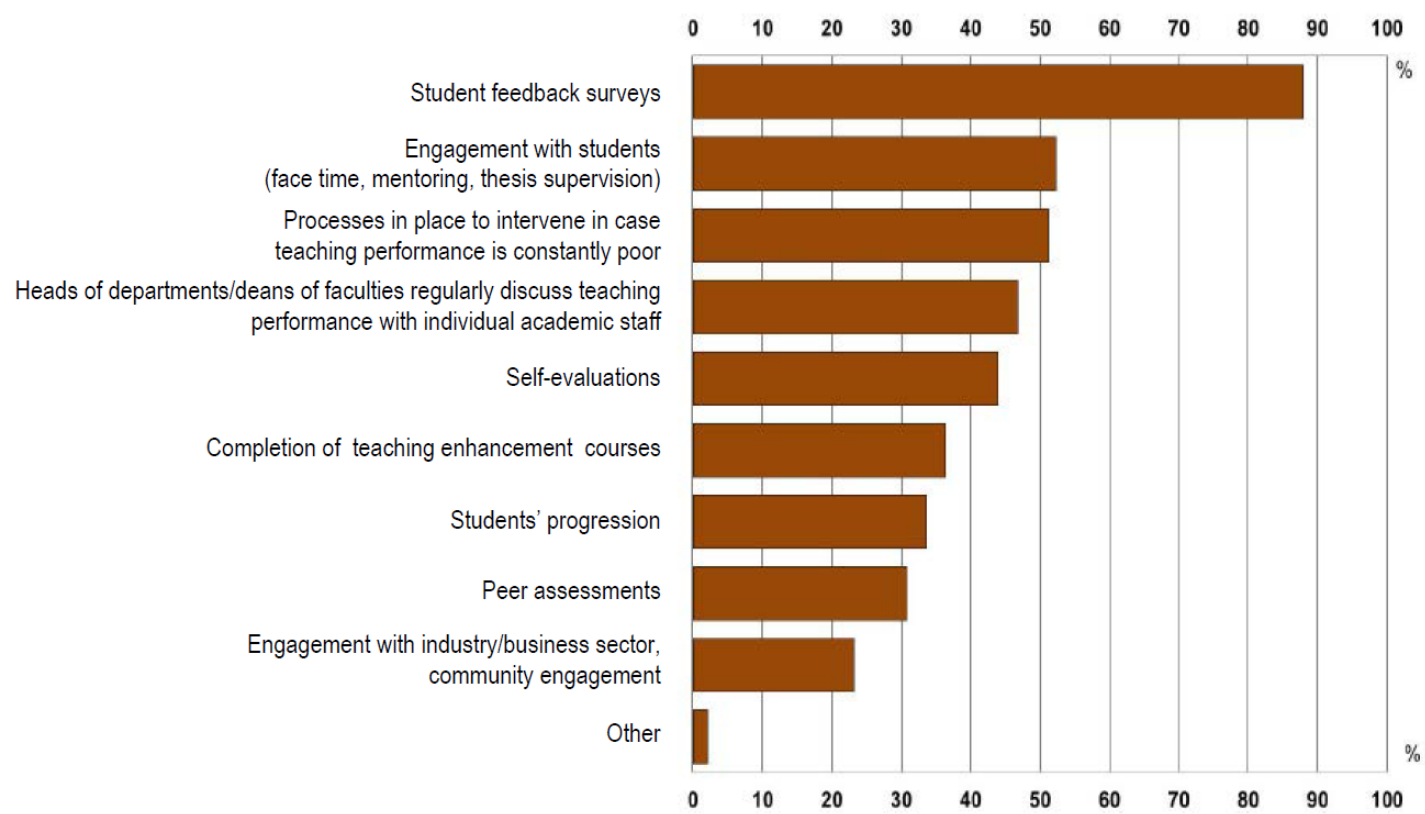

Figure 2-1: Ways of Evaluation of Teaching Performance (\% of institutions)

(European Commission et al., 2018 as cited in EUA, 2018, p.88)

However, on the subject of assessment done by students, there are some important criticisms of course evaluations. According to Salomons and Goos (2014), course evaluation is widely employed by universities to measure teaching quality, but the answer to course evaluations is biased. The authors asserted that this bias comes from the choice of the features that are not possible to be observed by the classic university administrator. Similarly, Kulik and McKeachie (1975) claimed that feedback from the 
student evaluations does not provide a considerable benefit to teachers; according to them, the research outcomes recommend that there is no single method to assess teaching skill. Besides, the researchers suggested that procedures that are beneficial for the administrators may not help teachers to improve their performance. Furthermore, Hénard (2009) considered that because of the continuous growth and variation of higher education systems, the concern of society about the quality of programs which is offered to students is increasing. In Hénard's study, one of the suggested implications that will improve the quality of teaching is to develop new measurement and assessment methods. Likewise, as one of the higher education policy themes (OECD, 2017), it is significant for higher education institutions to develop strategies to improve learning and teaching. In this way, higher education teachers can teach a large mass of students. Moreover, assessing teaching in higher education can increase the quality of instruction because faculty members get informative feedback about their instruction. Therefore, teaching assessment and feedback for teaching play a key role in improving learning outcomes. Accordingly, Schleicher (2015) proposed that sharing constructive feedback with faculty about the teaching quality should be the main purpose of the evaluation of higher education learning outcomes.

\subsubsection{Training Higher Education Teachers}

Educating instructors about the teaching profession has become one of the important issues in recent times. Therefore, training instructors has become a widespread topic in many universities across the world (Postareff et al., 2007). Some studies showed that pedagogical training for instructors has positive impacts (Coffey \& Gibbs, 2000; Ödalen et al., 2019). The reason why training instructors is a significant issue is that training university teachers on teaching professional has a positive impact on student learning. In Gibbs and Coffey's study (2004), the efficiency of instructors' training was investigated. The result of the data indicated that training could enhance instructors' teaching skills, so student learning can be improved. Consequently, 
teaching quality plays a key role in the quality of higher education institutions (Üstünlüoğlu, 2017).

In the Bologna Process Implementation Report, it is stated university teachers play a crucial role in the student achievement, and higher education teachers are also requested to acquire teaching skills by employing suitable training before they are hired. In the report, however, it is claimed that many regulations do not need higher education teachers to have a good teaching ability, and the enhancement of teaching qualifications is often neglected. Furthermore, the Bologna Process Implementation Report (as cited in EUA, 2018) showed that only $25 \%$ of higher education institutions give systematic training to all higher education teachers. In nearly $40 \%$ of higher education institutions, instructors can take training when they demand it. $13 \%$ of them do not offer any training to teachers. Consequently, universities mostly present optional training programs that aim to improve teaching skills. Other ways to enhance teaching skills such as necessary teaching courses and peer feedback are not common. (European Commission, EACEA \& Eurydice, 2018) (see Figure 2-2). Furthermore, in European University Association's report (2019), it is stated that evaluating and improving teaching proficiency in higher education is one of the most difficult tasks. The report also highlights the significance of investing the support that contributes to teaching development. In addition to this, Jawaharlal (2017) asserted that many professors want to help students to learn, but they don't know how to teach. According to Jawaharlal, in many higher education institutions, new faculty members who haven't participated in teacher training programs are expected to teach courses since teaching quality is not their prime purpose. Comparably, scholarship and research play a more important role in evaluating instructors' qualifications rather than their teaching performance. Many distinguished universities do not pay attention to teaching quality. In these universities, graduate students who haven't got any teacher training or have little information about teaching generally teach courses (Hanc, 2016). In the Henderson (2016) study, it is recommended that new faculty members participate in training sessions before starting to teach. Therefore, they will learn 
strategies to cope with misbehaviors students perform in classroom environment. In the Khan et al. (2016) study, it is suggested that instructors are trained about the use of non-verbal behaviors for effective classroom management.

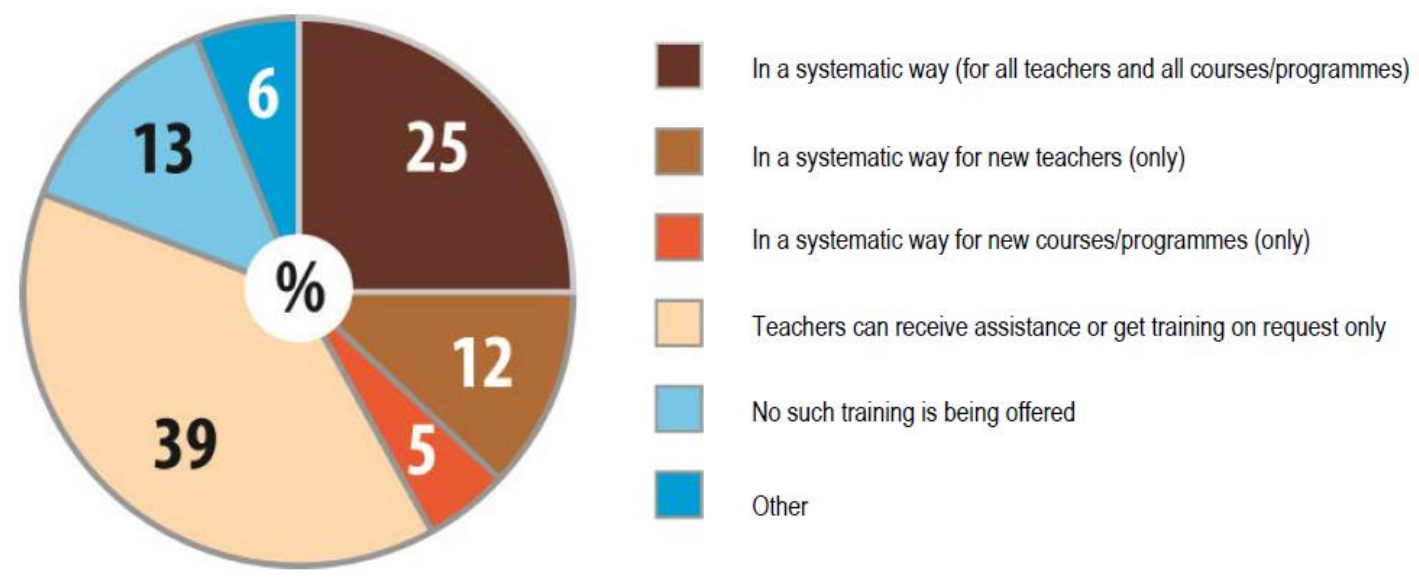

Figure 2-2: \% of Universities Training Faculty Members

(European Commission et al., 2018, as cited in EUA, 2018, p.58)

However, teaching quality is still one of the important topics for some higher education institutions, so Teaching and Learning Centers (TLCs) has come to the fore in these universities. According to Trends 2018, in Europe countries, the number of TLCs has increased in recent times (Gaebel \& Zhang, 2018). The main objective of TCLs is to improve the teaching quality of universities and support student learning. To improve teaching quality, TLCs provide consultation services with faculty members and organize seminars about effective teaching. In addition to this, they train new faculty members about teaching methods, classroom management, and instructional technology to support the development of an effective teaching environment in universities (METU Center for Advancing Learning and Teaching, 2019). In addition, Instructional Technology Support Centers (ITS Centers) have been established in many universities to create an effective teaching and learning environment since the use of instructional technology in universities has considerably increased for nearly a decade. The purpose of ITS Centers is to support faculty members about the use of instructional technology, so they can enhance their teaching 
and student learning (Çağıltay et al., 2007; Gürbüz et al., 2008; Akteke-Öztürk et al., 2008; Çă̆ıltay, 2011).

\subsection{Eye-Tracking}

Eye-tracking is a beneficial technique for those who want to study human behaviors. Researchers, scientists, and professionals can gain insight into human behaviors by utilizing eye-tracking technique as this method gives them a possibility to observe where an individual is looking at. This is because there is a close relationship between eye movement and human behavior. Similarly, Poole and Ball (2006) considered eyetracking as a technique, with which eye movements of the individuals can be measured. Thus, it enables eye-tracking researchers to observe where a person is looking at any given time and the sequences of eye movements.

According to Poole and Ball (2006), eye tracker is a device that captures eye movements and calculates eye movements metrics like fixations, saccades, and regressions using Pupil Center Corneal Reflection Method. Today, there are two different eye-tracking systems that are employed by researchers: screen-based eye trackers (also known as stationary eye trackers) and wearable eye trackers (also known as mobile eye trackers). In eye-tracking studies, if a stimulus is needed to be displayed on the monitor, projector or TV screen, then a screen-based eye tracker can be a suitable tool to track eye movements. Screen-based eye tracker can be mounted on the bottom of the display via magnet or put in front of the display via tripod. However, this type of eye tracker is not practical in naturalistic viewing studies because they limit the human behaviors to the display. On the other hand, wearable eye trackers are the most suitable ones in tracking the participants' eye movements in their naturalistic environments since wearable ones allow participants to move freely in the real-world environment. Today, some of the commercial eye trackers look like glass (see Table 2-1). Since wearable eye-trackers make it simple for the researchers to study naturalistic viewing behaviors, they are more favorable comparing to screen-based 
ones. Also, they enable eye-tracking researchers to study with new contexts and new subject populations (MacInnes et al., 2018).

Table 2-1: Commercial Wearable Eye Trackers

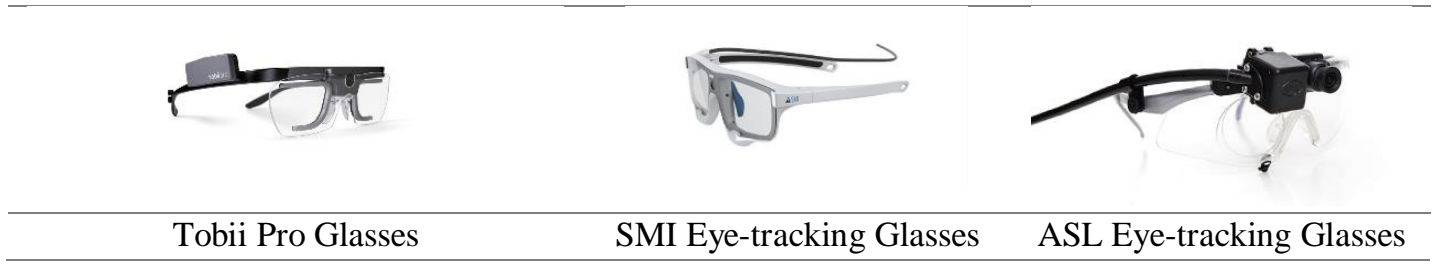

\subsection{Eye Contact and Gestures in Classroom Management}

In classroom management, non-verbal behaviors such as eye contact and gestures are as crucial as verbal behaviors (Lemmer, Meier, \& Van Wyk, 2012). According to Ledbury, White, and Darn (2004), verbal communication is just one part of classroom management techniques. Therefore, instructors should be trained about the use of nonverbal strategies (Khan et al., 2016). Especially eye contact is crucial one among the non-verbal communication techniques (Barati, 2015). It is so useful for both teachers and students. Therefore, using eye contact correctly have a positive impact on student learning (Ledbury et al., 2004). Furthermore, in the Hains-Wesson (2011) study, 91\% of university students who participated in the survey agreed that eye contact was helpful to gain their attention. Moreover, $74 \%$ of them agreed that eye contact helped them to be more passionate about the topic. Similarly, in the Zeki (2009) study, university students see eye contact as a cue for maintaining their concentration and motivation. Also, the author recommended that teacher comprehend the significance of non-verbal behaviors, especially eye contact that have a worthwhile effect on classroom management. Hodge (1971) stated that eye contact assists teachers to affirm students' existence, which upraises student motivation. Moreover, according to Hsu (2006), using non-verbal communication techniques properly is one of the effective teaching attitudes. In the Yarbrough and Price (1981) study, the data showed that there was a strong correlation between eye contact and on-task behavior of the students. Consequently, it is vital for educators to use non-verbal communication methods 
correctly because there is a strong relationship non-verbal behaviors and student learning (Christophel, 1990).

\subsection{The Relationship Between Eye Movements and Human Behaviors}

Many studies indicated that eye movements and human behavior are closely related. Therefore, eye-tracking method offers valuable data to the researchers in understanding human behaviors. According to Tatler et al. (2014), eye movements offer reliable data in understanding the ongoing cognitive process. Also, a wide range of research disciplines shows that eye movements help us to understand types of human behavior. Furthermore, utilizing eye-tracking makes it plain for researchers to study the relationship between visual perception and action. A review study showed that there is a link between eye movements and perception (Schutz, Braun, \& Gegenfurtner, 2011). Besides, Tatler et al. highlighted the significant role of perception while we're operating in the world around us. According to them, comprehending the environment will give us beneficial information in performing the task which we engage in. Similarly, Hommel et al. (2001) recommended that visual attention and action is the "functionally equivalent." On the other hand, Tatler et al. suggested that if we want to study the link between perception and action, it should be performed in the context of natural attitudes that are exhibited in the real-world environment. To conduct this study, the authors considered mobile eye-tracking devices as a proper fit since these devices allow eye movement records to be made in a real-world environment. Moreover, they claim that wearable eye-tracking technology has not only enabled the researchers to study natural viewing attitudes but has also brought prominent insights into the correlation between vision and action on which has not been recognized before.

To sum up, eye movements are one of the most critical research data to understand human behavior. Tatler et al. (2014) support this claim; according to them, eye movements offer strong research tools to those who wish to study the types of human behavior and cognition. As a consequence of that, they suggested that eye-tracking 
gains popularity in a wide range of discipline fields and among those who are interested in the studies of human behavior.

\subsection{Eye-tracking as a Training and Assessment Tool}

Recent studies show that eye-tracking methodology could be employed in many research disciplines as a training and evaluation tool. By using wearable eye trackers, researchers, educators, and trainers find the opportunity to assess the performance of the participants from various fields in their natural environment. As a result, surveying the recent studies indicates an increment in the utilization of eye-tracking as a training and assessment tool. These studies were carried out in the various disciplines such as field of medicine and surgery (Al-Moteri et al., 2017; Chetwood et al., 2012; DiazPiedra et al., 2017; O’Neill et al., 2011; Sánchez-Ferrer et al., 2017; Vine et al., 2012; Wilson et al., 2011), aviation and maritime (Muehlethaler \& Knecht, 2016; Liu \& Gale, 2007; Sanfilippo, 2017; Van De Merwe et al., 2012; Weibel et al., 2012), civil engineering (Jeelani, Han, \& Albert, 2018), and sport science (Moore et al., 2012; Vine \& Wilson, 2010; Wood \& Wilson, 2011). As mentioned above, the literature presented a multitude of studies employing eye-tracking method as a tool to assess individuals' performance as well as improve their skills. On the contrary, in the literature, there is an insufficient number of studies where the eye-tracking methodology was adopted so as to assess and improve the instructors' classroom management skills. The next section briefly describes these studies.

\subsection{Eye-tracking for Assessing Teachers' Visual Attention}

With the advancement in wearable eye trackers, the use of eye-tracking has become one of the most effective tools in training individuals and improving their performances in the fields such as aviation, surgery, sports sciences, etc. This made it possible for educational researchers, and educators to employ the eye-tracking method in a real-world classroom environment to evaluate teachers or faculty members' performance and improve classroom management skills. Yamamoto and ImaiMatsumura (2012) employed an eye-tracking method to investigate the gaze behaviors 
of the teachers. In this study, 43 Japanese elementary teachers participated, and they were divided into the groups depending on their teaching experiences. With the help of a screen-based eye tracker, the teachers' eye movements were measured while they were watching a video of a lesson. The results of the study concluded that there is no significant difference between teaching experience and the ability to notice students' misbehaviors. However, according to Yamamoto and Imai-Matsumura, this study indicated that eye-tracking is an effective tool showing the cognitive process of teachers. In a similar study conducted by Van den Bogert et al. (2014), the researchers used a screen-based eye tracker to investigate teachers' visual attention and the identification of classroom events. Twenty experienced secondary school teachers and twenty teacher candidates (novice) were asked to take part in the study. The participants were requested to press a button when they observed any classroom event or precursor while they were watching a video of the lesson that was recorded with the teachers' perspective. At the same time, eye movements of the participants were tracked and measured by an eye tracker. The study had positive results in terms of the use of eye-tracking methods in teacher education. Firstly, Van den Bogert et al. (2014) showed that experienced teachers could more evenly fixate on pupils, compared to student-teachers (see Figure 2-3).

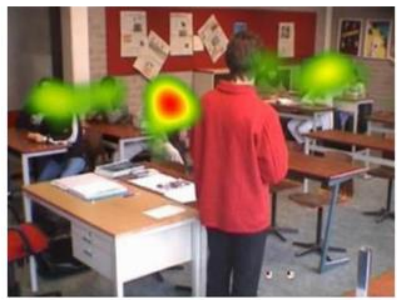

Novices

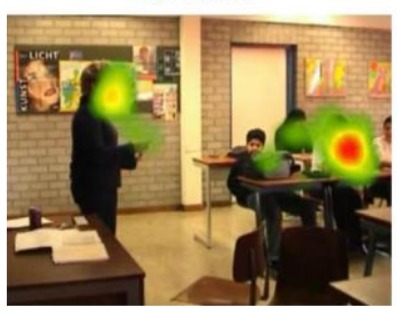

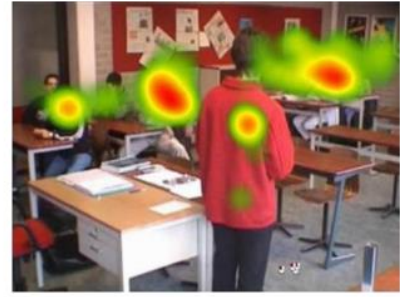

Experts

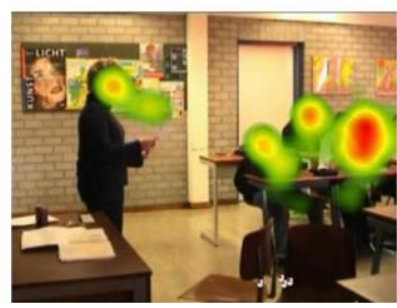

Figure 2-3: Heatmap of Novice and Expert Teachers' Glances (Bogert et al., 2014, p.213) 
Secondly, the study concluded that novice teachers concentrated on defects; while experienced teachers fixated on their effects. Also, novice teachers did not show the intention to notice classroom events. In short, this study clearly showed that eyetracking technology could make beneficial contributions to teacher education. Concerning this, Van den Bogert et al. (2014) asserted that the eye-tracking method can be used in the dynamic domain of classroom management. Also, they claimed that to investigate the teacher's visual perception and implicit cognitive processes, the eyetracking method can be adapted. Another study reveals that the eye-tracking method can be employed to assess the teaching and classroom management skills of teachers (Wolff et al., 2016). According to Wolff et al. (2016), visual attention was studied in various research disciplines, but there is a lack of studies related to teachers' vision. The authors in this study attempted to explore the differences between experienced and novice teachers regarding classroom events interpretation by using an eyetracking method. In the study, 35 expert secondary teachers, and 32 novice teachers participated. The participants were shown novel videos as stimuli that were taken from the perspective of the teacher in actual lessons. The analysis of eye movements showed that novice teachers had a more disorganized vision, whereas; the expert teachers were concentrated. Also, the expert teachers' vision is larger than the novice ones while watching the videos. Moreover, the expert teachers paid their attention to where relevant information is; on the other hand, the novice ones' attention was messy. As a result, this study demonstrated how eye-tracking methodology could be applied to investigate the relationship between instructors' teaching skill and their visual attention. Furthermore, eye-tracking methodology can be used to explore the gaze behaviors of a teacher in different cultures (McIntyre et al., 2017). McIntyre et al. (2017) employed a wearable eye tracker to study the gaze behaviors of expert and novice teachers in real-world classroom environments in two different cultures: Hong Kong and the UK. In the study, eye movements were analyzed regarding eye movements during talking (communicative gaze) and questioning (attentional gaze), in addition to expertise and cultures. Eye-tracking outcomes displayed that experienced teachers fixated longer on the students and better performed in terms of 
gaze efficiency than novices during communicative and attentional gaze. Concerning cultural differences, the UK teachers performed a greater attentional sufficiency, on the other hand; Hong Kong teachers showed a better performance in the communicative gaze. In this study, the authors implied that the results may be useful for training programs in different cultures. 


\section{CHAPTER 3}

\section{RESEARCH METHODOLOGY}

The main purpose of the study is to explore if it is possible to evaluate and improve the faculty members' classroom management skills by using a wearable eye tracker. Secondly, this study aims at showing how wearable eye tracker can be employed in a real-world classroom environment as a feedback tool for classroom management. Accordingly, this chapter gives information about how the study was conducted.

\subsection{Research Question}

How can a wearable eye tracker be employed in real-world classroom environments as a training and assessment tool to improve faculty members' classroom management skills in higher education?

\subsection{Research Population}

The target population of the study covers faculty members in higher education institutions across the world. However, the accessible population of the study consists of two male faculty members who have been working in a university for more than ten years in Turkey. The reason for selecting experienced faculty members was that they are expected to perform fewer false behaviors about classroom management, compared to inexperienced ones. Therefore, it was thought that three weeks were enough to observe behaviors of two participants in relation to classroom management. If inexperienced faculty members had been selected, three weeks would have been insufficient to change false behaviors related to classroom management. It was foreseen that the study was going to last for more than six weeks because inexperienced faculty members are anticipated to perform more false behaviors about classroom management. The reason for choosing two participants was related to the 
duration of the study. Increasing the number of the participants was going to prolong the duration of data collection.

In the current study, one of the participants has been working at the Department of Educational Sciences and another one has been working at the Department of Physics. This means that one of the participants has educational science background and another participant has no educational science background. More detailed information about the participants' characteristics can be seen in Table 3-1. Generally, there are two common types of classroom styles where faculty members teach courses across the universities: Traditional and Auditorium. Thus, for traditional style, the Department of Educational Sciences was appropriate. Auditorium styles generally exist in the Department of Physics. Consequently, the wearable eye tracker was employed to improve classroom management skills of the faculty members in two popular types of classroom environments throughout the universities. Before collecting data from actual participants, a pilot study was conducted in an auditorium in the summer term. A female faculty member from the Department of Physics voluntarily took part in the pilot study.

In the current study, the purposive sampling method was adopted because according to Crossman (2018), this type of sampling methods makes it easier for the researchers to reach the targeted population quickly. Also, Crossman says that purposive sampling is valid if sampling for proportionality is not the main issue. Furthermore, there are many types of purposive sampling, one of which is "Critical Case Sampling." In this study, Critical Case Sampling was employed as purposive sampling. Concerning Critical Case Sampling, Crossman said that researchers are expected to study one case and create a general understanding that can be applied to other cases. Similarly, Patton (1990) considers: "If it can happen there, it can happen anywhere." Accordingly, the current study can show the applicability of wearable eye trackers to improve classroom management skills of faculty members across the universities. 
Table 3-1: Characteristics of the Participants

\begin{tabular}{ccccc}
\hline$\#$ & Participants & The Department & Experience Level & Gender \\
\hline $\mathbf{1}$ & P01 & Educational Sciences & More than ten years & Male \\
\hline $\mathbf{2}$ & P02 & Physics & More than ten years & Male
\end{tabular}

\subsection{Research Design}

The purpose of the current study is to explore if it is possible to use wearable eyetracking technology in order to improve the faculty members' classroom management skills by recording their visual attention. Also, the current study attempted to demonstrate how a wearable eye tracker can be used in real-world classroom environments to improve classroom management of the faculty members. Therefore, a case study as research design was adopted in the current study. Case studies can be employed for validating a method. In addition, a case study can be appropriate if the purpose of a research is to find answers for "How" type of questions (Teegavarapu \& Summers, 2008). A case study method is useful for those who want to study real-life conditions (Zainal, 2007). In the current study, a case study method was adopted because two faculty members took part in the study. According to Zainal (2007), case studies are an ideal type of methods when the number of the participants is very limited. Furthermore, case studies allow the researchers to collect data from various types of sources (Baxter \& Jack, 2008). In the current study, eye-tracking, video camera, retrospective think aloud, and interview data were employed to find answers for the research question. This means that data were collected by different types of sources.

\subsection{Instrumentations}

There are four types of data that were acquired during data collection process: Eyetracking, Video Camera, Retrospective Think Aloud (RTA), and Interview. To record the eye movements of the participants, a wearable eye tracker (Tobii Pro Glasses 2 $100 \mathrm{~Hz}$ Live View Wireless) was employed in the study (see Figure 3-1). The eye 
tracker consists of two parts: Head Unit and Recording Unit. There is a full HD wideangle scene camera, Gyro, and accelerometer, two cameras for per eye, microphone and nose pad on the head unit (see Figure 3-2). The head unit of Glasses 2 weighs only 45 grams. The recording unit includes a battery and SD card. The data were recorded in the SD card.

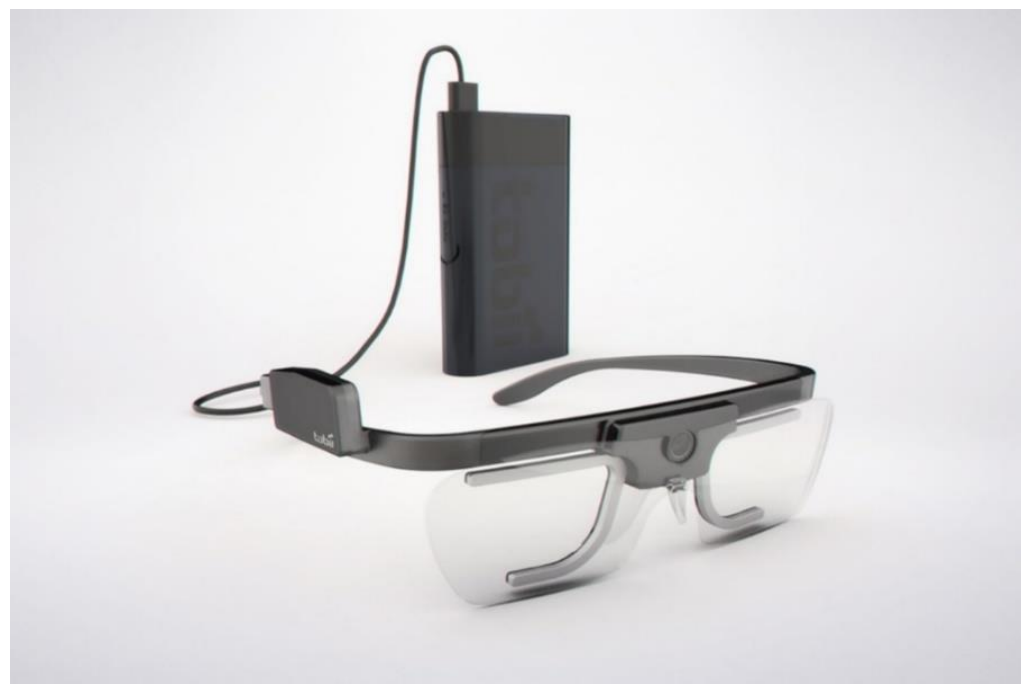

Figure 3-1: Tobii Pro Glasses 2 (A Wearable Eye Tracker, as cited in tobiipro.com)

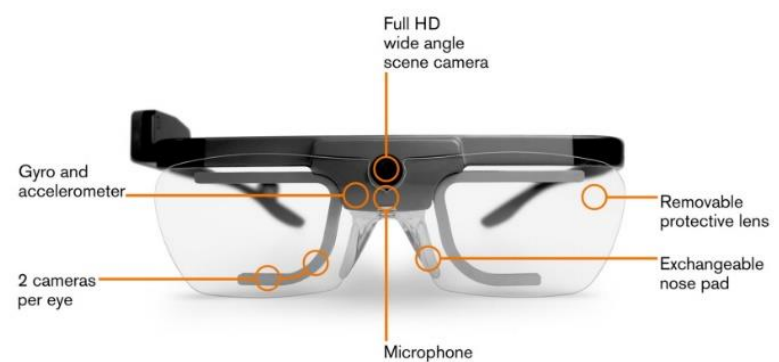

Figure 3-2: Parts of Glasses 2 Head Unit (as cited in tobiipro.com)

Moreover, a video camera was employed to record gestures and facial expressions of the faculty members during the course (see Figure 3-3). Eye movements were analyzed in the software of the eye tracker. The software makes it possible for researchers or professional to calculate statistics of eye movements and generate visualizations of eye movements like gaze plot and heatmap. Moreover, the 
synchronization of the records (eye movements view and camera view) were integrated into a software; thus, with the help of this software, the faculty members can concurrently watch their eye movements and gestures in the RTA sessions. Furthermore, in the Retrospective Think Aloud Sessions (RTA), the participants' comments on their classroom management performance were recorded to support visual behaviors of them. Also, the purpose of the RTA sessions was to enable the participants to explore their own misbehaviors about classroom management. Besides, a short interview session was conducted only once with the participants at the end of the third week. Interview questions can be found in the part of Appendices (see Appendix A).

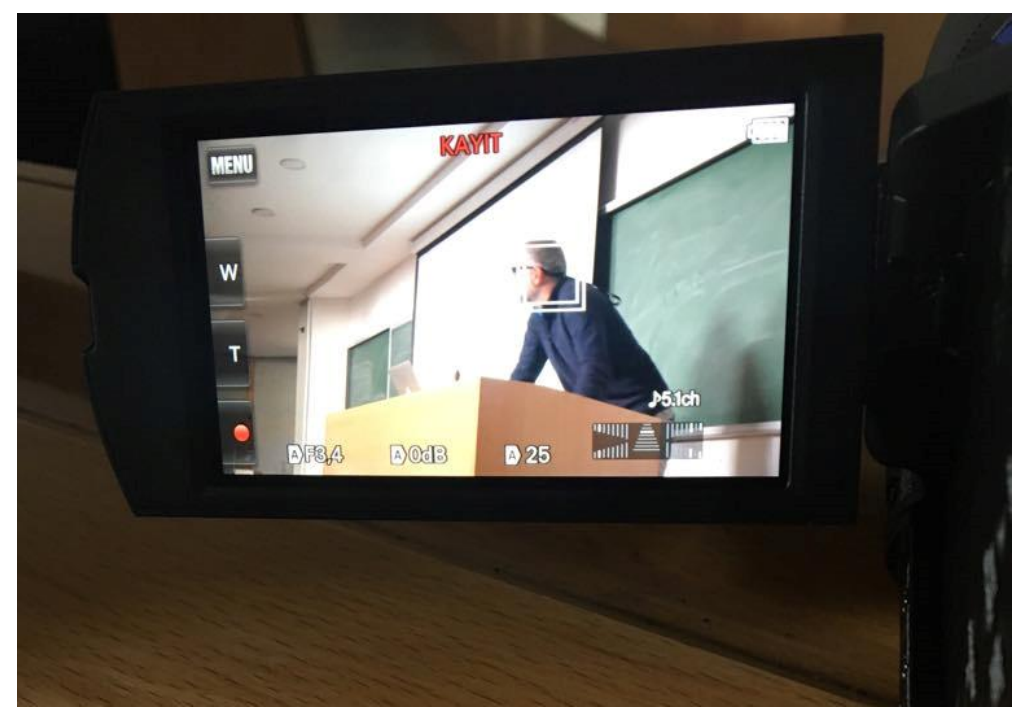

Figure 3-3: A View Showing Video Camera Recording

\subsection{Study Settings}

In the current study, the data were collected in two types of classroom environments: Traditional Classroom and Auditorium (see Table 3-2). In traditional classroom environment, the faculty member from the Department of Educational Sciences gave the course of "Introduction to Education". In this course, he generally explained the concepts about education. On the other hand, the faculty member from the Department 
of Physics gave the course of "General Physic". He adopted lecture method while teaching the course. This method is known as teacher-centered approach.

Table 3-2: Types of Classroom Environment

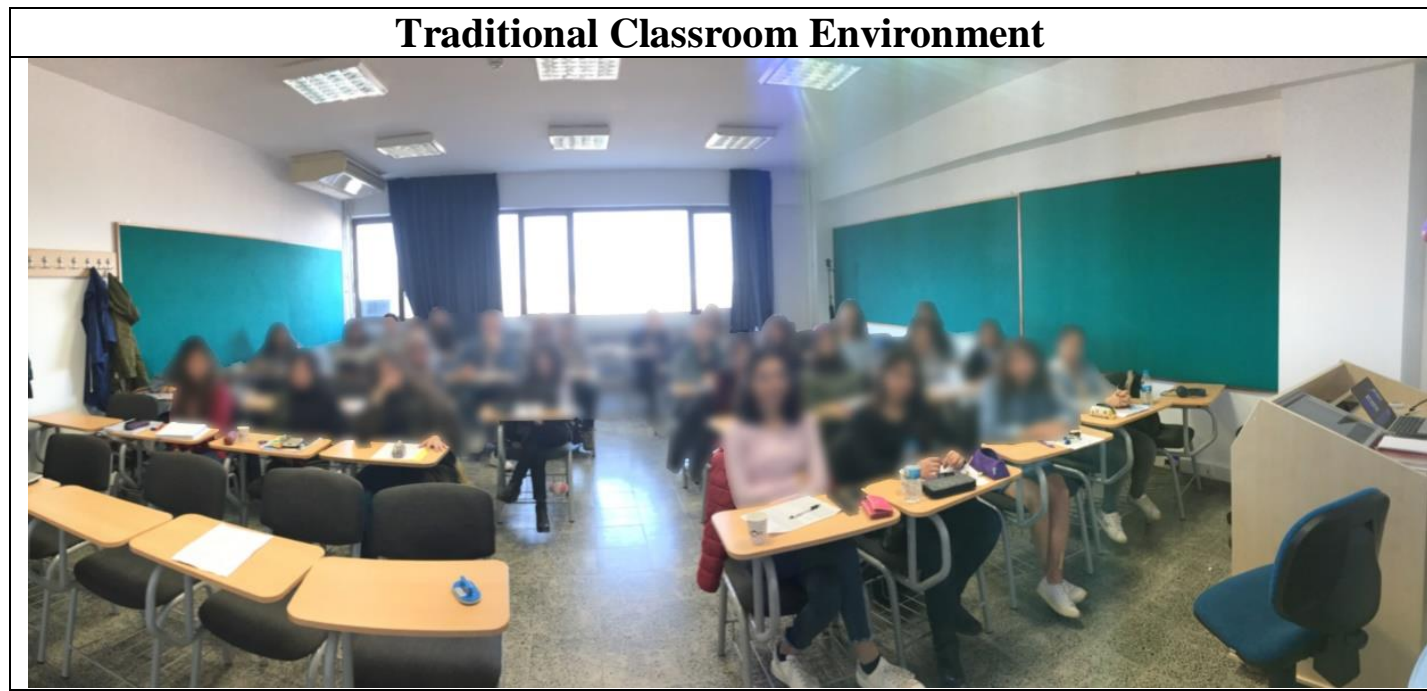

\section{Auditorium Classroom Environment}

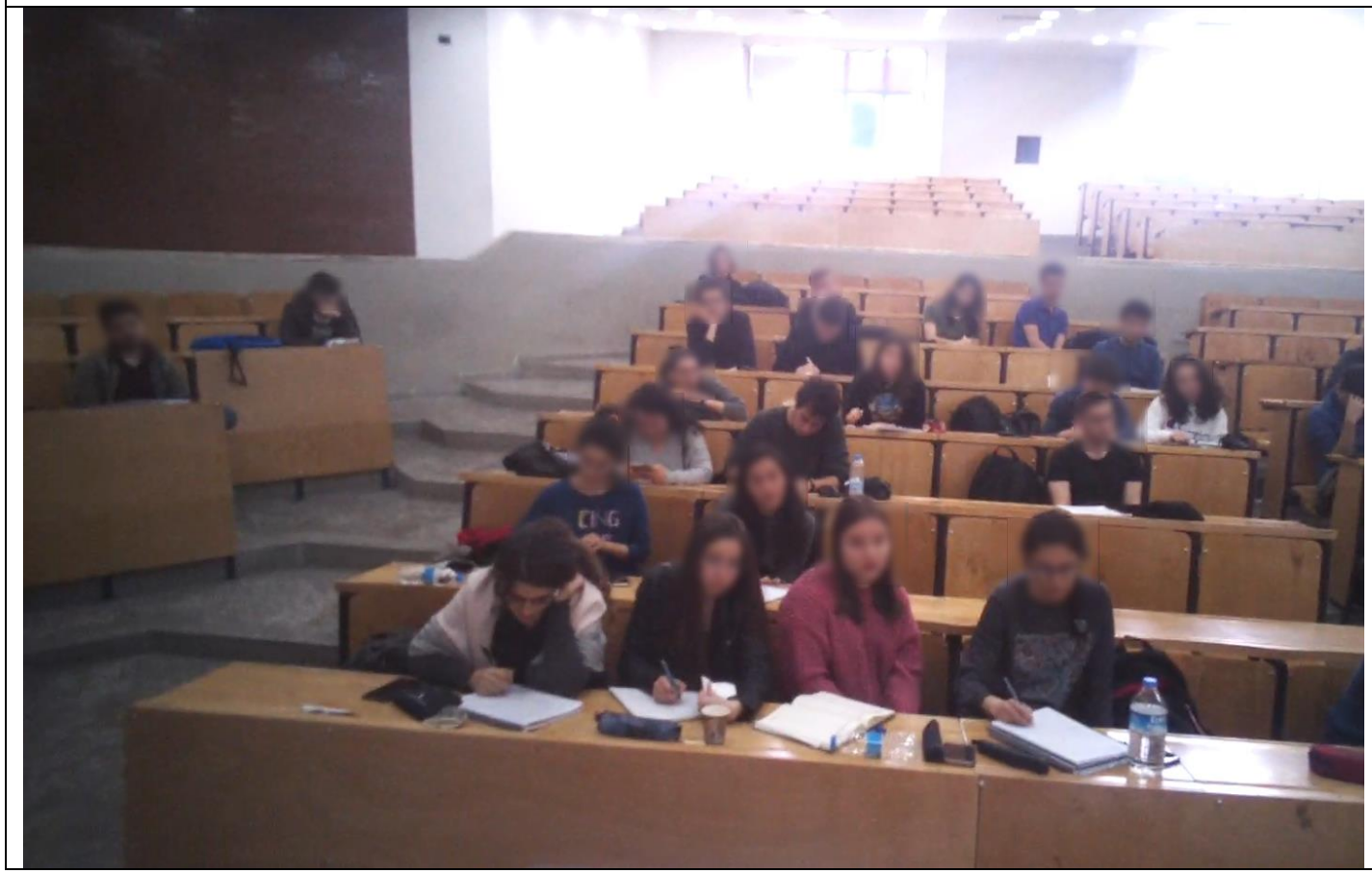




\subsection{Data Collection}

In the summer term, a pilot study was conducted with an experienced female faculty member. In the pilot study, the data were gathered in only a 45-minute course and in a type of auditorium classrooms at the Department of Physics. In this way, we had the chance to see the probable problems we might encounter during the actual study. Later, two experienced faculty members took part in the current study. They wore a wearable eye tracker to track and record their visual behaviors while lecturing. In addition, while they were lecturing, a video camera was used to record the participants' gestures and facial expressions. The video camera was placed in the back of the class, so the faces of the students were not recorded. The first group of data including eye-tracking, video camera, RTA, and interview were collected in a traditional classroom at the Department of Educational Sciences. The second group of data were gathered in an auditorium at the Department of Physics. The more details about the courses in which the data were recorded can be found in Table 3-3.

\section{Table 3-3: Details About the Courses}

\begin{tabular}{clll}
\hline The Participant & The Lesson & The Students & The Classroom Type \\
\hline P01 & Introduction to & $1^{\text {st }}$ year & Traditional \\
(faculty member) & Education & university students & Classroom \\
\hline P02 & Physic (General & $1^{\text {st }}$-year university & Auditorium \\
(faculty member) & Physic II) & student & \\
\hline
\end{tabular}

The faculty members and the students were informed about the study and how eye trackers work before collecting the data at the beginning of the courses. The data were gathered from the faculty members and at the same course three times. During collecting the data, the classroom environments never changed. Table 3-4 gives information about the dates of data acquisition and duration of courses (minute). 
Table 3-4: Dates of Data Collection

\begin{tabular}{cccc}
\hline Participant & \# of weeks & Date & Course Duration \\
P01 & 1 st Week & October 20, 2018 & 49 minutes \\
P01 & $2^{\text {nd }}$ Week & December 4, 2018 & 44 minutes \\
P01 & $3^{\text {rd }}$ Week & December 11, 2018 & 46 minutes \\
P02 & $1^{\text {st }}$ Week & February 25, 2019 & 48 minutes \\
P02 & $2^{\text {nd }}$ Week & March 25, 2019 & 30 minutes \\
P02 & $3^{\text {rd }}$ Week & April 4, 2019 & 48 minutes
\end{tabular}

After collecting the data from each course, eye-tracking and video camera data were synchronized in a software. Figure 3-4 shows interface of the software. By this software, the faculty members could observe their eye movements and gestures in a synchronized way in the RTA sessions.

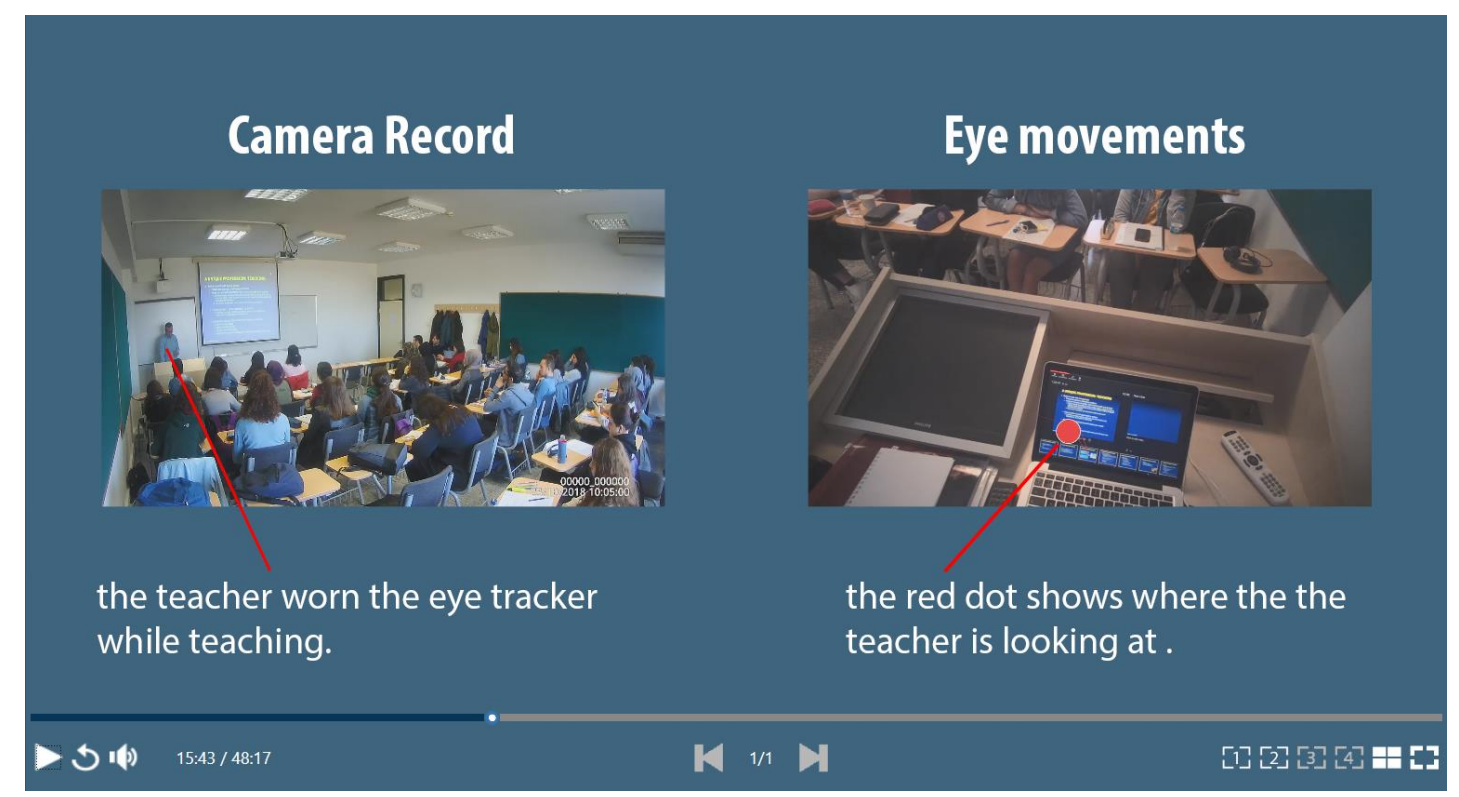

Figure 3-4: A Screenshot of Software

Moreover, eye movements were analyzed by a software of the wearable eye tracker. Then, the analysis results of eye movements and the synchronized data (the video records and eye movements) were presented to the faculty members. In the RTA sessions, they were expected to explore their misbehaviors about classroom management. In addition, in the RTA sessions, they were requested to interpret the 
results and the synchronized data. While they were interpreting the data, they were asked to think aloud. Their comments were recorded to support eye-tracking data. When the need raised, they received feedback about classroom management. This process was applied for three weeks and it was the same for both of the courses. Besides, at the end of the $3^{\text {rd }}$ week, all results were presented to the participants. Next, a short interview session was conducted with the participants at the end of the $3^{\text {rd }}$ week to learn their ideas about the use of eye-tracking technology in improving classroom management. Figure 3-5 clearly summarizes the process of how to collect the data during the three weeks for two lessons. Data collection process lasted for approximately two months for two different courses. 

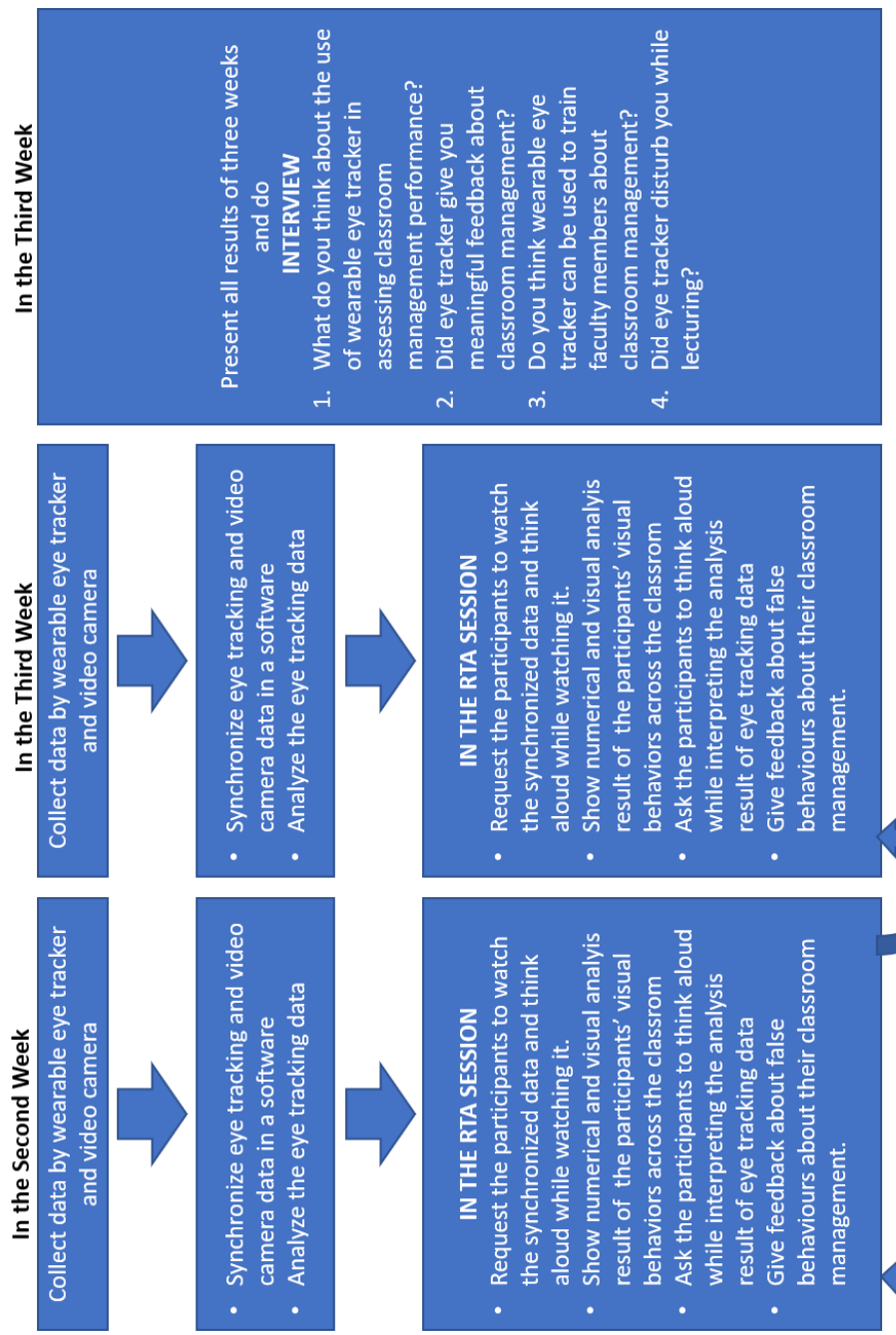

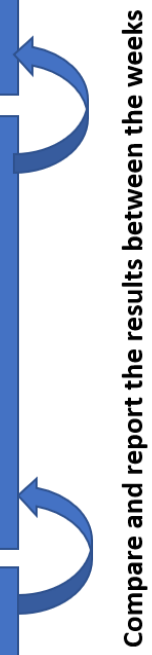
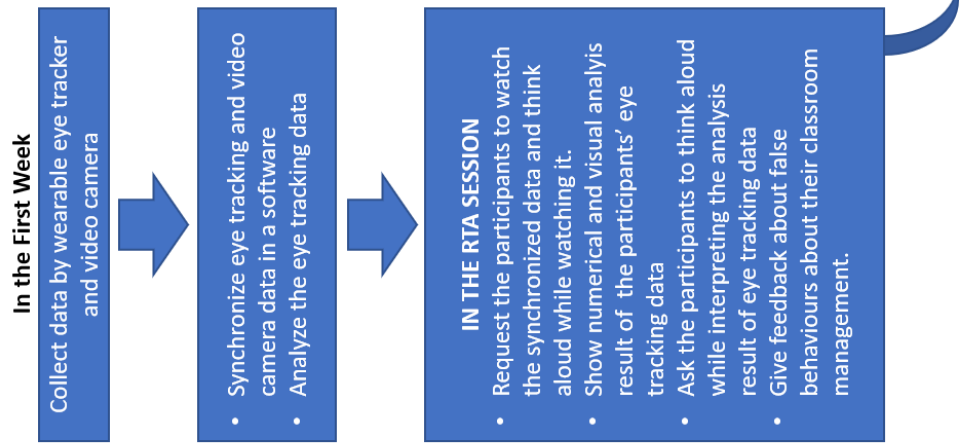

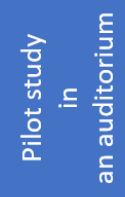

Figure 3-5: Procedure of Data Collection 


\subsection{Data Analysis}

Triangulation method was adopted in this study to answer the research question. Triangulation means the use of numerous methods to collect data in a research study. It is employed to improve the reliability of a research study. Using several types of data minimizes the biases that can be found in one method (Hastings, 2010). According to Hastings (2010), there are four types of triangulation. In the current study, methodological triangulation was employed. It is the most commonly used one among triangulation forms. This form merges several sources of methods to investigate a problem. As this method compares several types of data, it increases the consistency among the information that are gathered by different methods (Hastings, 2010).

In the current study, the qualitative data were gathered by heatmap and gaze plot map of eye movements. Also, Retrospective Think Aloud (RTA) and Interview sessions were employed within the qualitative data. The quantitative data was collected by the metric, Total Visit Duration on AOIs. The metric, Total Visit Duration, gave us information about how much time the faculty members spent on AOIs. Eye-tracking and RTA data were collected for three weeks. Interview data were acquired only once at the end of the $3^{\text {rd }}$ week to explore the ideas of the participants about the use of wearable eye tracker in real-world classroom environments. In addition, video camera recordings were gathered in the $1^{\text {st }}$ and $2^{\text {nd }}$ weeks to support eye-tracking results (see Table 3-5). Eye movement data were analyzed in the software of the eye tracker, which presented both qualitative and quantitative data. Automatic mapping was firstly preferred to code eye movements on classroom environments. Then, manual mapping was used to correct the wrong and missing codes. After mapping processes, the software automatically presented qualitative data of eye movements (heatmaps and gaze plot map) on the classroom environments. For quantitative data, the classroom environments were firstly divided into the parts (known as AOIs) such as the students, the board \& slides, and the computer. Figure 3-6 shows the AOIs of traditional classroom environment. The same process was also applied for Auditorium classroom 
environment; it was divided into the parts including the students, the board \& slides, and the computer. In addition, The AOI on the students was divided into two main parts as Front and Back, which made it possible for us to calculate the distribution of the participants' visual attention across the students sitting at back and front rows. Total Visit Duration as metric was selected to measure how much time the teachers spent on AOIs.

Table 3-5: Data Types of the Study

\begin{tabular}{|c|c|c|c|c|}
\hline Weeks & Eye movement & $\begin{array}{c}\text { Retrospective Think } \\
\text { Aloud }\end{array}$ & $\begin{array}{c}\text { Video } \\
\text { Camera }\end{array}$ & Interview \\
\hline $1^{\text {st }}$ week & & & & \\
\hline $2^{\text {nd }}$ week & & & & \\
\hline $3^{\text {rd }}$ week & & & & \\
\hline
\end{tabular}
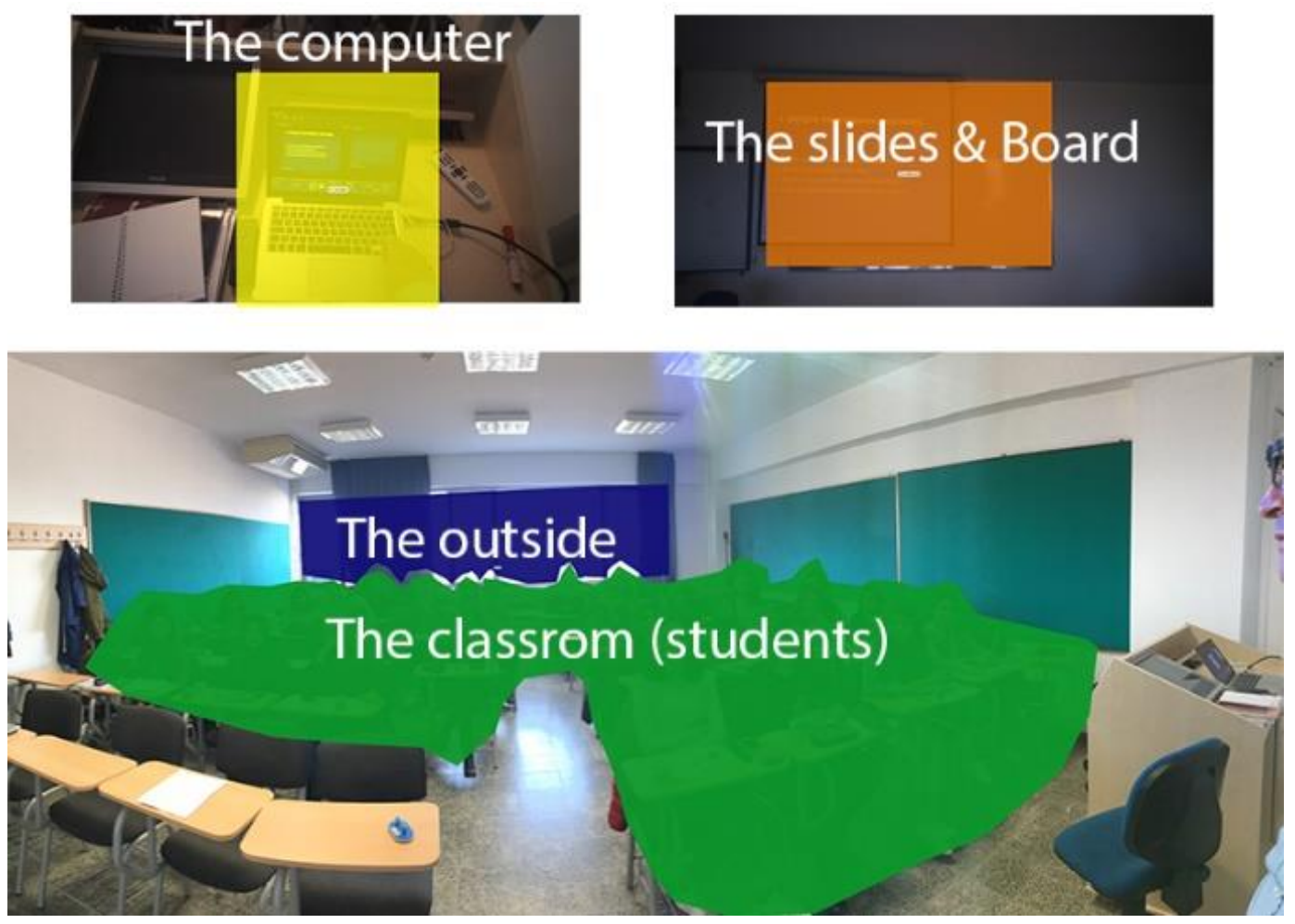

Figure 3-6: AOIs of the Traditional Classroom Environment 


\subsection{Validity and Reliability}

Before collecting the actual data from the participants, a pilot study was conducted in the summer term to check appropriateness of wearable eye trackers in a real-world classroom environment. The result of the pilot study showed that wearable eye tracker was accomplished at capturing eye movements of the faculty members. Besides, this study made it possible for us to foresee potential problems that will occur in the course of gathering actual data. To validate eye-tracking results, a master student who is experienced in eye-tracking methodology reviewed them and the interpretations were compared with each other. Besides, in the RTA sessions, the participants' thoughts and comments on their eye-tracking results were recorded. Eye movement analysis results were supported by them in the RTA sessions. Hereby, it was aimed to check the consistency between the findings of the eye movements and the participants' thoughts. Moreover, open-ended interview questions were prepared in accordance with the instructions of the supervisor. They were asked to both of the participants. 



\section{CHAPTER 4}

\section{FINDINGS AND ANALYSIS}

\subsection{Introduction}

This chapter will present the analysis results of eye-tracking data that were recorded by the wearable eye tracker. It will also demonstrate the interview results of the participants. Moreover, this section includes comments the participants made while they were interpreting analysis results of eye movements and records (eye-tracking and video camera data).

Firstly, the eye movements were analyzed by the software of the eye tracker. As explained in chapter 3 , the software of the eye tracker is capable of analyzing gaze behaviors and giving numerical values about gaze behaviors such as total visit duration (second). Accordingly, in this section, visual analysis of eye movements such as gaze plot and heat map will be presented. Moreover, the visual analysis will be supported by numeric values by using the metric, total visit duration.

\subsection{Gaze Analysis Results of the $1^{\text {st }}$ Participant}

Eye movements of the $1^{\text {st }}$ participant were recorded by the wearable eye tracker and they were analyzed by the previously mentioned software. The data were collected in a traditional classroom environment in the course of "Introduction to Education" at

the Department of Educational Sciences. The classroom environment the faculty member interacted with was divided into four areas including the computer, slides \& board, the outside and the students (classroom) (see Figure 4-1). In this way, how much time the participant spent on these divided areas was calculated. In eye-tracking research, the divided areas are also known as the Areas of Interests (AOIs). Total visit duration (a metric) was used to calculate the time the participant spent on AOIs. 

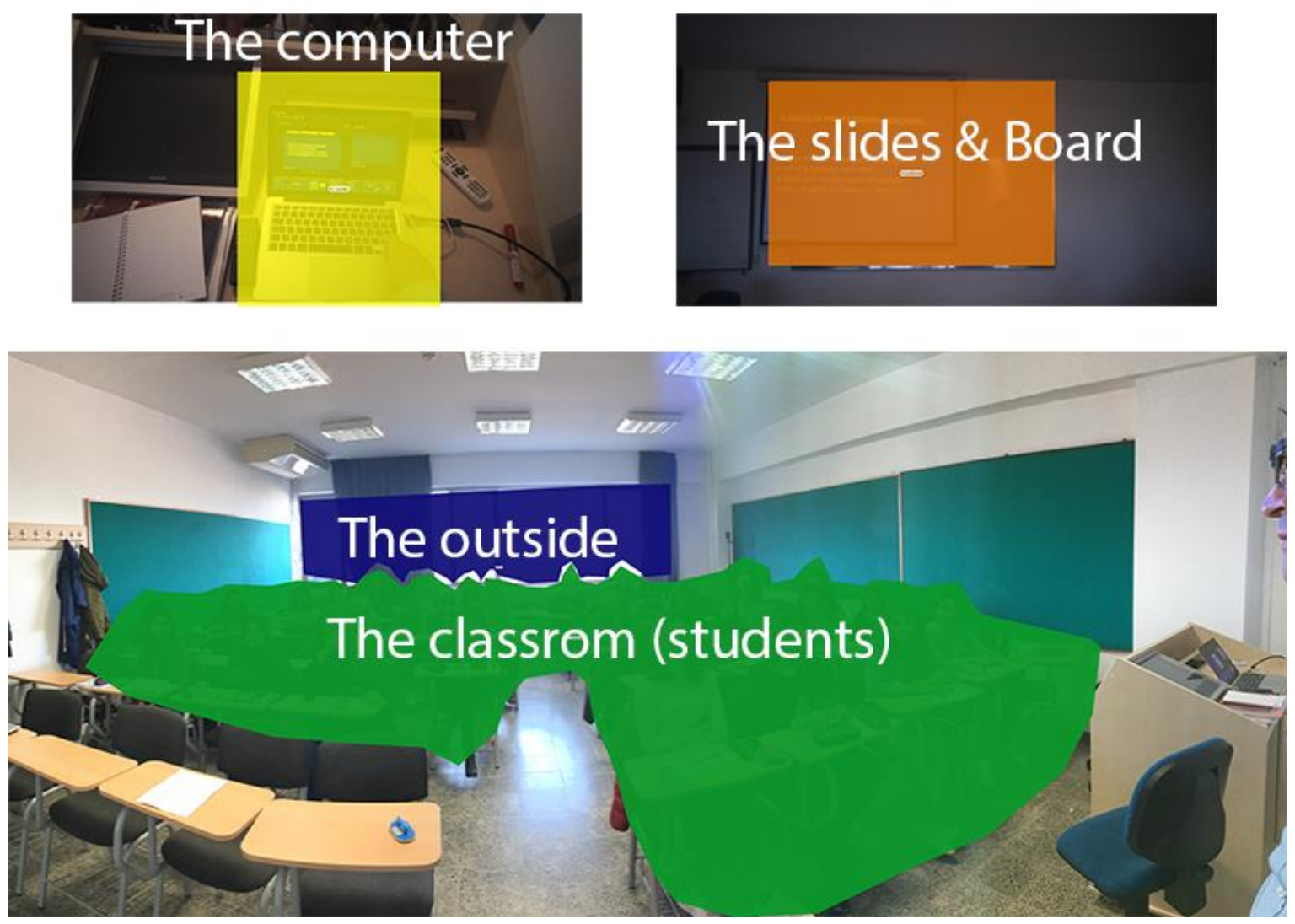

Figure 4-1: Areas of Interests (AOIs)

\subsubsection{The First Week}

Expectedly, eye-tracking data that was acquired in the $1^{\text {st }}$ week showed that the participant spent most of the time making eye contact with the students (see Figure 4-2 \& Figure 4-3). That is, during a nearly 50-minutes course, the faculty member spent approximately 41 minutes making eye contact with the students. Moreover, he spent nearly two minutes on the slides, board, and computer. However, the time he spent looking at the outside was a little bit high, around 2,5 minutes. Regarding this matter, "I am aware of that I fixated a little bit much on the outside", the faculty member said in the RTA session. In the following, he mentioned that the windows' design and disturbing light environment of the classroom was the reason for this issue. By exploring this behavior in the RTA session, it was expected from the faculty to decrease the time spent looking at the outside in the $2^{\text {nd }}$ and $3^{\text {rd }}$ week. 


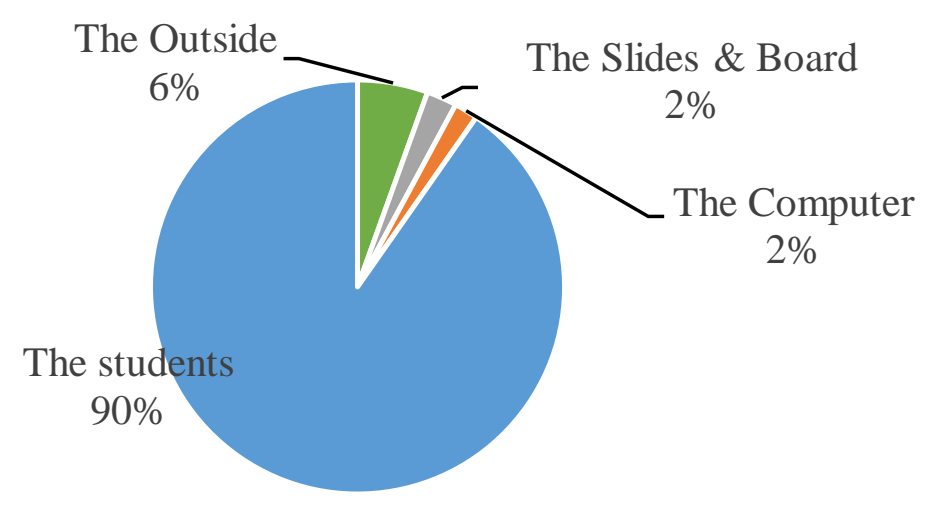

Figure 4-2: Percentage of Total Time Spent on the AOIs

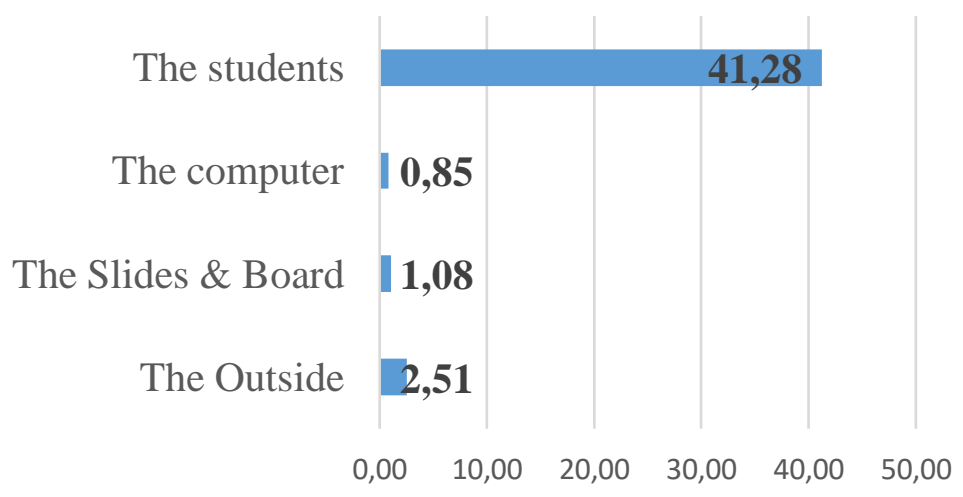

Figure 4-3: Total Time Spent on the AOIs (min)

Furthermore, the faculty member's visual attention across the students sitting at the front and back rows of the classroom was investigated. He spent $70 \%$ of the course time by making eye contact with the students sitting at the back of the classroom. In contrast, the time spent on the front rows of the classroom was 30\% (see Figure 4-4). The heatmap of his visual attention support this statement; he made eye contact with the front rows of the classroom less, compared to the back of the classroom (see Figure 4-5 \& Figure 4-6). In the RTA session, the faculty member was asked to comment about these visual behaviors. He said that since high performer students sat in the front rows and others who were likely to perform misbehaviors sat towards the back rows, he spent less time making eye contact with the front of the classroom, compared to the back of it. Besides, the course durations were divided into three parts: The $1^{\text {st }}$ part, 
The $2^{\text {nd }}$ Part and The $3^{\text {rd }}$ Part. The participant's visual behaviors were analyzed over each time. The analysis results showed that the participant spent most of the time fixating on the back of the classroom in the three parts. However, in the $1^{\text {st }}$ part of the course, the participant attempted to make eye contact with the student more evenly, compared to the $2^{\text {nd }}$ and $3^{\text {rd }}$ part of the course.

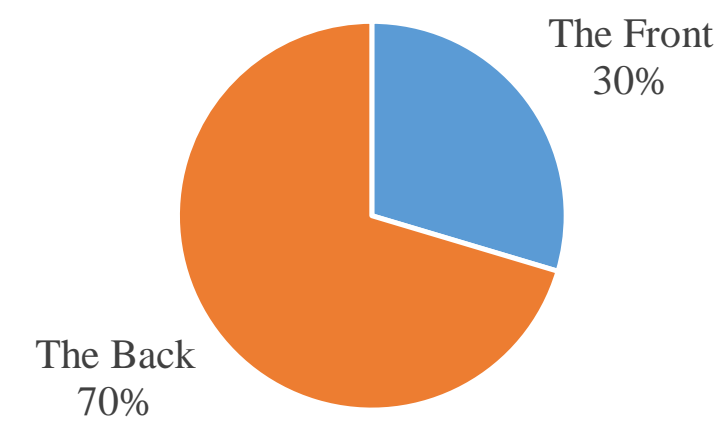

Figure 4-4: \% of Total Time Spent on the Front and Back

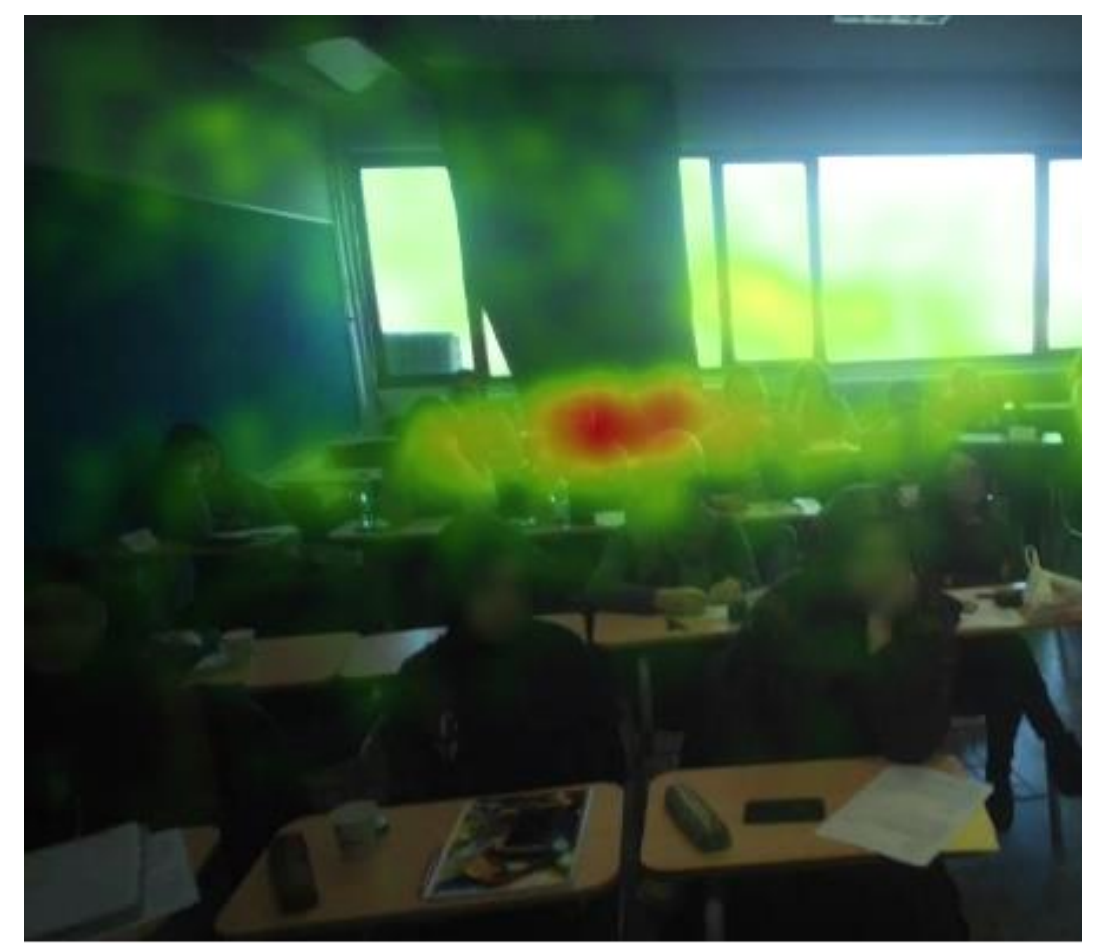

Figure 4-5: Heatmap of the 1st Participant's Visual Attention (Left Area) 


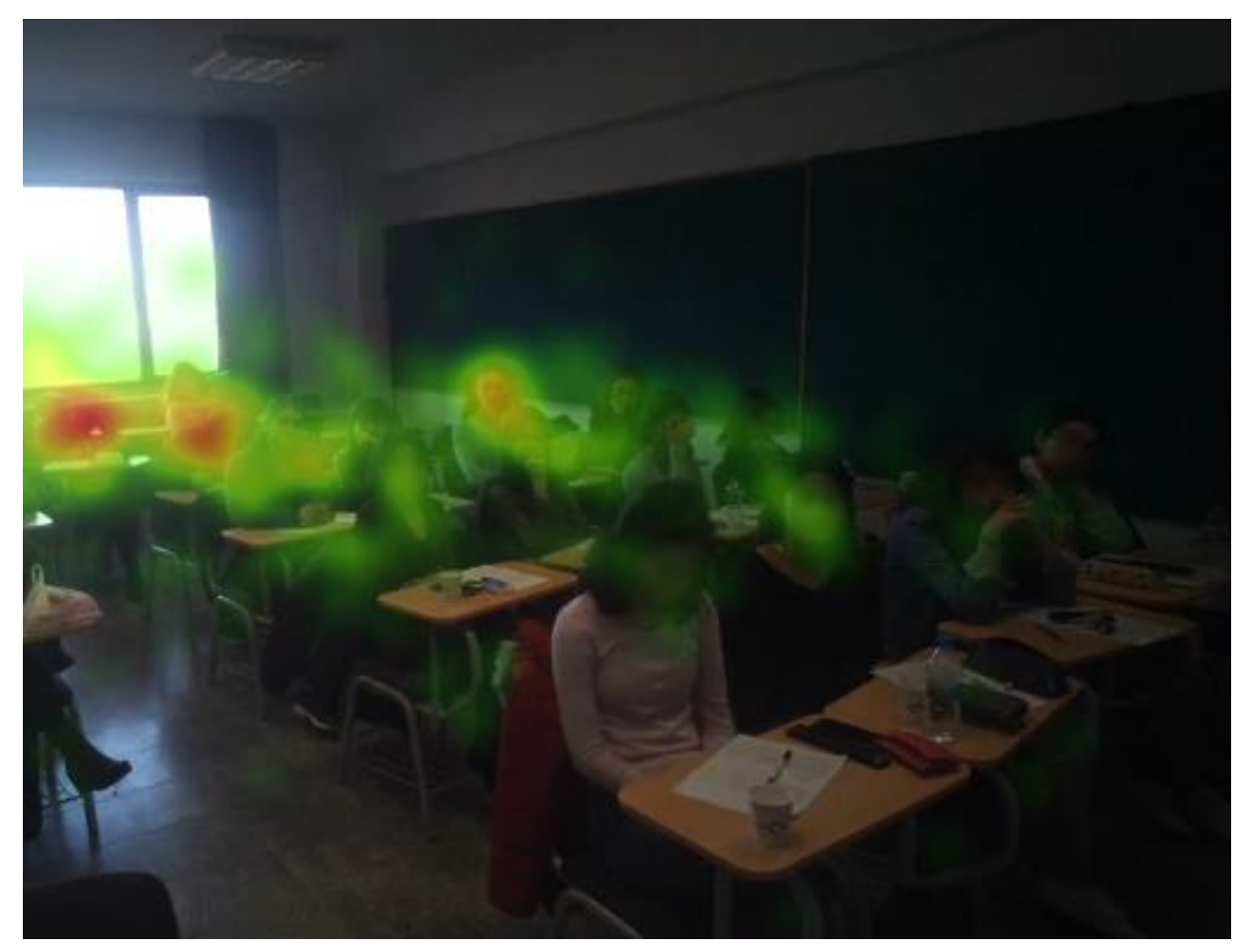

Figure 4-6: Heatmap of the 1st Participant's Visual Attention (Right Area)

\subsubsection{The Second Week}

In the $2^{\text {nd }}$ week, the faculty member was expected to significantly decrease looking at the outside of the classroom after the $1^{\text {st }}$ week RTA session. However, the time spent on the outside is almost as equal as the first-week result (2,51); the teacher spent 2,37 minutes looking at the outside of the classroom. Expectedly, in the $2^{\text {nd }}$ week, he spent most of the lesson time making eye contact with the students, which is the typical gaze behavior the expert teachers perform (see Figure 4-7). Like in the first week, he spent more time on the back rows than the front rows of the class. While the participant spent $41 \%$ of the course time on the front rows, the time spent on the back of the class consists of $59 \%$ of the course time (see Figure 4-8). However, compared to the $1^{\text {st }}$ week, the spent time on the front and the back of the class converged on each other. That is, the time spent on the front of the class increased from $\% 30$ to $41 \%$, whereas that on the back of the class reduced from $70 \%$ to 59 (see Figure 4-4 \& Figure 4-8). 
As a result, after the $1^{\text {st }}$ week RTA session, that can be interpreted that the participant attempted to make more eye contact with the front rows in the $2^{\text {nd }}$ week.

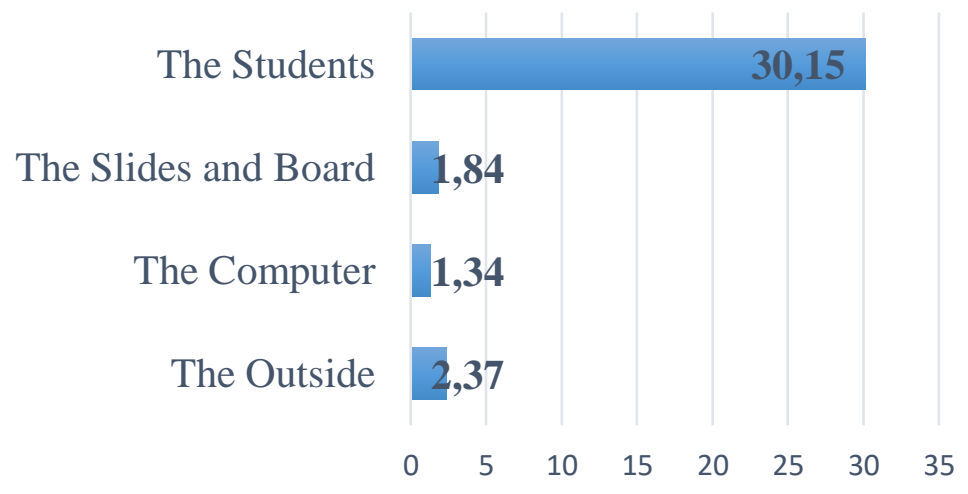

Figure 4-7: Total Time Spent on AOIs (min)

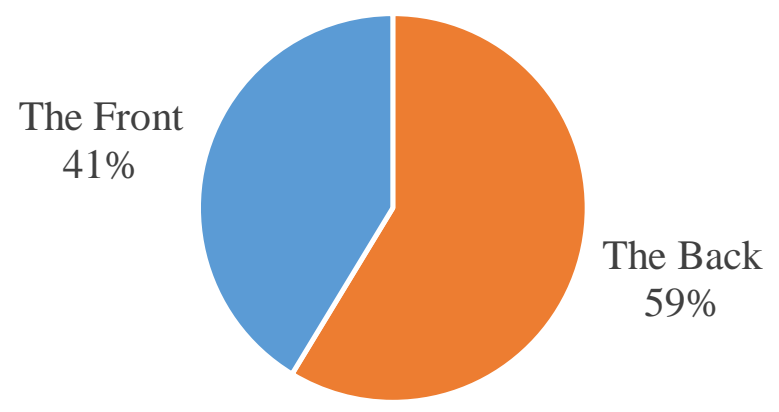

Figure 4-8: \% of Total Time Spent on the Front and Back

Furthermore, according to the course time divisions, the time spent on the front of the class $(55 \%)$ was higher than the back of the class (45\%) in the first 15 minutes of the course. Unlike the first part, in the second and third part of the course time, the participant spent more time on the back than the front. In the RTA session, according to this situation, he explained that the students sitting at the back could get disconnected easily from the topic after the first 15 minutes of the lesson, so he had to make more eye contact with the back rows. His visual behaviors supported this claim; the duration of the gaze showed an increase during the course time. In the first part, the percentage of the time spent on back rows was $45 \%$, and in the second part, it 
increased to $52 \%$. In the final part of the course, the duration of eye contact with the back rows dramatically raised, being $78 \%$.

\subsubsection{The Third Week}

Like in the first and second week, the results of the third week showed that the participant's visual interaction with the students was considerably higher than the other parts of the classroom environment (the computer, slides \& board, and the outside). He spent 40 minutes making eye contact with the students (see Figure 4-9). This time (the $3^{\text {rd }}$ week), the time he spent on the outside, however, decreased to 1.4 minutes. In the first and second week, the time spent on the outside is 2.51 and 2.37 minutes respectively. This can be interpreted that the participant reduced the time spent on the outside after the $2^{\text {nd }}$ week RTA session. However, while getting the record of eye-tracking in the $3^{\text {rd }}$ week, the classroom's window had been closed with the curtain. Thus, the participant considered that it may be a result of the curtain, not eye tracker. Regardless, the eye tracker got him to notice that he spent a considerable time on the outside. Differently from the first and second weeks, he made more eye contact with the front of the class; the total time spent on the back rows is $36 \%$, whereas; that on the front is $64 \%$. Concerning this situation, he commented that as the students who were engaging with their smart phones sat in the front rows, he was in the need of looking at the front rows. In the $3^{\text {rd }}$ week, the heatmap shows that he did not distribute eye movements evenly during lecturing (see Figure 4-10). Analysis of gaze behaviors was done by taking three parts of the course time once again. The results are the same with the general view; the participant spent the most of time on making eye contact with the front rows. Moreover, the participant's visual attention on the students sitting at back and front rows did not change in the three parts of the course. 


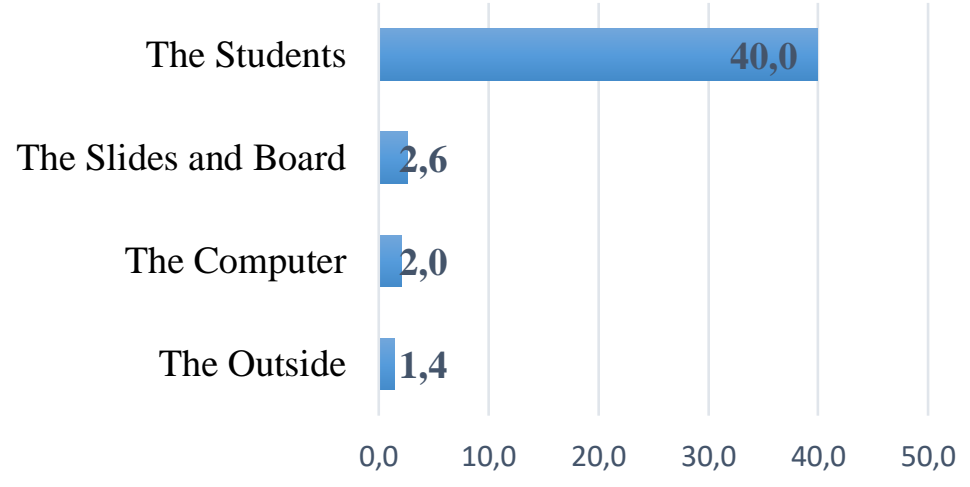

Figure 4-9: Total Time Spent on AOIs (min)

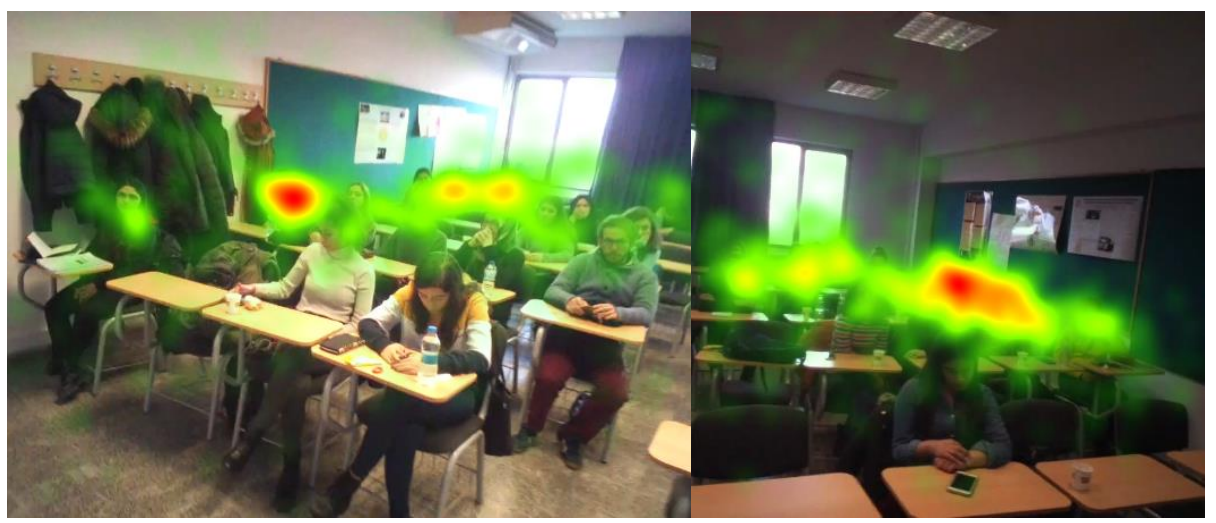

Figure 4-10: Heatmap of the 1st Participant's Visual Attention

\subsubsection{Interview with the $1^{\text {st }}$ Participant}

In the third week, a short interview session was made with the participant. The participant addressed some questions. Firstly, the participant considers that the use of the wearable eye tracker in classroom environment can be useful. He thinks that eye tracker can be employed as a feedback tool to assess classroom management. He commented that wearable eye tracker gives informative feedback about eye contact which is one of the important strategies to control classroom and communicate with students. Besides, he claimed that the wearable eye tracker can be a tool to develop instructional technology. According to him, it can give information about how faculty members interact with technological materials in classroom environment. The participant also mentioned that eye-tracking technology can be more useful for those 
in the universities who haven't gotten pedagogic training. According to him, eyetracking can share meaningful feedback for those who are not equipped with information about classroom management. Finally, the teacher mentioned that the wearable eye tracker discomforted the teacher a little bit in the courses.

\subsection{Gaze Analysis Results of the $2^{\text {nd }}$ Participant}

As is the case with the $1^{\text {st }}$ participant, the same process was implemented for the $2^{\text {nd }}$ participant; eye movements of the participant were recorded by a wearable eye tracker and then they were analyzed. The records were acquired in an auditorium classroom environment in the course of "Physics 106" (General Physic) at the Department of Physics. The auditorium classroom environment was divided into six areas: Left Front, Middle Front, Right Front, Left Back, Middle Back and Right Back) (see Figure 4-11). In addition to this, another Area of Interests (AOIs) the teacher interacted with were the computer and board.

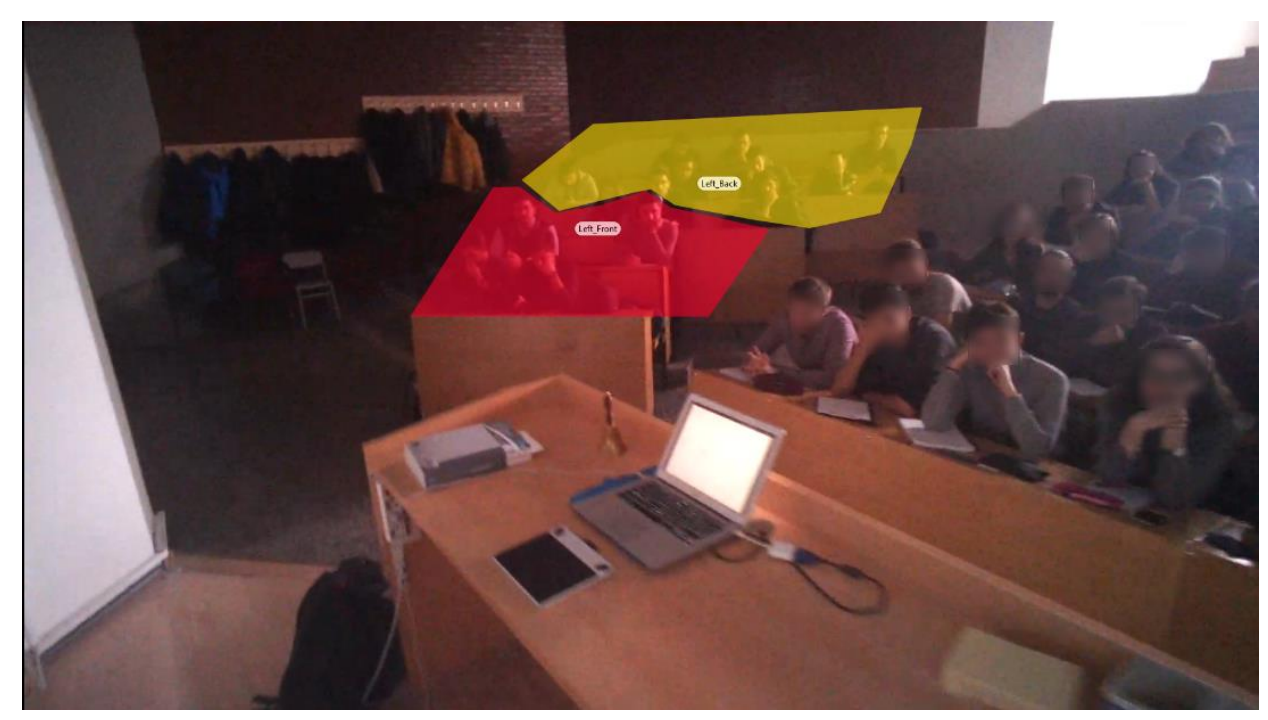




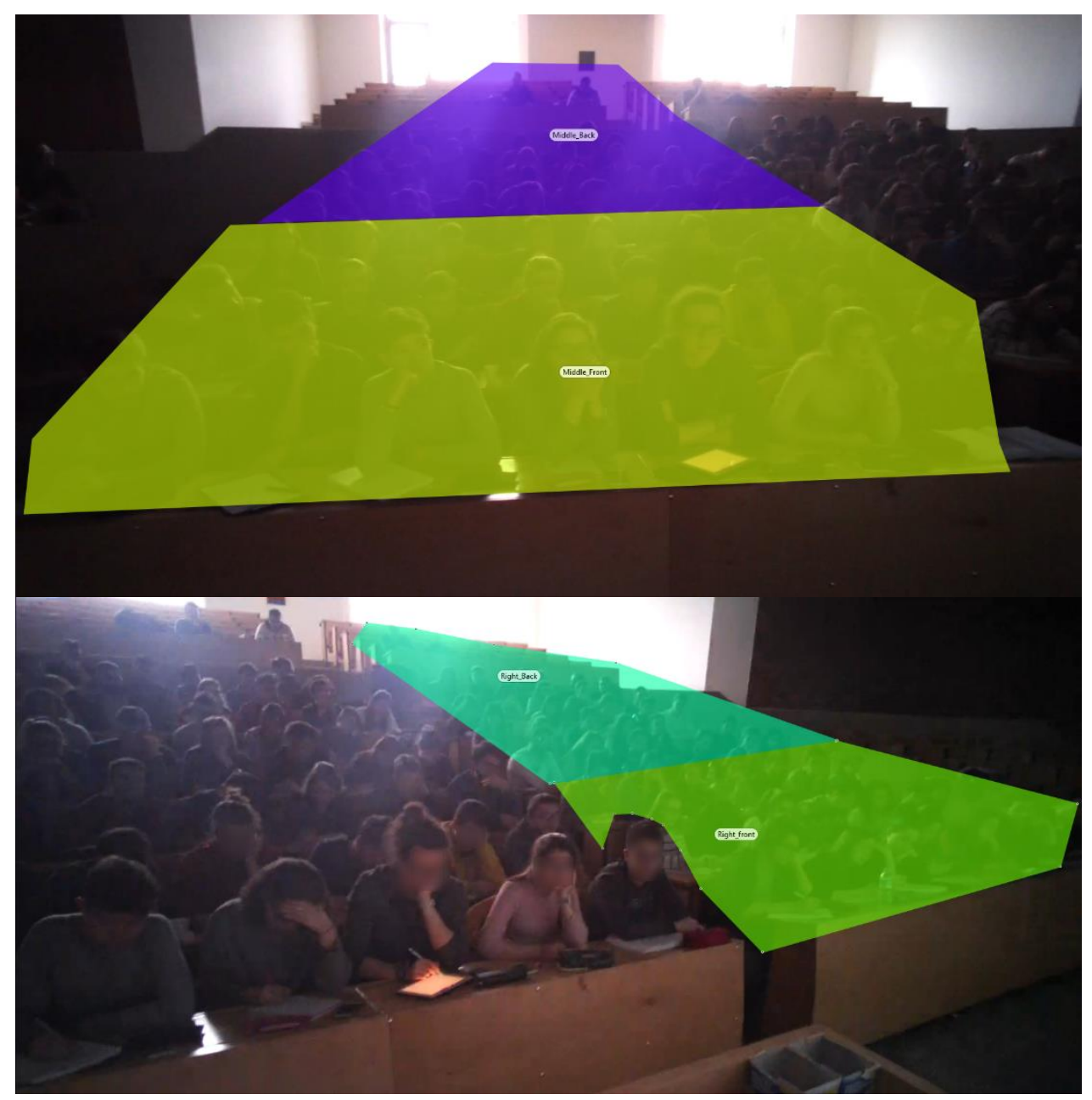

Figure 4-11: AOIs of the Auditorium

\subsubsection{The First Week}

The first-week indicated that the participant spent more time on the students than the computer and the board (see Figure 4-12 \& Figure 4-13). This is an expected result from an experienced teacher. However, he spent 16 minutes looking at the computer and this time is too much. The reason why he spent too much time on the computer is that he was using the smart board system while lecturing. Instead of writing on the board, he preferred writing on the computer while lecturing. 


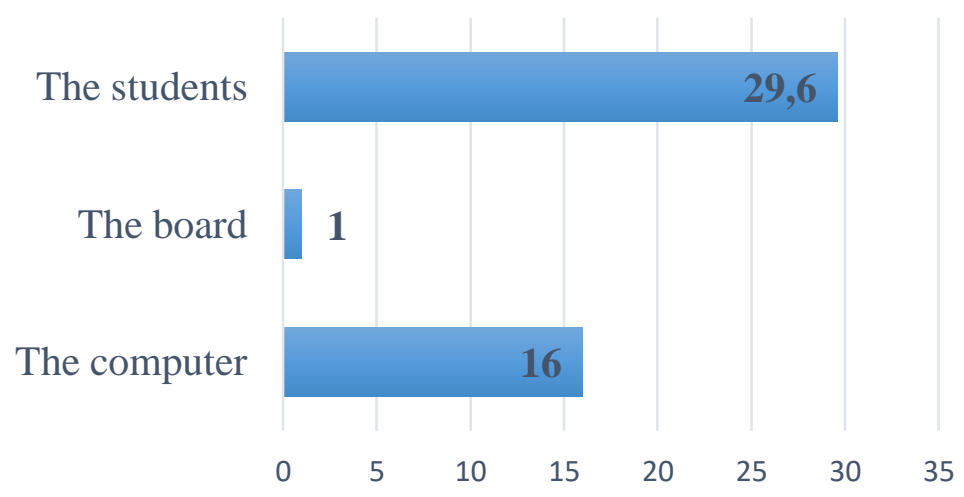

Figure 4-12: Total Time Spent on AOIs (min)

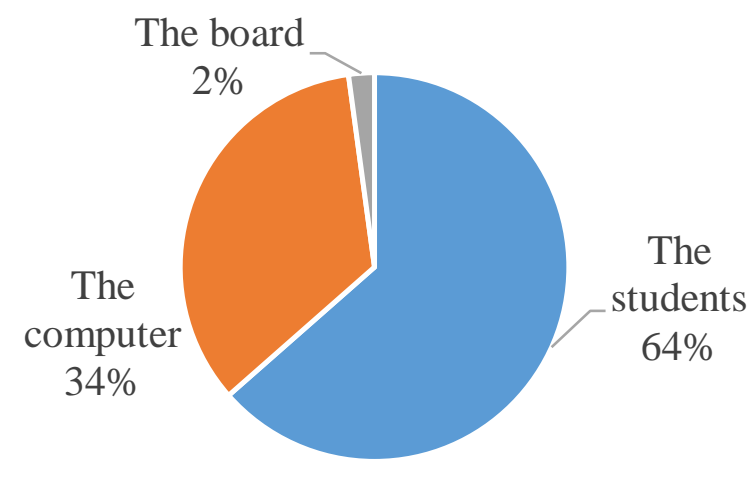

Figure 4-13: \% of Total Time Spent on AOIs

Having looked at the interaction of the teacher with the front and back rows of the classroom, it is seen that he spent most of the time on the front rows. The percentage of the total time spent on the front rows is $95 \%$, while this ratio on the back rows is 5\% (see Figure 4-14). It can be interpreted that the faculty member lectured to only students sitting at the front rows. In the RTA session, he said that "I was aware of that I made more eye contact with the front rows, compared to the back rows, but the result is surprising for me as well because the time spent on the front rows is too much." Heat map of his visual attention displayed that the faculty member didn't distribute his gazes evenly and spent more time on the students sitting at the front rows (see Figure 4-15). 


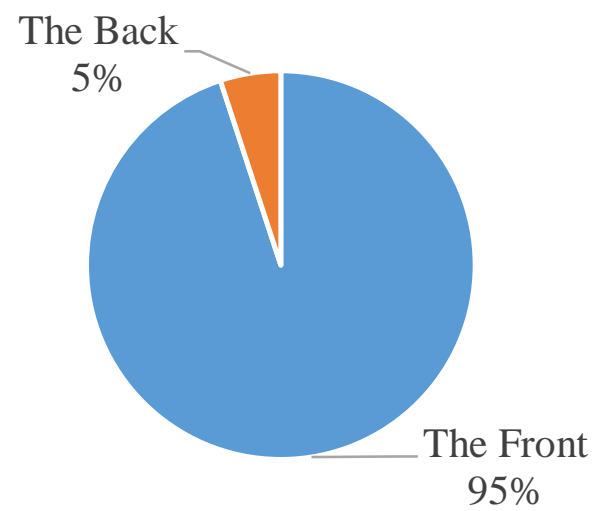

Figure 4-14: \% of Total Time Spent on the AOIs (front and back)

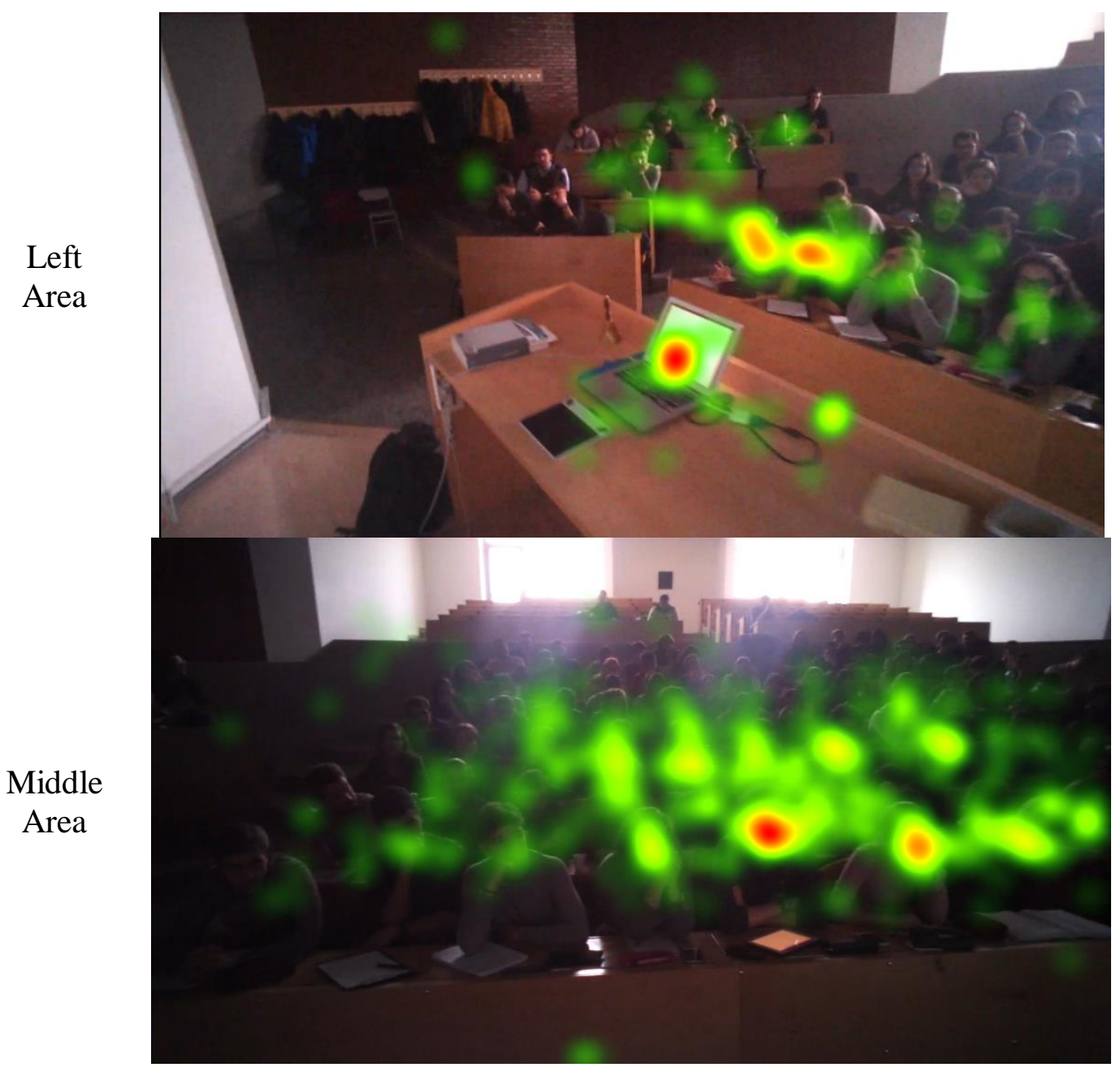




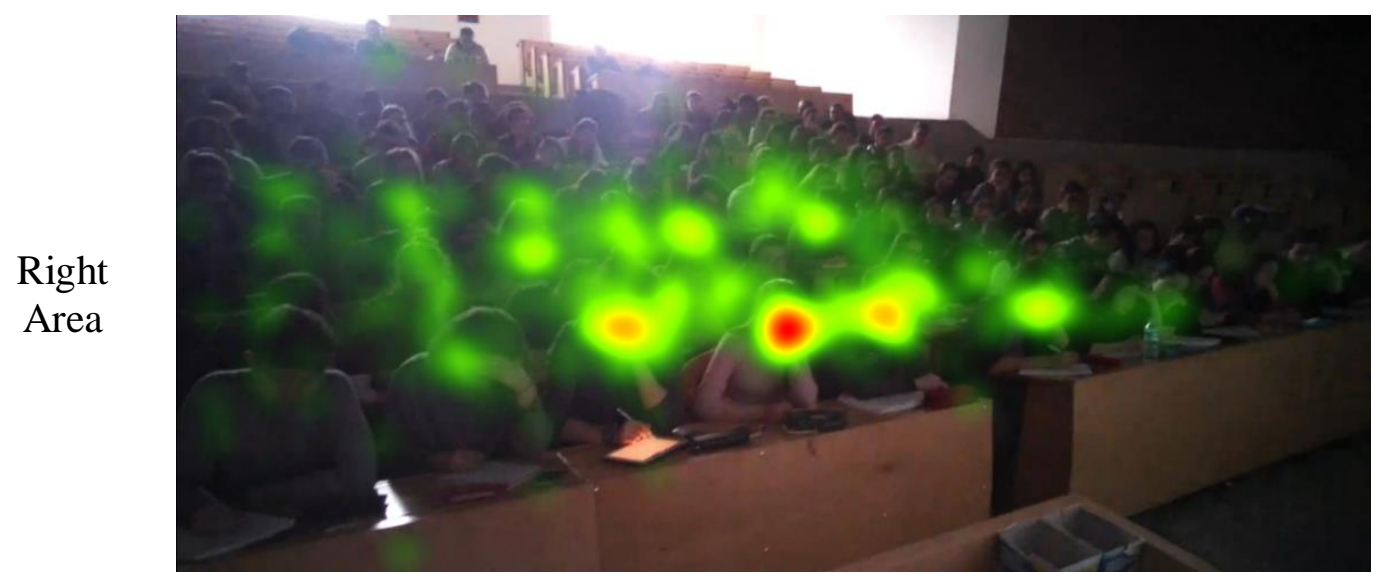

Figure 4-15: Heatmap of Visual Attention

The participant tried to fixate evenly across the students during the first 15 minutes of the course; he spent $54 \%$ of the time making eye contact with the students sitting at the front rows; in contrast, he spent $46 \%$ of the time on the students sitting at the back rows (see Figure 4-16). However, this result dramatically changed after the first 15 minutes of the course. He ignored the students sitting at the back rows after the first part of the course. Concerning this, in the RTA session, he commented that after the first 15 minutes, the students who sat at the back rows could not focus and they started to play with their smart phones, so the faculty member started to ignore the students at the back of the classroom. Besides, he commented that it is very difficult for him to fixate evenly across the classroom environment as the classroom environment is too large. In the first week RTA session, he had a chance to observe his false behaviors during teaching and tried to improve them in the next weeks. 


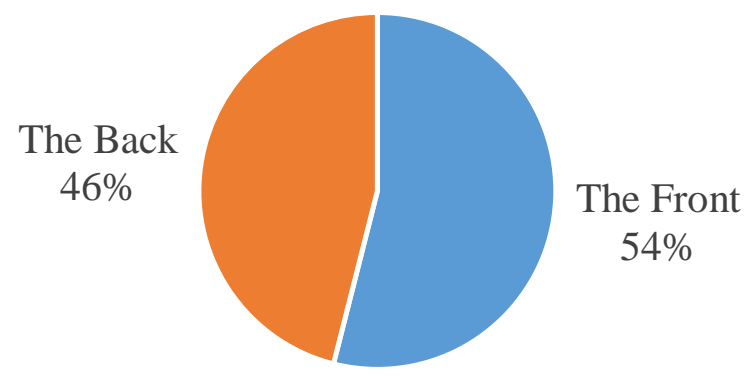

Figure 4-16: \% of Total Time Spent on Back and Front in the 1st Part of the Course

\subsubsection{The Second Week}

In the $2^{\text {nd }}$ week, the course duration lasted for approximately 30 minutes. As is the case with the first week, the wearable eye tracker and video camera were employed to get the data. The outcomes of the $2^{\text {nd }}$ week showed that the faculty member attempted to make more eye contact with the students and reduce the time looking at the computer, compared to the first-week results. In the first week, the percentage of the total time spent on the students was 64\% (see Figure 4-13). This ratio increased to 77\% (see Figure 4-17). Besides, the total time spent on the computer decreased from $34 \%$ to $22 \%$ when the first and second-week results were compared to each other. In the RTA session, he said that he tried to make more eye contact with the students. From this point of view, it seems that he attempted to change visual attention by getting feedback from the eye tracker and video camera data.

Another point was the interaction with the front and back rows of the classroom. The second-week results showed that his visual attention across the front and back rows did not change. As such in the first week, the percentage of the total time spent on the front and back rows were 95\% and 5\% respectively (see Figure 4-18). The participant aimed to distribute his gazes evenly across students sitting at the middle rows of the classroom. This was interpreted by him as a result of the position of the teacher's chair which was located right across the middle area of the classroom. Therefore, he fixated 
more evenly across the middle rows, compared to the right rows of the classroom (see Figure 4-19). He made eye contact with the students sitting at the back of the right rows of the classroom quite a little. In a similar to all course, in the three-time interval of the course, he fixated on the front rows too much.

Consequently, the participant made more eye contact with the students, which can be interpreted as an improvement. However, the total time spent on the front and back rows did not change in the $2^{\text {nd }}$ week.

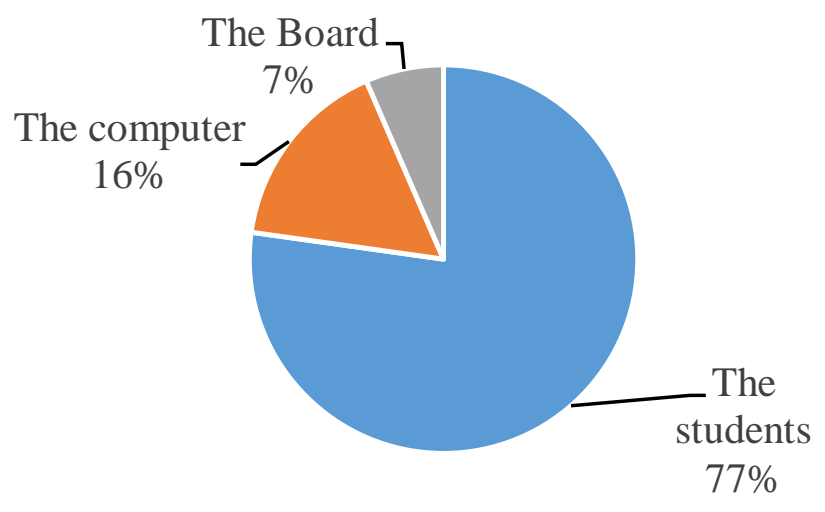

Figure 4-17: \% of Total Time Spent on the AOIs

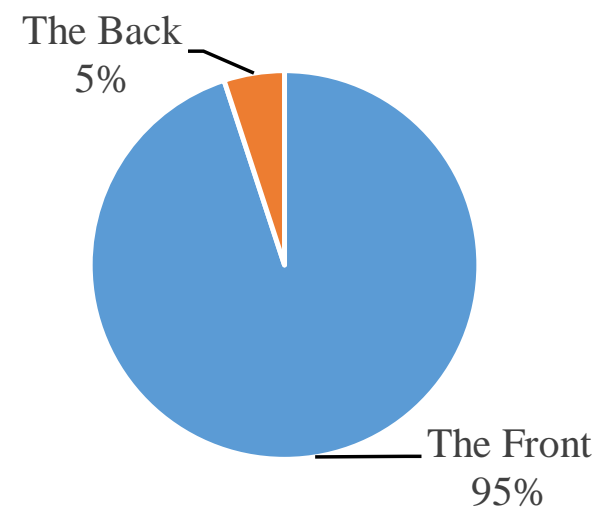

Figure 4-18: \% of Total Time Spent on the Front and Back 

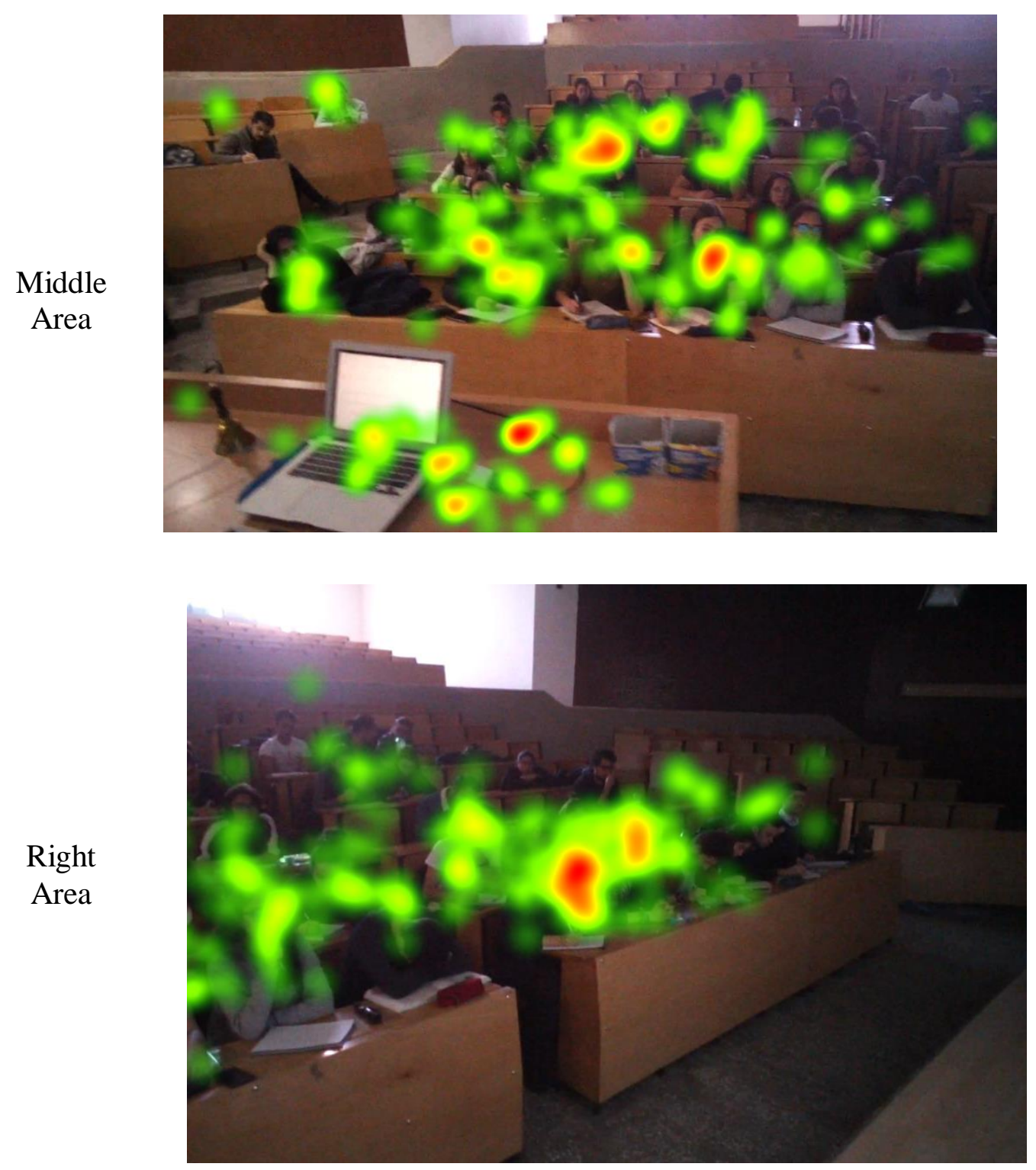

Figure 4-19: Heatmap of Visual Attention Across the Middle and Right

\subsubsection{The Third Week}

As such in the first and second week, the faculty member spent more time looking at the students, with a ratio of $47 \%$. The second most spent time was on the computer, with $38 \%$. The participant interacted with the board least. Comparing the pie charts of the second and third week (see Figure 4-17 \& Figure 4-20), it is seen that the percentage of the total spent time on the students decreased from $77 \%$ to $47 \%$. On the 
contrary, the time he spent on the computer increased from $16 \%$ to $38 \%$. Compared to the first and second-week results, it is seen that he increased the time spent on the students.

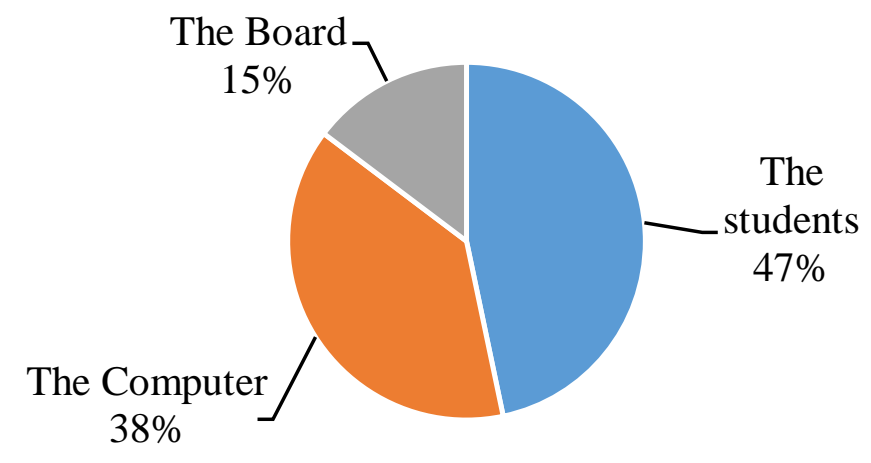

\section{Figure 4-20: \% of Total Time Spent on the AOIs}

During the three weeks, eye-tracking technology guided the participant to increase the amount of eye contact with the students sitting at the back of the classroom. Similar to the first and second week, the third-week results demonstrated that the participant spent most of the time on the students sitting at the front rows, with $87 \%$ (see Figure 4-21). However, compared the third week to the first and second week, the percentage of the total time spent on the back of the classroom increased from $5 \%$ to $13 \%$. Besides, differently from the first week (Figure 4-15), it is seen that in the second (Figure 4-19) and third week (Figure 4-22), the participant aimed to distribute his gazes evenly across the students sitting at the middle rows of the classroom in the second and third week, which indicates an improvement. On the contrary, the participant fixated on the right back of the classroom too little. In the three-time interval of the course, he fixated more on the front rows. His visual attention did not change between the parts of the course. 


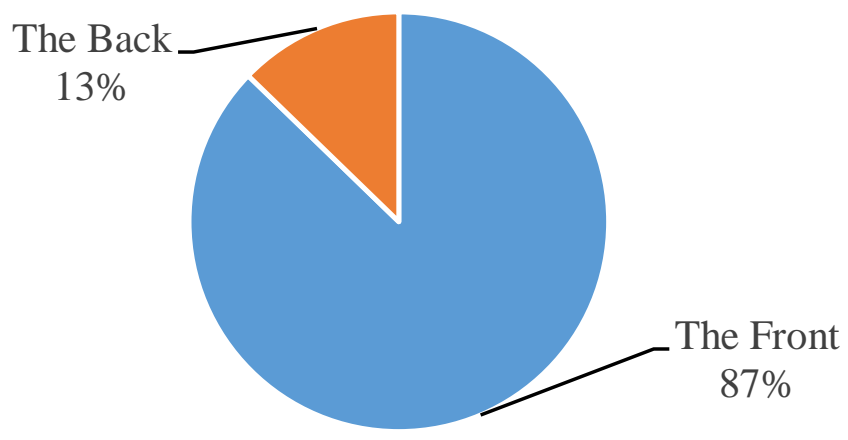

Figure 4-21: \% of Total Time Spent on the Front and Back

Middle

Area

Right

Area
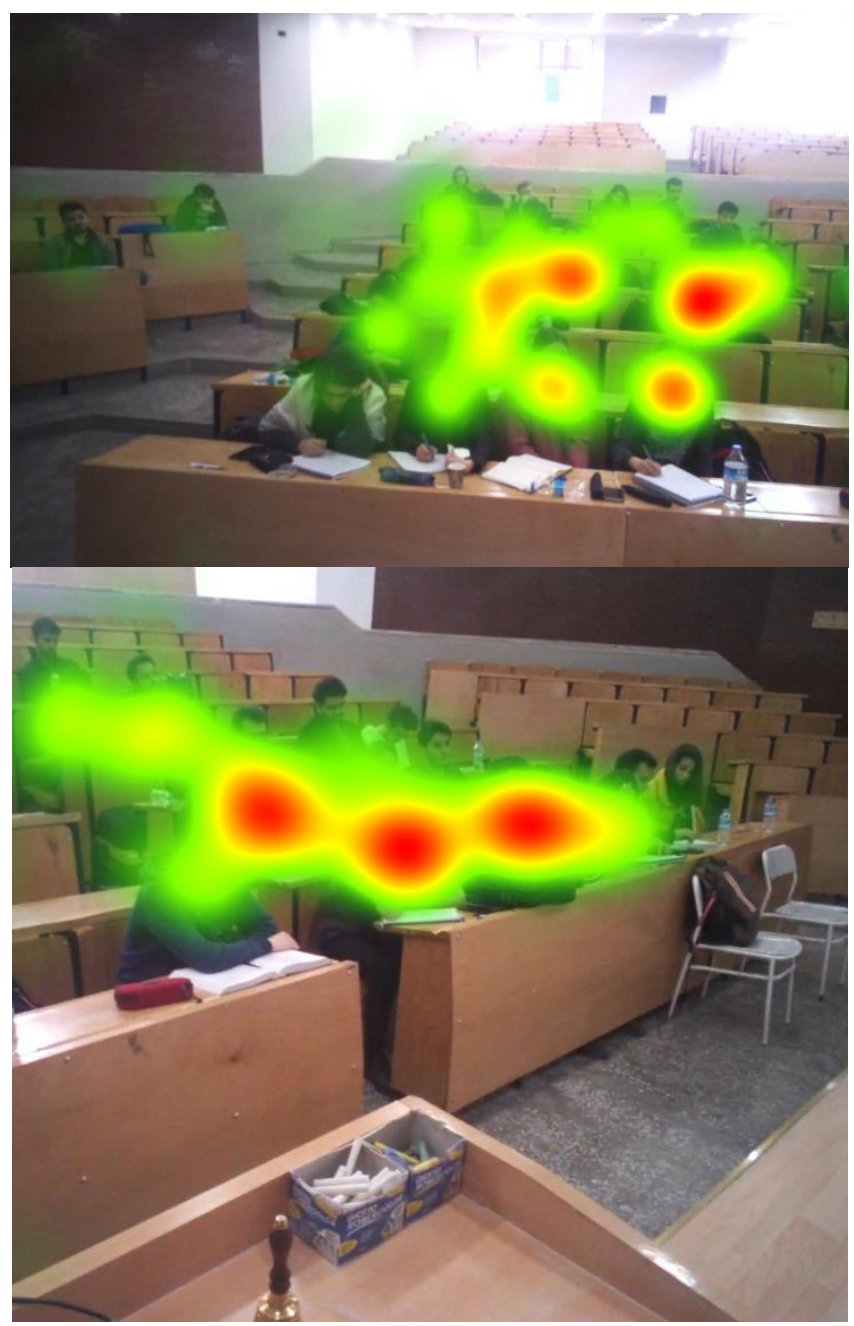

Figure 4-22: Heatmap of Visual Attention Across the Middle and Right 


\subsubsection{Interview with the $2^{\text {nd }}$ Participant}

A short interview session was conducted with the $2^{\text {nd }}$ participant. The participant noted that after observing the first-week data results of eye-tracking and video camera, he aimed to enhance his visual behaviors about classroom management. For instance, he wanted to distribute his gazes evenly across the students. Besides, it was told to the participant that he showed more evenly visual attention across the classroom during the first 15 minutes of the course. Concerning this, the participant commented that after the first part of the course, the questions were coming from the students sitting at the front rows, so he focused on the front rows in the second and third part of the lesson. The participant also mentioned that eye-tracking and video camera records raised his awareness. He said, "I observed that I haven't implemented what I have to do about classroom management." For instance, the participant said he was aware of that he was ignoring the back rows, but he did not expect to ignore the back of the classroom so much. Regarding the use of eye tracker in classroom management, he believes that eye-tracking methodology will be a useful tool to assess and train teachers about classroom management since "eye tacking raises awareness", he said. About the wearable eye tracker, he said that it prevented his field of vision, but he thinks that it does not have any effect on his teaching performance. Concerning the video camera results, he mentioned that he had changed his position while writing on the computer. According to him, he ignores the back rows because of the position while using the computer. Therefore, he thinks that video camera results also gave meaningful feedback about gestures he performed in the courses.

\subsection{Weekly Comparison of the Data}

Table 4- 1 shows weekly comparison of the $1^{\text {st }}$ participant's data. On the other hand, Table 4-2 demonstrates weekly comparison of the $2^{\text {nd }}$ participant's data. 
Table 4-1: Weekly Comparison of the 1st Participant's Data

\begin{tabular}{|c|c|}
\hline \# & Distribution of Visual Attention Across Classroom Environment \\
\hline 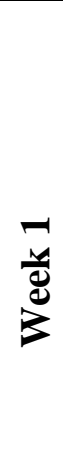 & $\begin{array}{l}\text { The Outside } \\
\text { The students } \\
90 \%\end{array}$ \\
\hline$\frac{N}{d}$ & $\begin{array}{l}\text { The Slides \& Board } \\
\text { The Computer The Outside } \\
7 \% \\
\text { The Students } \\
84 \%\end{array}$ \\
\hline m & $\begin{array}{l}\text { The Outside_ The Slides \& Board } \\
\text { The Students } \\
87 \%\end{array}$ \\
\hline \# & Visual Attention Across Back and Front Rows of the Classroom \\
\hline
\end{tabular}




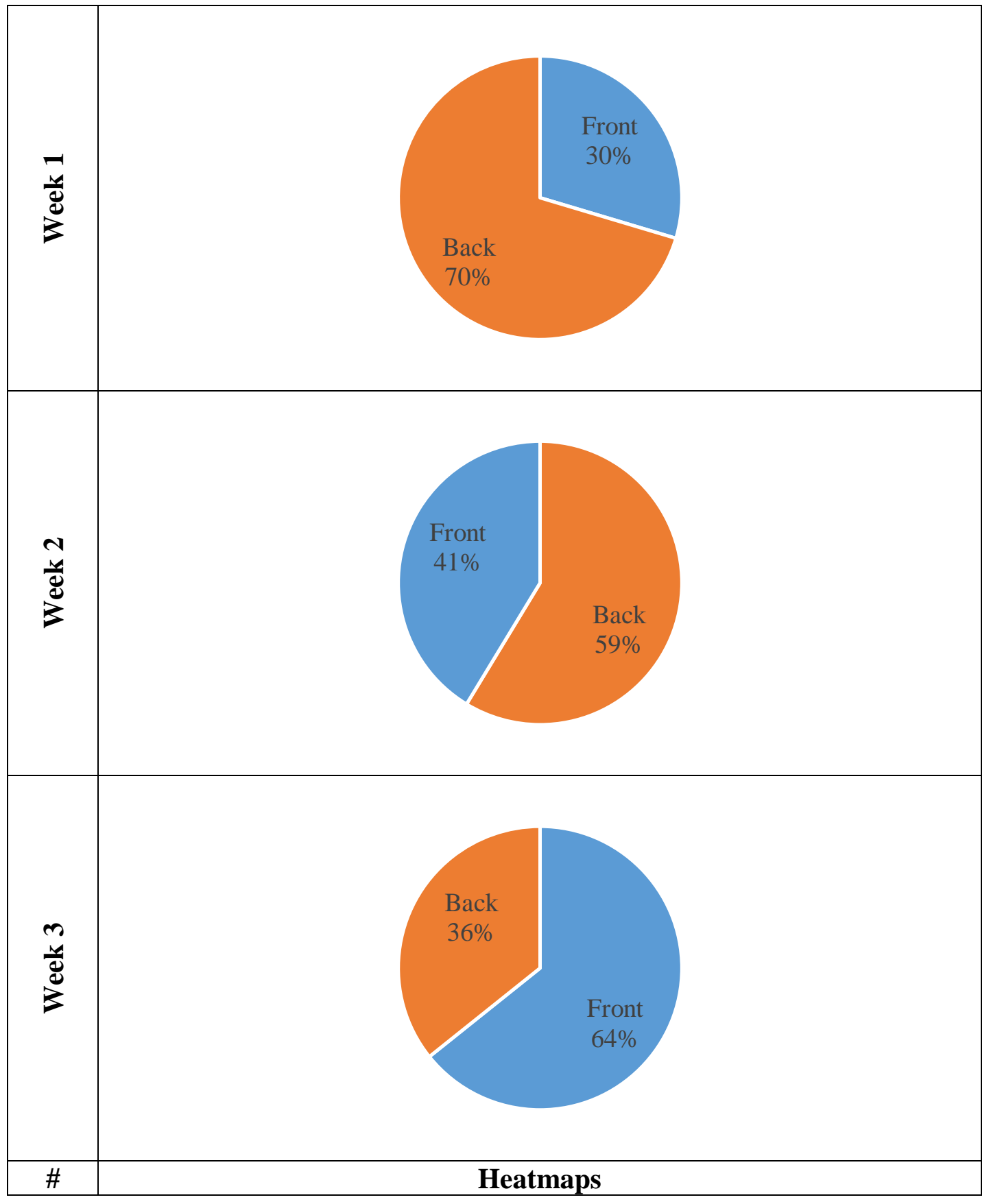




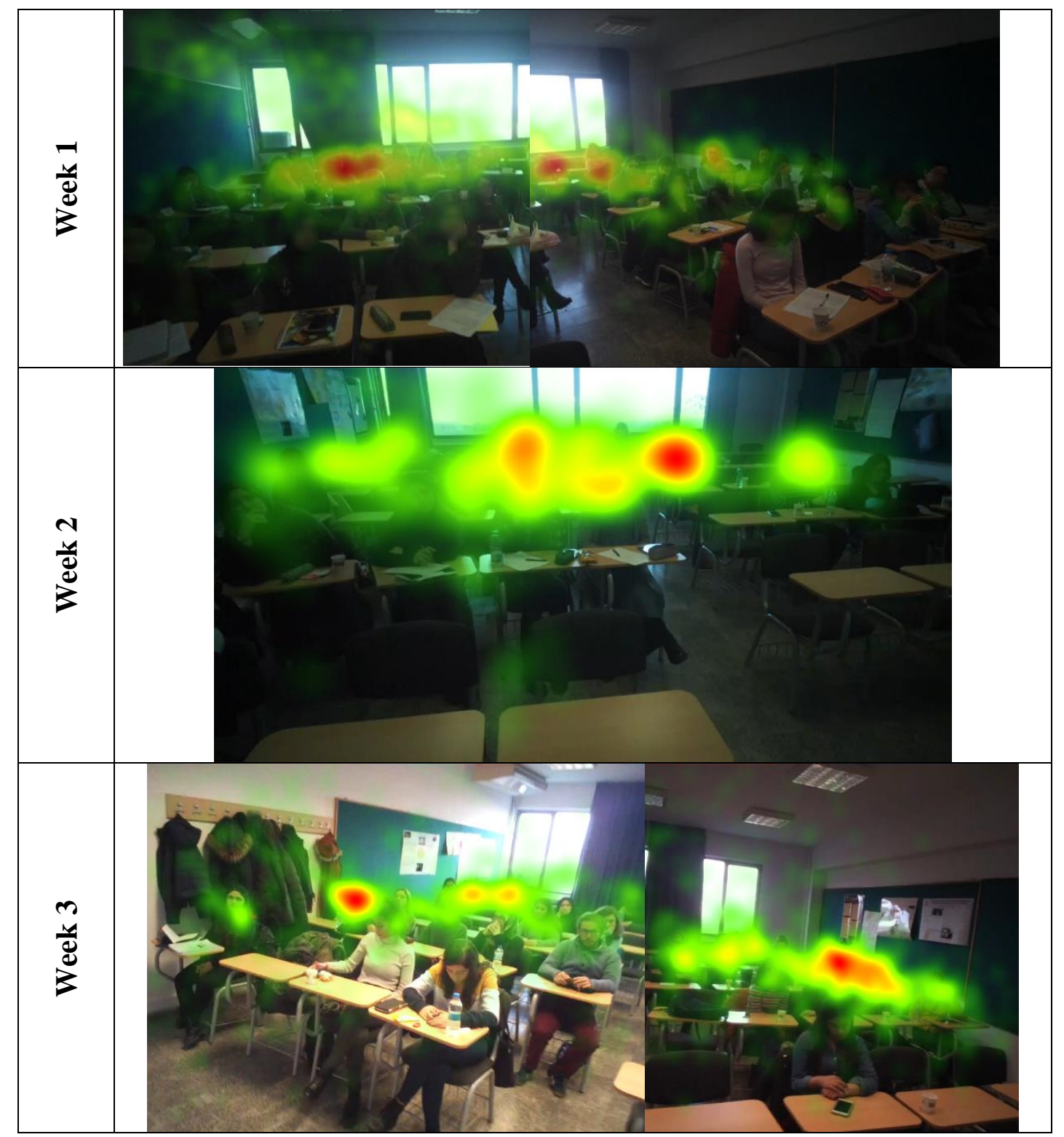


Table 4-2: Weekly Comparison of the 2nd Participant's Data

\begin{tabular}{|c|c|}
\hline \# & Distribution of Visual Attention Across Classroom Environment \\
\hline$\frac{-7}{8}$ & $\begin{array}{l}\text { The board } \\
2 \% \\
\text { The computer } \\
34 \%\end{array}$ \\
\hline 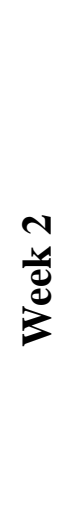 & $\begin{array}{l}\text { The Board } \\
\text { The computer }\end{array}$ \\
\hline 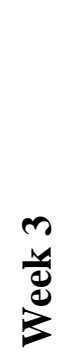 & The students \\
\hline \# & Visual Attention Across Back and Front Rows of the Classroom \\
\hline
\end{tabular}




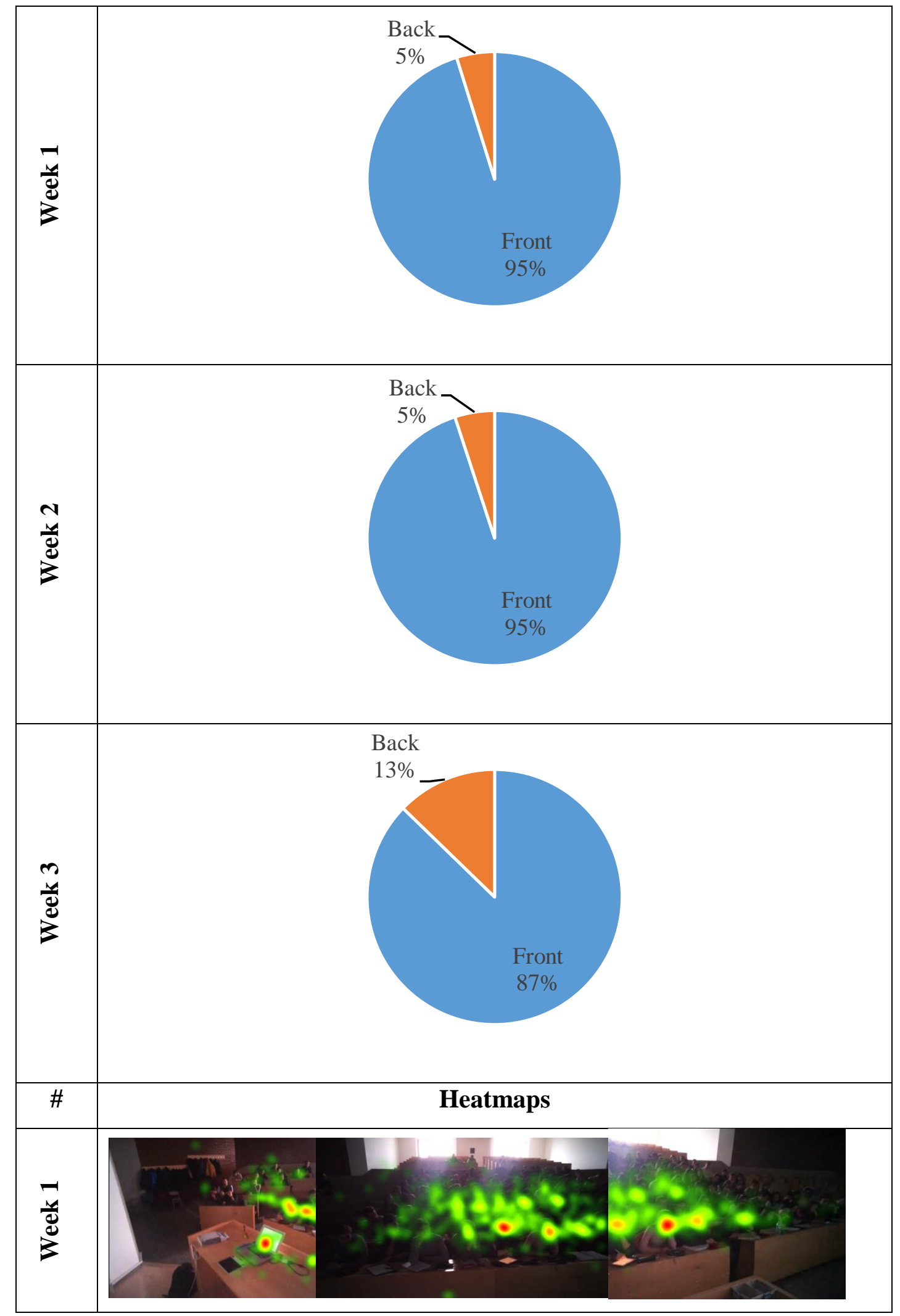




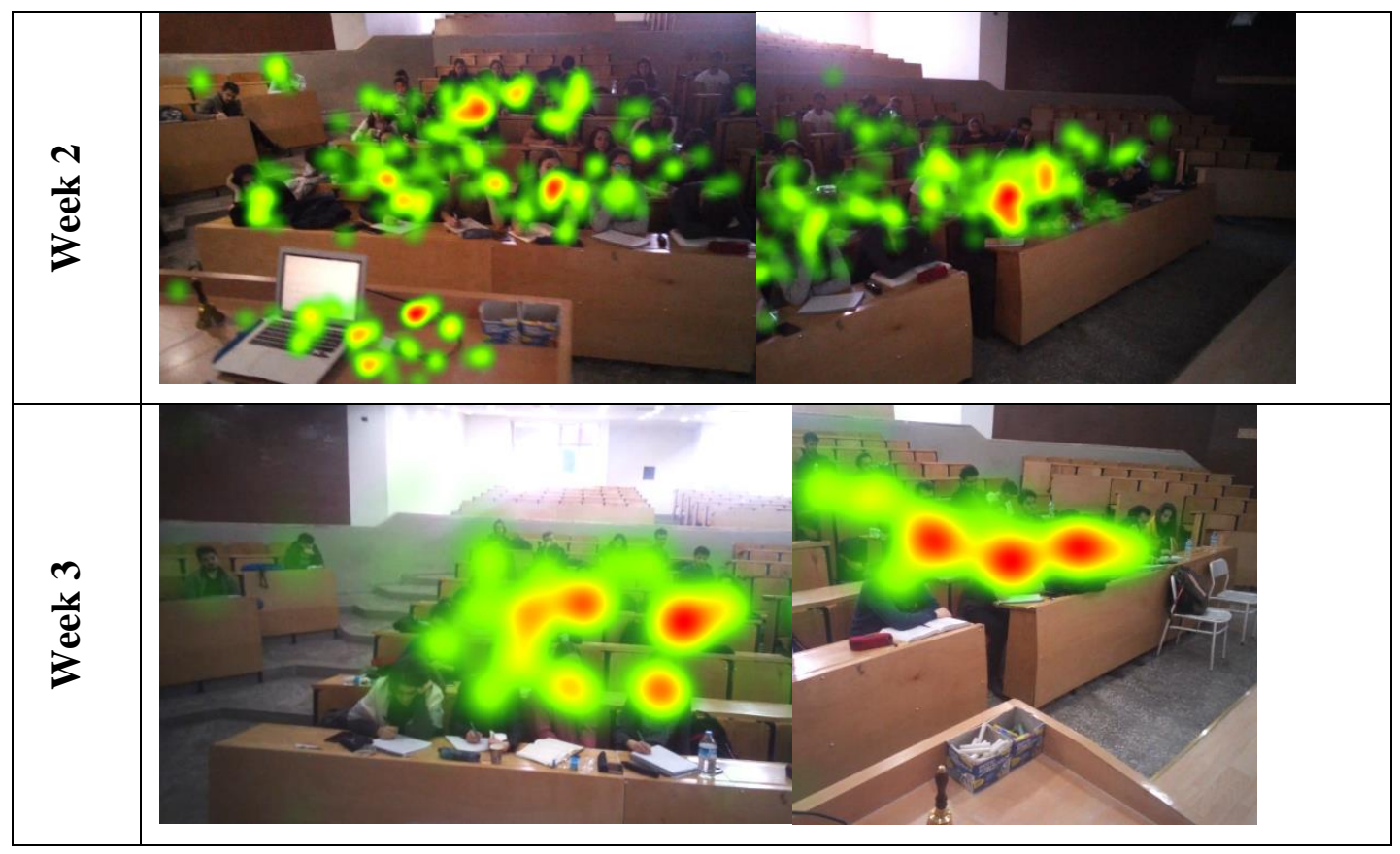

\subsection{Summary of the Results}

The wearable eye tracker was successful in capturing eye movements of the participants in the classroom styles including the auditorium and traditional classroom. As a result, classroom management performance could be successfully assessed by analyzing the faculty members' visual behaviors. That is, it was seen that eye-tracking data could provide them with constructive feedback about their classroom management. Distribution of their visual attention across the pupils and classroom materials were analyzed by the software of the wearable eye tracker. Eyetracking data was supported by Retrospective Think Aloud (RTA) sessions and interviews.

The eye-tracking and video camera data were successful in improving non-verbal behaviors such as eye contact and gestures of the faculty members. The eye-tracking data showed that in the first week, both of the participants did not allocate their visual attention evenly across the pupils. Consequently, after the first week, it was aimed for the participants to distribute their gazes evenly across the pupils. The weekly comparison of heatmaps of the $1^{\text {st }}$ participant showed that the $1^{\text {st }}$ participant could not 
show a market improvement about his distribution of gazes. However, weekly comparison of heatmaps of the $2^{\text {nd }}$ participant demonstrated that the $2^{\text {nd }}$ participant tried to distribute their gazes more evenly across the pupils after he had the chance to observe his eye-tracking data and analysis results of his eye movements in the first week. Video camera data also supported this improvement. Besides, the 1st participant's visual attention across the front and back rows of the classroom did not distribute evenly for three weeks. The same result was valid for the 2 nd participant. However, in the $2^{\text {nd }}$ week, the $1^{\text {st }}$ participant tried to distribute his gazes more evenly. Similarly, in the $3^{\text {rd }}$ week, the $2^{\text {nd }}$ participant tried to make more eye contact with the back rows of the classroom. Regarding the participants' visual attention across the classroom materials, eye-tracking data showed the $1^{\text {st }}$ participant spent a bit much time looking at the outside of the classroom (the windows). In the RTA session, the participant also stated that he was aware of spending a bit much time on the outside. After the first week, it was targeted to decrease time. Spending time on the outside has decreased in the third week, compared to the first and second week. However, the faculty member reported that this might be because of the curtain in the RTA session. Besides, it was observed that the $2^{\text {nd }}$ participant interacted with the computer a bit more in the first week. In the second week, the duration of interacting with the computer has considerably decreased, so the duration of interacting with the students has increased. However, in the third week, interaction with the computer and board has increased. Regarding interview results, both of the participants considered that the eye-tracking data shared meaningful feedback with them about their classroom management performance. More importantly, they think that eye-tracking methodology could be employed to evaluate and improve classroom management skills, especially eye contact.

In conclusion, the eye-tracking and video camera data were successful in assessing the faculty members' classroom performance during the three weeks. They presented meaningful feedback about non-verbal behaviors such as visual attention and gestures. 
They also made contributions to the improvement of the participants' visual attention. Interviews and RTA sessions play a significant role in supporting eye-tracking data. 



\section{CHAPTER 5}

\section{DISCUSSION AND CONCLUSION}

In this chapter, the findings collected by eye-tracking methodology, video camera, and interview are interpreted and discussed. Besides, this chapter concludes the findings and includes the limitations of the study and recommendations for future studies.

\subsection{Discussion}

Especially wearable eye trackers have become an important tool for researchers who want to assess and improve human performance in the real-world environment by analyzing the visual attention. Thus, wearable eye trackers are practical for those who want to study naturalistic viewing behavior (MacInnes et al., 2018). Meanwhile, in the current study, wearable eye-tracking technology was employed to assess and improve classroom management performance by addressing the faculty members' visual behaviors. The objective of the current study is to show how a wearable eye tracker can be used to improve classroom management skills. The results have shown that wearable eye tracker can be used for improving teaching behaviors of the faculty members, which help them to improve their classroom management. Besides, supporting eye-tracking data with video camera recordings provide a wealth of information about gestures in the classroom environment, which contribute to the improvement of the participants' classroom management. Eye-tracking results were also supported by verbal reports collected in the RTA sessions. According to Van den Bogert et al. (2014), eye-tracking data needs the support of the other data sources such as verbal reports. 


\subsubsection{Faculty Members' Visual Attention Across the Students}

At the beginning, it was observed that the participants did not distribute their visual attention evenly across the students. Some eye-tracking studies indicated that the experienced teachers distribute their gazes more evenly across the pupils, compared to the novice teachers (Cortina et al., 2015; Van den Bogert et al., 2014). Therefore, it was aimed for the participants to allocate their visual attention more evenly across the pupils. In the first and second week, the $1^{\text {st }}$ participant's visual attention was mostly on the students sitting at the back rows. On the contrary, in the third week, he made more eye contact with the students sitting at the front rows. Consequently, the $1^{\text {st }}$ participant did not make progress in distributing his visual attention across the students equally. However, in the RTA sessions, the participant commented that he had changed his visual attention depending on the students' level. He said that students sitting at the back rows of the classroom are more likely to misbehave, so he fixated more at the back rows in the $1^{\text {st }}$ and $2^{\text {nd }}$ week. In the $3^{\text {rd }}$ week, misbehaviors like fiddling with smartphones could happen among the students sitting at the front rows, so he attempted to make more eye contact with those sitting at front rows. In contrast, the $2^{\text {nd }}$ participant ignored looking at the students fiddling with their smartphones. He did not use eye contact technique to prevent the students from fiddling with their smartphones. The $2^{\text {nd }}$ participant should have used eye contact to gain the attention of the students fiddling with their smartphones to the course topic. In the Özben (2010) study, experienced teachers frequently employed eye contact technique to cope with misbehaviors in the classroom. In Benzer's (2012) study, $82 \%$ of the teachers who participated in the survey stated that they employ eye contact technique to alert students about their misbehaviors. Similarly, in the Boysen (2012) study, college students want their teachers to show immediate actions to prevent misbehaviors in the classroom environment. According to Hodge (1971), students who need more attention are likely to perform misbehaviors. Therefore, the teacher could make more eye contact with these students because eye contact would meet that need. Making direct eye contact with the students can help teachers to change students' behaviors 
(Upton \& Cook, 2004 cited in Khan et al., 2016). The $1^{\text {st }}$ participant did not ignore looking at other students; he just fixated on other students less. However, the $2^{\text {nd }}$ participant did not make eye contact with the students fiddling with their smartphones. It was aimed for the $1^{\text {st }}$ participant to distribute visual attention across the students equally because eye-tracking studies showed experienced teachers make eye contact with students evenly. Also, an experienced teacher should not look at only a specific group of the students while lecturing; teachers should make eye contact with students evenly (Palmer, 2009). In parallel to this, the $1^{\text {st }}$ participant employed eye contact as an effective tool to draw his students' attention to the course topic, so he tried to prevent misbehaviors that might occur. Furthermore, the course durations were divided into almost equal three parts. The results demonstrated that the $1^{\text {st }}$ participant tried to distribute his visual attention more evenly across the students at the beginning of the courses, compared to the second and third part of the courses. In the RTA sessions, it was understood that the differences of visual attention are due to the students; the faculty member made more eye contact with the students who cannot concentrate after the $1^{\text {st }}$ part of the course. Eye contact helps teachers to get students' attention to the topic, thus they become concentrated throughout the course (Moore, 2009 cited in Atta \& Ayaz, 2014).

As for the $2^{\text {nd }}$ participant, in the $1^{\text {st }}$ week, the $2^{\text {nd }}$ participant's visual attention showed that he made much more eye contact with the students sitting at the front rows, compared to the back rows. Differently from the case of the $1^{\text {st }}$ participant, heatmaps showed that he ignored looking at students sitting at back rows. This shows that the faculty member had a narrow view of the classroom. In the Van den Bogert et al. (2014) study, experienced teachers allocated their gazes more evenly across the pupils. So, they think that experienced teachers have a larger view of the class environment. A study also showed that novice teachers (pre-service teachers) did not allocate their gazes evenly over the pupils (Stürmer et al., 2017). Since auditorium is the largest classroom environment, performing effective classroom management is much more difficult in auditorium classroom-style than a traditional classroom environment. In 
the RTA session, the faculty member said that he had difficulty in making eye contact with many students. In Jerez et al. (2018) study, some professors had difficulties in creating a learning environment in a large classroom environment because they do not have effective communication skills. Therefore, using visual behaviors effectively in the auditorium is more important because auditorium is large and contains quite a lot of students. University students can be easily distracted because of the number of students. Hence, it is crucial to improve their communication strategies. Using eye contact properly helps faculty members to communicate with students efficiently (Benzer, 2012). In Zeki's (2009) study, university students consider teachers visual behaviors as a sign for keeping attention. Therefore, in the $2^{\text {nd }}$ and $3^{\text {rd }}$ week, it was targeted for the faculty member to distribute his gazes evenly across the pupils and have a larger view of the classroom. The participant distributed his visual attention more evenly especially on the middle area of the classroom, compared to the $1^{\text {st }}$ week (see Figure 5-1). Moreover, in the $1^{\text {st }}$ week, the participant almost ignored the right front rows, but in the $2^{\text {nd }}$ and $3^{\text {rd }}$ week, there was an improvement in the visual attention to the right area (see Figure 5-2). Generally, compared to the $1^{\text {st }}$ week, the $3^{\text {rd }}$ week results demonstrated that the participant tried to make more eye contact with back rows; the percentage of the total time spent on the back rows increased from 5\% to $13 \%$. Concerning the improvement of visual attention of the $2^{\text {nd }}$ participant across the students, it can be said that the faculty member's self-exploration contributed to this improvement in the RTA sessions. Eye tracker and video camera data shared informative feedback with the participant about non-verbal behaviors. Hence, he realized that he exhibited false behaviors in his gestures and visual attention. The video camera data allowed the participant to observe his physical movements during teaching. In the RTA and interview session, the faculty member said that after he saw his writing position in front of the computer by a video camera, he changed the position in the $2^{\text {nd }}$ and $3^{\text {rd }}$ week while writing on the computer, so he could fixate at the back rows and right area. Teachers' gestures in classroom have positive effects on students. Teachers can gain the attention of the students if they effectively use nonverbal behaviors while lecturing (Araya, Farsani, \& Hernández, 2016). Therefore, 
faculty members should attach importance to gestures in a classroom environment. Besides, the course durations were divided into three parts and analyzed for three weeks. The results indicated that as is the case with the $1^{\text {st }}$ participant, the $2^{\text {nd }}$ participant distributed visual attention across the students more evenly in the $1^{\text {st }}$ part of the course, compared to the $2^{\text {nd }}$ and $3^{\text {rd }}$ part of the course. The $2^{\text {nd }}$ participant said that this is because more questions were coming from the front rows. He also expressed that as some students sitting at back rows started to fiddle with their smartphones, he ignored looking at them. However, under this circumstance, the $1^{\text {st }}$ participant employed eye contact technique to get the students' attention to the course. As stated by Palmer (2009), the teacher should not address only a group of students. Teachers should use eye contact to prevent disruptive behaviors. In addition, the teacher must employ eye contact to maintain students' motivation (Khan et al., 2016). In the RTA sessions, the $2^{\text {nd }}$ participant reported that he tried to change problematic behaviors. For instance, he said that by video camera recordings, he changed his lecturing position in front of the computer, so he could also fixate on the back of the classroom. This improvement may have positive effects on the pupils. Training teachers about their non-verbal behaviors have positive impacts on student engagement and attention (Woolfolk \& Brooks, 1985, as cited in Bettencourt et al., 1983). Similarly, in the Restuningrum (2018) study, it was highlighted that the teacher's position in the classroom plays a critical role in sending the message to pupils. Therefore, in order to deliver the right message to students, teachers should arrange their position in the classroom by taking classroom activities and content of course into consideration.

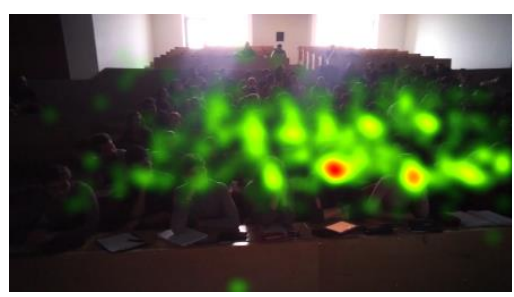

First Week

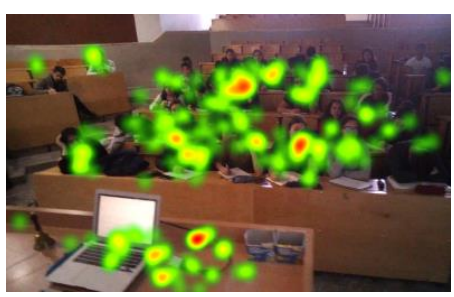

Second Week

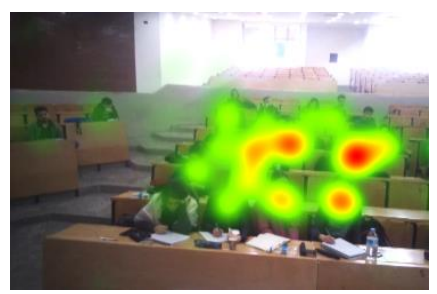

Third Week

Figure 5-1: Comparison of the 2nd Participant's Heatmaps on the AOI (Middle Area) 


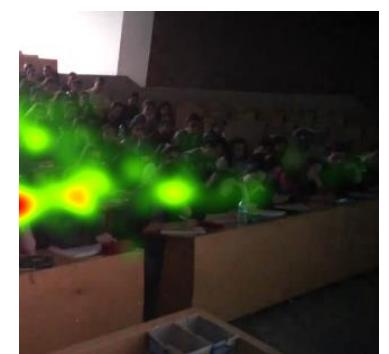

First Week

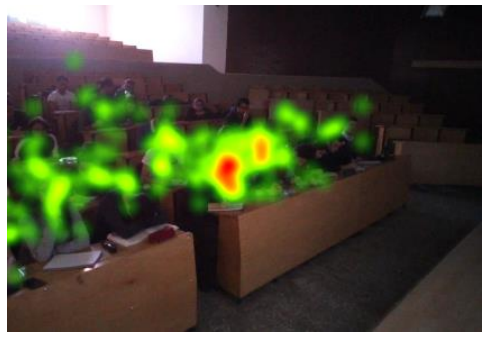

Second Week

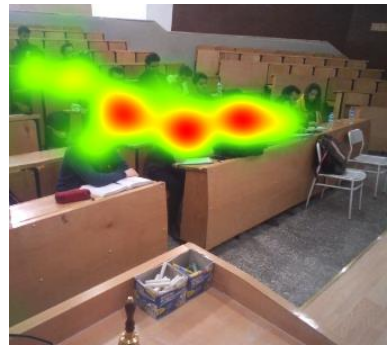

Third Week

Figure 5-2: Comparison of the 2nd Participant's Heatmaps on the AOI (Right Area)

\subsubsection{Faculty Members' Visual Attention Across the Classroom}

To analyze, the traditional classroom environment was divided into the four Area of Interests (AOIs) including the students, the computer, the board, and the outside. The visual attention of the $1^{\text {st }}$ participant across the AOIs was investigated. Expectedly, the $1^{\text {st }}$ participant spent most of the lesson time across the students for the three weeks. The first-week results showed that the participant spent a bit much time on the outside. In the RTA session, the faculty member accepted that he was distracted because of movements of the outside. This resulted from the windows of the classroom. Removing windows from classrooms cannot be a solution because windows allow sunlight to enter into the classroom and this affects individuals' performance positively (Tanner, 2008). However, poorly designed windows can distract visual attention (Benya, 2001). Therefore, designs of windows and positions in classrooms are important for teaching and learning. Consequently, eye-tracking results shared meaningful feedback with the $1^{\text {st }}$ participant about how he distributed his visual attention across the classroom environment. Regarding the $2^{\text {nd }}$ participant, the auditorium was divided into three AOIs (the students, the computer and the board). Visual behaviors on the AOIs were analyzed. Expectedly, the first-week results showed that the teacher spent most of the time on the students. On the other hand, the total time spent on the computer was high because the participant preferred writing on the computer instead of writing the board. However, the video records showed that at some intervals of the course, he was lecturing without raising his head and looking at the students. As a result, this prevented him from making eye contact with especially 
the students sitting at the back rows. In the RTA session, the faculty member told that he was going to decrease duration of interacting with the computer. In the second week, the duration spent on the computer decreased. Thus, the teacher spent more time on the students increased. Contrary to the second week, the percentage of total time spent on the computer and board increased in the third week. Between the $1^{\text {st }}$ and $2^{\text {nd }}$ week, there is an improvement, but in the third week, a regression happened. Having look at the video records shows that the participant did more problem-solving activities on his computer in the $3^{\text {rd }}$ week, which might have caused that regression.

\subsubsection{Participants' Thoughts About Wearable Eye Tracker}

Regarding the use of wearable eye trackers in classroom management, the faculty members think that wearable eye tracker can be more beneficial for the issue of classroom management. According to them, wearable eye trackers share meaningful feedback about classroom management. Wearable eye tracker is a promising tool that can be used in classroom research, but more importantly, it can be used as a feedback tool to develop teacher performance (Cortina et al., 2015). The $1^{\text {st }}$ participant mentioned that wearable eye tracker can be more useful for those who haven't got pedagogical training about teaching skills, especially including classroom management. In higher education, teachers have almost no pedagogical training, so eye-tracking methodology can make a significant contribution to their classroom management performance. The $2^{\text {nd }}$ participant also considers that wearable eye tracker as a tool to train teachers about classroom management since it gives information about visual perception in relation to classroom management. According to Vieira and Neto (2016), universities need to develop new formal opportunities for teachers to give feedback on their practices because teachers in higher education are not equipped with pedagogical information. In the Benzer (2012) study, the teachers who participated in the survey stated that they haven't got training about non-verbal behaviors in university education. Thus, eye-tracking can be a tool for universities and schools to improve faculty members or teachers' classroom management performance. Brown and Atkins (2002) asserted that effective teaching skills can be 
obtained and enhanced. Therefore, it is very important for departments to develop, observe and evaluate in-class teaching. The $1^{\text {st }}$ participant also thinks that eye-tracking can be a more meaningful tool if it is integrated with video camera data or other methods. This statement is valid because this study also showed that eye-tracking data could be more meaningful if it was supported by other methods. The $2^{\text {nd }}$ participant changed writing position in front of the computer by video records. Besides, Van den Boger et al. (2014) claimed that the interpretation of eye-tracking data needs a merge with the data collected by the other sources like verbal reports or timestamps.

\subsection{Conclusion}

This study showed that wearable eye tracker can be used to evaluate classroom management performance in real-world classrooms. The wearable eye tracker gave the participants informative feedback about their classroom management performance, so they could change some false behaviors. Wearable eye tracker helped the participants to improve their visual attention across the students during the courses. Also, by eye-tracking data and video recordings, the faculty members received feedback about their gestures. Consequently, eye-tracking technology provided them with a great opportunity to see how they lecture. At the same time, eye-tracking shared valuable information about the design of the classroom environment. The wearable eye tracker demonstrated the windows can distract the attention of the faculty members. Large windows standing right across faculty members can distract the attention. In the design of the classrooms, the size of the windows should not be disturbing. The windows should not be placed right across teachers while they are lecturing. The windows should be well-designed and put in the most suitable part of the classroom.

Moreover, the current study and literature demonstrated that eye-tracking methodology can be used to assess classroom management. Research in the literature especially focused on K-12 teachers' visual attention. The researchers compared the expert teachers' visual attention with the novices' one. Differently from the research 
in the literature, this study showed how to improve classroom management performance in higher education with the help of eye-tracking methodology. In higher education institutions, Teaching and Learning Centers (TLCs) can employ eye trackers as an assistive tool to assess instructors' classroom management performance and share useful feedback about their performance. In TLCs, this method can be used to train, especially new faculty members. Therefore, the adaption of them to the teaching profession can be accelerated. TLCs can also support eye-tracking data with peer evaluation, interview, classroom management scale, course evaluations, or video recordings because eye-tracking data can share more constructive feedback if it is integrated with other methods. Moreover, eye-tracking method that is supported with video recordings can be used by educators who train new faculty members or preservice teachers about classroom management. The use of both an eye tracker and a video camera can enhance especially non-verbal behaviors of teacher. New faculty members and pre-service teachers can have difficulties in comprehending classroom management techniques and wearable eye tracker may contribute to the development of classroom management skills in a short time with its constructive feedback. Besides, Instructional Technology Support Centers may employ wearable eye tracker to assess the interaction of instructors with technological materials in the classroom. Similarly, in the European University Association (2019) report, it is recommended that support centers for teachers are actively involved in assessment and observation process. Furthermore, in the European University Association (2019) report, it is suggested that higher education institutions and TLCs may develop new methods for teaching and learning. Also, in that study, it is stated that teaching improvement should be based on a systematic approach. Eye-tracking methodology can play a significant role in teaching enhancement in the systematic approach. In a-teacher training, integrated with eye-tracking methodology, duration of the training should last for three weeks at least and they should be in consecutive weeks. Thus, teachers in training can easily remember problematic behaviors in Retrospective Think Aloud sessions and they try to enhance these behaviors in the following week. 
To conclude, it can be said that the wearable eye tracker was successful in evaluating classroom management performance. It showed how the faculty members distributed their visual attention across the classroom environment. In addition, eye-tracking technology in this study contributed to the improvement of classroom management performance in some matters. According to the interview results, eye-tracking technology can be a promising tool in evaluating classroom management and giving informative feedback as well.

\subsection{Limitations and Recommendations for Future Research}

In the current study, there are some limitations. First of all, wearing an eye tracker for a long period can disturb the participants. In the interview session, both of the participants already reported it. Although the faculty members stated that the eye tracker did not have any effect on their performance, it may prevent them from showing actual performance. Secondly, eye-tracking data could not be gathered in the consecutive weeks because of the eye tracker problems. If the data were gathered in the following weeks and interpreted by the participants as long as gathering it, eyetracking could have made more contribution to the improvement of classroom management performance. Thirdly, while eye-tracking software was doing automatic mapping on pictures of the classroom environment, some missing and incorrect codes happened. These codes were tried to be fixed manually. Furthermore, since the participants were aware of the fact that their eye movements and gestures were recorded, they might have attempted to show their best classroom management performance, which is known as novelty effect. In addition, the $1^{\text {st }}$ group of data were acquired. Then, the second group of data were collected. The experience of collecting the first group of data may have influenced the researcher's performance while obtaining the second group of data. The researcher might have showed a better performance during the collection of the second group of data. Therefore, this may be the reason for getting clearer answers to the interview questions in the second session. Finally, changes in the number of students may affect the faculty members' actual 
performance. For instance, in the auditorium, the number of students significantly decreased in the $3^{\text {rd }}$ week.

For future studies, this study can be conducted with more participants in higher education institutions. Moreover, this study can be repeated in K-12 level because teachers also have difficulties in using non-verbal behaviors like eye contact effectively. In addition, it is recommended that the data are gathered in the following weeks, hence participants can remember eye-tracking results and comments that made in the RTA sessions more easily in the next lesson while teaching. Finally, to observe and report changes in teachers or faculty members' behaviors about classroom management, interview sessions or surveys can also be conducted with students. This also helps to support eye-tracking and verbal report data. 



\section{REFERENCES}

Akteke Öztürk, B., Arı, F., Kubuş, O., Gürbüz, T., \& Çağıltay, K. (2008). Öğretim teknolojileri destek ofisleri ve üniversitedeki rolleri. Akademik Bilişim Bildiri Kitapçı̆̆

Al-Hamdan, J. (2007). Higher education classroom management: Kuwait university students' views. college student Journal, 41(3), 572.

Al-Moteri, M. O., Symmons, M., Plummer, V., \& Cooper, S. (2017). Eye tracking to investigate cue processing in medical decision-making: A scoping review. Computers in Human Behavior, 66, 52-66.

Araya, R., Farsani, D., \& Hernández, J. (2016, September). How to Attract Students' Visual Attention. In European Conference on Technology Enhanced Learning (pp. 30-41). Springer, Cham.

Atta, M. A., \& Ayaz, M. (2014). Use of Teachers' Eye Contact in the Classroom and Its Effect on the Speculative Execution of Students at Primary School Level: A Gender Based Study. Gomal University Journal of Research, 30(7).

Ball, D. L., \& Forzani, F. M. (2009). The work of teaching and the challenge for teacher education. Journal of Teacher Education, 60(5), 497-511. 
Barati, L. (2015). The Impact of Eye-contact between Teacher and Student on L2 Learning. Journal of Applied Linguistics and Language Research, 2(7), 222-227.

Baxter, P., \& Jack, S. (2008). Qualitative case study methodology: Study design and implementation for novice researchers. The qualitative report, 13(4), 544-559.

Benya, J. R. (2001). Lighting for schools. Washington, DC: National Clearinghouse for Educational Facilities. Retrieved from http://www.ncef.org/pubs/lighting.pdf

Benzer, A. (2012). Teachers' opinions about the use of body language. Education, 132(3).

Bloom, L. A. (2008). Classroom management: Creating positive outcomes for all students. Prentice Hall.

Borowsky, A., Shinar, D., \& Oron-Gilad, T. (2010). Age, skill, and hazard perception in driving. Accident Analysis and Prevention, 42(4), 1240-1249.

Boysen, G. A. (2012). Teacher responses to classroom incivility: Student perceptions of effectiveness. Teaching of Psychology, 39(4), 276-279.

Breen, C. J., Bond, R., \& Finlay, D. (2014). An evaluation of eye-tracking technology in the assessment of 12 lead electrocardiography interpretation. Journal of Electrocardiology, 47(6), 922-929. 
Brown, G., \& Atkins, M. (2002). Effective Teaching In Higher Education. Taylor \& Francis e-Library.

Chandra, R. (2015). Classroom Management As a Base for Effective Teaching. Golden Research Thoughts, 4(11), 1-5.

Chetwood, A. S. A., Kwok, K. W., Sun, L. W., Mylonas, G. P., Clark, J., Darzi, A., \& Yang, G. Z. (2012). Collaborative eye-tracking: A potential training tool in laparoscopic surgery. Surgical Endoscopy, 26(7), 2003-2009.

Christophel, D. M. (1990). The relationships among teacher immediacy behaviors, student motivation, and learning. Communication education, 39(4), 323-340.

Clotfelter, C. T., Ladd, H. F., \& Vigdor, J. L. (2006). Teacher-student matching and the assessment of teacher effectiveness. Journal of human Resources, 41(4), 778820.

Coffey, M., \& Gibbs, G. (2000). Can academics benefit from training? Some preliminary evidence. Teaching in Higher Education, 5(3), 385-389.

Cortina, K. S., Miller, K. F., McKenzie, R., \& Epstein, A. (2015). Where Low and High Inference Data Converge: Validation of CLASS Assessment of Mathematics Instruction Using Mobile Eye-tracking with Expert and Novice Teachers. International Journal of Science and Mathematics Education, 13(2), 389-403. 
Crossman, A. (2018). Understanding Purposive Sampling. Retrieved from June 18, 2019, https://www.thoughtco.com/purposive-sampling-3026727

Çağıltay, K., Yıldırım, S., Aslan, İ., Gök, A., Gürel, G., Karakuş, T., Saltan, F., Uzun, E., Ülgen, E., \& Yıldız, İ. (2007). Öğretim teknolojilerinin üniversitede kullanımına yönelik alışkanlıklar ve beklentiler: Betimleyici bir çalışma. Akademik Bilişim, 7.

Çağıltay, K. (2011). Üniversite ve Öğretim Teknolojileri Destek Ofisi:Mevcut Durum ve Türkiye Üniversiteleri için Gerekliliği, Uluslararası Yükseköğretim Kongresi:Yeni Yönelişler ve Sorunlar

Diaz-Piedra, C., Sanchez-Carrion, J. M., Rieiro, H., \& Di Stasi, L. L. (2017). Gazebased Technology as a Tool for Surgical Skills Assessment and Training in Urology. Urology, 107, 26-30.

Elias, M. J., \& Schwab, Y. (2006). From compliance to responsibility: Social and emotional learning and classroom management. Handbook of classroom management: Research, practice, and contemporary issues, 309-341.

Etheridge, T. (2010). Assertive discipline and its impact on disruptive behavior (Doctoral dissertation). Retrieved from ProQuest Dissertations \& Theses database. (Publication No. AAT 3409180) 
European Commission, EACEA and Eurydice (2018). The European Higher Education Area in 2018: Bologna Process Implementation Report. Luxembourg: Publications Office of the European Union

European University Association (2019). Evaluation of learning and teaching: Thematic Peer Group Report. Belgium: European University Association asbl

European University Association (2019). Promoting a European dimension to teaching enhancement: A feasibility study from the European Forum For Enhanced Collaboration in Teaching (EFFECT) project. Belgium: European University Association asbl

Gaebel, M., \& Zhang, T. (2018). Trends 2018: Learning and Teaching in the European Higher Education Area. European University Association.

Ganser, T. (2001). Beginning Teaching in Jamaica: Challenges and Assistance. Kingston University, Jamaica.

Gibbs, G., \& Coffey, M. (2004). The impact of training of university teachers on their teaching skills, their approach to teaching and the approach to learning of their students. Active learning in higher education, 5(1), 87-100

Glaholt, M. G. (2014). Eye-tracking in the cockpit: a review of the relationships between eye movements and the aviators cognitive state (No. DRDC-RDDC2014-R153). Defence Research and Development Toronto (Canada). 
Goldhaber, D. (2002). The mystery of good teaching. Education next, 2(1), 50-55.

Grossman, P., Hammerness, K., \& McDonald, M. (2009). Redefining teaching, reimagining teacher education. Teachers and Teaching: Theory and Practice, 15(2), 273-289.

Grushko, A. I., \& Leonov, S. V. (2014). The usage of eye-tracking technologies in rock-climbing. Procedia - Social and Behavioral Sciences, 146, 169-174.

Gürbüz, T., Arı, F., Akteke-Öztürk, B., Kubuş, O., Çağıltay, K., METU Instructional Technology Support Office: Accelerating Return on Investment Through elearning Faculty Development, submitted to 2. Uluslararası Gelecek İçin Öğrenme Alanında Yenilikler Konferansı 2008: e-Öğrenme, İstanbul, Türkiye, 27-29 Mart 2008.

Hains-Wesson, R. (2011). The impact of performance skills on students' attitudes towards the learning experience in higher education. Issues in Educational Research, 21(1), 22-41.

Hastings, S. L. (2010). Triangulation. Encyclopedia of research design, 3, 1538-1541.

Hanc, J. (2016, June 22). Teaching Professors to Become Better Teachers. Retrieved from https://www.nytimes.com/2016/06/23/education/teaching-professors-tobecome-better-teachers.html 
Heck, R. H. (2009). Article information:Teacher effectiveness and student achievement: Investigating a multilevel cross- classified model. Journal of Educational Administration, 47(2), 227-249.

Henard, F. (2009) Learning our lesson; Review of Quality Teaching in Higher Education, draft report, Paris:OECD

Henard, F., \& Roseveare, D. (2012). Fostering quality teaching in higher education: Policies and practices. An IMHE Guide for Higher Education Institutions, 7-11.

Henderson, K. D. (2016). The Effect of Higher Education Classroom Behavior Management Strategies on Learning (Doctoral dissertation, Walden University).

Hodge, R. L. (1971). Interpersonal classroom communication through eye contract. Theory into Practice, 10(4), 264-267.

Hommel, B., Müsseler, J., Aschersleben, G., \& Prinz, W. (2001). The theory of event coding (TEC): A framework for perception and action planning. Behavioral and brain sciences, 24(5), 849-878.

Hopkins, D., \& Stern, D. (1996). Quality teachers, quality schools: International perspectives and policy implications. Teaching and teacher education, 12(5), 501-517. 
Hsu, L. (2010). The impact of perceived teachers' nonverbal immediacy on students' motivation for learning English. Asian EFL Journal, 12(4), 188-204.

Jawaharlal, M. (2017, July 19). Professors Must Learn How to Teach. Retrieved from July 30, 2019, https://www.huffpost.com/entry/professors-must-learn-how-toteach_b_593b66e4e4b0b65670e56a80

Jeelani, I., Han, K., \& Albert, A. (2018). Automating and scaling personalized safety training using eye-tracking data. Automation in Construction, 93(May), 63-77.

Jerez, O., Ortiz, C., Rojas, M., \& Henríquez, F. (2018). Classroom Management in Large Higher Education Courses: Challenges and Opportunities. EDULEARN18 Proceedings, 1(August), 8766-8771.

Kaufman, D., \& Ireland, A. (2016). Enhancing Teacher Education with Simulations. TechTrends, 60(3), 260-267.

Khan, N., Mohammad, N., Shah, N., \& Farid, N. (2016). A Study of the Use of Eye Contact in Teaching Learning Process at Secondary Level in District Peshawar. Language in India, 16(4).

Kulik, J., \& McKeachie, W. (1975). The Evaluation of Teachers in Higher Education. American Educational Research Association, 3, 210-240. 
Ladeji-Osias, J. O., \& Wells, A. M. (2014, June). Best Practices in Classroom Management for Today's University Environment. In 121st ASEE Annual Conference \& Exposition.

Ledbury, R., White, I., \& Darn, S. (2004). The Importance of eye contact in the classroom. The Internet TESL Journal, 10(8), 1-2.

Lemmer, E.M., Meier, C. \& Van Wyk, N. (2012). Multicultural education: A manual for the South African Teacher, (2nd ed.). Pretoria: Van Schaik.

Liu, X., \& Gale, A. (2007). Searching for possible threat items to safe air travel: Human error and training. 7th International Conference on Engineering Psychology and Cognitive Ergonomics, EPCE 2007, 4562 LNAI, 750-759.

Luo, J., Bellows, L., \& Grady, M. (2000). Classroom management issues for teaching assistants. Research in Higher Education, 41(3), 353-383.

MacInnes, J. J., Iqbal, S., Pearson, J., \& Johnson, E. N. (2018). Wearable Eye-tracking for Research: Automated dynamic gaze mapping and accuracy/precision comparisons across devices. bioRxiv, 299925.

Marzano, R. J., Marzano, J. S., \& Pickering, D. (2003). Classroom management that works: Research-based strategies for every teacher. ASCD. 
Marzano, R. J., \& Marzano, J. S. (2003). The Key to Classroom Management. Educational Leadership, 61(1), 6-13.

METU Center for Advancing Learning and Teaching (2019). Our Goals. Retrieved from June 28, 2019, http://ogem.metu.edu.tr/en/our-goals

Meyers, S. A. (2003). Strategies to prevent and reduce conflict in college classrooms. College teaching, 51(3), 94-98.

McIntyre, N. A., Mainhard, M. T., \& Klassen, R. M. (2017). Are you looking to teach? Cultural, temporal and dynamic insights into expert teacher gaze. Learning and Instruction, 49, 41-53

Moore, L. J., Vine, S. J., Cooke, A., Ring, C., \& Wilson, M. R. (2012). Quiet eye training expedites motor learning and aids performance under heightened anxiety: The roles of response programming and external attention. Psychophysiology, 49(7), 1005-1015.

Muehlethaler, C. M., \& Knecht, C. P. (2016). Situation awareness training for general aviation pilots using eye-tracking. IFAC-PapersOnLine, 49(19), 66-71.

O’Neill, E. C., Kong, Y. X. G., Connell, P. P., Ong, D. N., Haymes, S. A., Coote, M. A., \& Crowston, J. G. (2011). Gaze behavior among experts and trainees during optic disc examination: Does how we look affect what we see? Investigative Ophthalmology and Visual Science, 52(7), 3976-3983. 
OECD. (2017). Benchmarking Higher Education System Performance: Conceptual framework and data. Enhancing Higher Education System Performance, 97. Retrieved from July 5, 2019, https://www.oecd.org/education/skills-beyondschool/Benchmarking\%20Report.pdf

Ödalen, J., Brommesson, D., Erlingsson, G. Ó., Schaffer, J. K., \& Fogelgren, M. (2019). Teaching university teachers to become better teachers: the effects of pedagogical training courses at six Swedish universities. Higher Education Research \& Development, 38(2), 339-353.

Özben, Ş. (2010). Teachers' strategies to cope with student misbehavior. Procediasocial and behavioral sciences, 2(2), 587-594.

Palmer, C. (2009, January 27). Building Student Engagement: Classroom Atmosphere. Retrieved from July 20, 2019, https://www.facultyfocus.com/articles/effectiveclassroom management/building-student-engagement-classroom-atmosphere/

Patton, M. (1990). Purposeful sampling. Qualitative evaluation and research methods, 2, 169-186.

Poole, A., \& Ball, L. J. (2006). Eye tracking in HCI and usability research. In Encyclopedia of human computer interaction (pp. 211-219). IGI Global. 
Postareff, L., Lindblom-Ylänne, S., \& Nevgi, A. (2007). The effect of pedagogical training on teaching in higher education. Teaching and teacher education, 23(5), $557-571$.

Restuningrum, N. (2018). Teachers' Strategy of Positioning in Teaching Young Learners. International Journal of Educational Best Practices, 2(1), 1-13.

Salomons, A., \& Goos, M. (2014). Measuring teaching quality in higher education: Assessing the problem of selection bias in course evaluations. Discussion paper series/Tjalling C. Koopmans Research Institute, 14(16), 1-41.

Sánchez-Ferrer, M. L., Grima-Murcia, M. D., Sánchez-Ferrer, F., HernándezPeñalver, A. I., Fernández-Jover, E., \& Sánchez del Campo, F. (2017). Use of Eye-tracking as an Innovative Instructional Method in Surgical Human Anatomy. Journal of Surgical Education, 74(4), 668-673.

Sanders, W. L., Wright, S. P., \& Horn, S. P. (1997). Teacher and classroom context effects on student achievement: Implications for teacher evaluation. Journal of personnel evaluation in education, 11(1), 57-67.

Sanfilippo, F. (2017). A multi-sensor fusion framework for improving situational awareness in demanding maritime training. Reliability Engineering and System Safety, 161(February 2016), 12-24. 
Seeman, H. (2009). Preventing disruptive behavior in colleges: A campus and classroom management handbook for higher education. R\&L Education.

Schleicher, A. (2015). Value-Added: How do you measure whether universities are delivering for their students? HEPI 2015 Annual Lecture About the Author. Retrieved from June, 15, 2019, http://www.hepi.ac.uk/wpcontent/uploads/2016/01/Andreas-Schleicher-lecture.pdf

Schutz, A. C., Braun, D. I., \& Gegenfurtner, K. R. (2011). Eye movements and perception: A selective review. Journal of Vision, 11(5), 9-9.

Tanner, C. K. (2008). Explaining relationships among student outcomes and the school's physical environment. Journal of Advanced Academics, 19, 444-471. doi:10.4219/jaa-2008-812

Teegavarapu, S., \& Summers, J. D. (2008). Case study method for design research. Proceedings of IDETC/DTM, 3-6.

Tien, T., Pucher, P. H., Sodergren, M. H., Sriskandarajah, K., Yang, G. Z., \& Darzi, A. (2014). Eye-tracking for skills assessment and training: A systematic review. Journal of Surgical Research, 191(1), 169-178.

Üstünlüoğlu, E. (2017). Teaching quality matters in higher education: A case study from Turkey and Slovakia. Teachers and Teaching, 23(3), 367-382. 
Van De Merwe, K., Van Dijk, H., \& Zon, R. (2012). Eye movements as an indicator of situation awareness in a flight simulator experiment. The International Journal of Aviation Psychology, 22(1), 78-95.

Van den Bogert, N., van Bruggen, J., Kostons, D., \& Jochems, W. (2014). First steps into understanding teachers' visual perception of classroom events. Teaching and Teacher Education, 37, 208-216.

Vieira, M. M. da S., \& Neto, B. G. A. (2016). Peer Instruction: Continuing Teacher Education in Higher Education. Procedia - Social and Behavioral Sciences, 217, 249-256.

Vine, S. J., Masters, R. S. W., McGrath, J. S., FRCS, Bright, E., \& Wilson, M. R. (2012). Cheating experience: Guiding novices to adopt the gaze strategies of experts expedites the learning of technical laparoscopic skills. Frontiers in Plant Science, 152(1), 32-40.

Vine, S. J., \& Wilson, M. R. (2010). Quiet eye training: Effects on learning and performance under pressure. Journal of Applied Sport Psychology, 22(4), 361376.

Weibel, N., Fouse, A., Emmenegger, C., Kimmich, S., \& Hutchins, E. (2012). Let's look at the Cockpit : Exploring Mobile Eye-Tracking for Observational Research on the Flight Deck. Proceedings of the Symposium on Eye-tracking Research and Applications - ETRA '12, 1(212), 107-114. 
Weinstein (Eds.), Handbook of classroom management. Research, practice, and contemporary issues (pp. 309-341). New York / London: Lawrence Erlbaum Associates.

Wilson, M. R., Vine, S. J., Bright, E., Masters, R. S. W., Defriend, D., \& McGrath, J. S. (2011). Gaze training enhances laparoscopic technical skill acquisition and multi-tasking performance: A randomized, controlled study. Surgical Endoscopy, 25(12), 3731-3739.

Wolff, C. E., Jarodzka, H., \& Boshuizen, H. P. A. (2017). See and tell: Differences between expert and novice teachers' interpretations of problematic classroom management events. Teaching and Teacher Education, 66, 295-308.

Wolff, C. E., Jarodzka, H., van den Bogert, N., \& Boshuizen, H. P. A. (2016). Teacher vision: expert and novice teachers' perception of problematic classroom management scenes. Instructional Science, 44(3), 243-265.

Wood, G., \& Wilson, M. R. (2011). Quiet-eye training for soccer penalty kicks. Cognitive Processing, 12(3), 257-266.

Woolfolk, A. E., \& Brooks, D. M. (1985). The influence of teachers' nonverbal behaviors on students' perceptions and performance. The Elementary School Journal, 85(4), 513-528. 
Wubbels, T., Brekelmans, M., Van Tartwijk, J., \& Admiraal, W. (1999). Interpersonal relationships between teachers and students in the classroom. In H.C. Waxman \& H.J. Walberg (Eds.), New directions for teaching practice and research (pp. 151170). Berkeley, CA: McCutchan.

Yamamoto, T., \& Imai-Matsumura, K. (2012). Teachers' Gaze and Awareness of Students' Behavior: Using An Eye Tracker. Comprehensive Psychology, 2, 01.IT.2.6, 1-7.

Yarbrough, C., \& Price, H. E. (1981). Prediction of performer attentiveness based on rehearsal activity and teacher behavior. Journal of Research in Music Education, 29(3), 209-217.

Zainal, Z. (2007). Case study as a research method. Jurnal Kemanusiaan, 5(1).

Zeki, C. P. (2009). The importance of non-verbal communication in classroom management. Procedia-Social and Behavioral Sciences, 1(1), 1443-1449. 


\section{APPENDICES}

\section{A. Interview Questions}

1) What do you think about the use of wearable eye tracker in assessing classroom management performance?

2) Did eye tracker give you meaningful feedback about classroom management?

3) Do you think wearable eye tracker can be used to train faculty members about classroom management?

4) Did eye tracker disturb you while lecturing? 


\section{B. Voluntary Participation Form (Turkish)}

$\mathrm{Bu}$ araştırma, ODTÜ, Bilgisayar ve Öğretim Teknolojileri Bölümünde (BÖTE) öğretim görevlisi olarak çalışan Prof. Dr. Kürşat ÇAĞILTAY danışmanlığında, ODTÜ, BÖTE Yüksek Lisans öğrencisi Atakan ÇOŞKUN tarafından yürütülmektedir. $\mathrm{Bu}$ form sizi araştırma koşulları hakkında bilgilendirmek için hazırlanmıştır.

\section{Çalışmanın Amacı Nedir?}

Araştırmanın amacı, giyilebilir göz takip cihazının (Tobii Pro Glasses 2) öğretmenlerin sınıf yönetimi ve öğretim tekniklerini değerlendirmede kullanılıp kullanılmayacağını araştırmaktır.

\section{Bize Nasıl Yardımcı Olmanızı İsteyeceğiz?}

Araştırmaya katılmayı kabul ederseniz, giyilebilir göz takip cihazını (Tobii Pro Glasses 2) kullanarak sadece 50 dakikalık ders süresi kapsamında, 3 hafta boyunca, sınıf ortamı içerisinde, ders anlatırken göz hareketlerinizi kaydedeceğiz. Buna ek olarak video kamera aracılığıyla sınıfı içerisindeki hareketlerinizi de kaydedeceğiz. Göz ve video kaydı alındığg hafta içerisinde, göz ve video kayıtlarına ait analizler sizlere gösterilip, sizden yorumlamanız beklenilecektir. Yapmış olduğunuz yorumlar ses kaydına alınacaktır. Çalışma ile ilgili veri alma süreci aşağıdaki tabloda (Tablo 1) özetlenmiştir.

\begin{tabular}{|l|l|l|}
\hline \multicolumn{3}{|c|}{ Tablo 1: Veri Alma Süreci } \\
\hline 1. Hafta & $\begin{array}{l}50 \text { dakikalık ders içerisinde göz hareketleri kaydedilecek olup } \\
\text { giyilebilir göz takip cihazı (Tobii Pro Glasses 2) ile kaydedilecektir. } \\
\text { Ayrıca video kamera aracılığıyla öğretmenin sınıf içerisindeki } \\
\text { hareketleri kaydedilecektir. }\end{array}$ \\
\hline 1. Hafta & $\begin{array}{l}\text { Göz hareketleri ve video kamera görüntüleri analiz edilecek ve } \\
\text { öğretmene gösterilecektir. Öğretmenden, göz hareketlerinin ve video }\end{array}$ \\
\hline
\end{tabular}




\begin{tabular}{|l|l|}
\hline & $\begin{array}{l}\text { görüntülerin yorumlanması istenilecektir. Öğretmenin yorumları ses } \\
\text { kaydı aracılığıyla kaydedilecektir. }\end{array}$ \\
\hline $\begin{array}{l}\text { 2. Hafta } \\
\text { (Tekrar) }\end{array}$ & $\begin{array}{l}50 \text { dakikalık ders içerisinde göz hareketleri kaydedilecek olup } \\
\text { giyilebilir göz takip cihazı (Tobii Pro Glasses 2) ile kaydedilecektir. } \\
\text { Ayrıca video kamera aracılığıyla öğretmenin sınıf içerisindeki } \\
\text { hareketleri kaydedilecektir. }\end{array}$ \\
\hline $\begin{array}{l}\text { 2. Hafta } \\
\text { Tekrar) }\end{array}$ & $\begin{array}{l}\text { Göz hareketleri ve video kamera görüntüleri analiz edilecek ve } \\
\text { görüntülerin yorumlanması istenilecektir. Öğretmenin yorumları ses } \\
\text { kaydı aracılığıyla kaydedilecektir. }\end{array}$ \\
\hline $\begin{array}{l}\text { 3. Hafta } \\
\text { (Tekrar) }\end{array}$ & $\begin{array}{l}\text { g0 dakikalık ders içerisinde göz hareketleri kaydedilecek olup } \\
\text { giyilebilir göz takip cihazı (Tobii Pro Glasses 2) ile kaydedilecektir. } \\
\text { Ayrıca video kamera aracıllı̆̆ıla öğretmenin sınıf içerisindeki } \\
\text { hareketleri kaydedilecektir. }\end{array}$ \\
\hline $\begin{array}{l}\text { 3. Hafta } \\
\text { (Tekrar) }\end{array}$ & $\begin{array}{l}\text { Göz hareketleri ve video kamera görüntüleri analiz edilecek ve } \\
\text { öretmene gösterilecektir. Öğretmenden, göz hareketlerinin ve video } \\
\text { kaydı aracılığıyla kaydedilecektir. }\end{array}$ \\
\hline
\end{tabular}

\section{Sizden Topladığımız Bilgileri Nasıl Kullanacağız?}

Araştırmaya katılımınız tamamen gönüllülük temelinde olmalıdır. Veriler sadece yüksek lisans tezi kapsamında akademik bir çalışma için kullanılacaktır. Cevaplarınız tamamıyla gizli tutulacak, sadece araştırmacılar tarafindan değerlendirilecektir. Katılımcılardan elde edilecek bilgiler ayrı ayrı değerlendirilecek ve bilimsel yayımlarda kullanılacaktır. Sağladığınız veriler gönüllü katılım formlarında toplanan kimlik bilgileri ile kesinlikle eşleştirilmeyecektir.

Katılımınızla ilgili bilmeniz gerekenler: 
Tobii Pro Glasses 2 (giyilebilir göz takip cihazı) kullanıcıya kişisel ve fiziksel rahatsızlık vermemektedir. Bununla ilgili olarak cihazın uygunluk beyanı da ekte yer almaktadır. Ancak, katılım sırasında cihazdan ya da herhangi başka bir nedenden ötürü kendinizi rahatsız hissederseniz çalışma işini yarıda bırakıp çıkmakta serbestsiniz. Böyle bir durumda çalışmayı uygulayan kişiye, çalışmadan çıkmak istediğinizi söylemek yeterli olacaktır.

\section{Araștırmayla ilgili daha fazla bilgi almak isterseniz:}

Bu çalışmaya katıldığınız için şimdiden teşekkür ederiz. Çalışma hakkında daha fazla bilgi almak için ODTÜ öğretim üyelerinden Prof. Dr. Kürşat ÇAĞILTAY (E-posta: kursat@metu.edu.tr) ya da ODTÜ Yüksek Lisans öğrencisi Atakan ÇOŞKUN (Eposta: atakancoskun45@gmail.com) ile iletişim kurabilirsiniz.

Yukarıdaki bilgileri okudum ve bu çalışmaya tamamen gönüllü olarak katılıyorum.

(Formu doldurup imzaladıktan sonra uygulayıcıya geri veriniz).

İsim Soyad Tarih Imza

$---/---/----$

Ek-1: Uygunluk beyanı (Declaration of Confirmity) 


\section{tobiipro}

\section{Declaration of Conformity}

We, Tobil AB, hereby declare that the product identified herein complies with the following EC directives:
- EMC
2014/30/EU
- Low Voltage
2014/35/EU
- RED
2014/53/EU
- RoHS 2
2011/65/EU

Product name/model: $\quad$ Tobil Pro Glasses 2

Product description: Mobile eye tracker

Intended use:

Research

The following standards have been used:

- EMC
EN 55032-2012/AC:2013 Class B
EN 55011:2009+A1:2010 Class B
EN 55024:2010/A1:2015
EN 61000-3-2:2014
EN $61000-3-3: 2013$
EN 61000-6-1:2007
EN 61000-6-3:2007/A1:2011

- Low Voltage (Safety)
- EN 60950-1:2006/A11:2009/A1:2010/A12:2011/A2:2013 EN-62471:2008
ETSI EN 300328 V1.8.1 (2012-06)
ETSI EN 301893 V1.7.1 (2012-06)
ETSI EN 301 489-1 V2.2.0 (2017-03)
ETSI EN 301 489-17 V3.2.0 (2017-03)
EN 50566:2013/AC:2014
EN 62311:2008
- EN 62209-2:2010

- RED

I hereby declare that the equipment named above has been designed to comply with the relevant sections of the above referenced specifications. The unit complies with all essential requirements. Stockholm, 2018-01-23

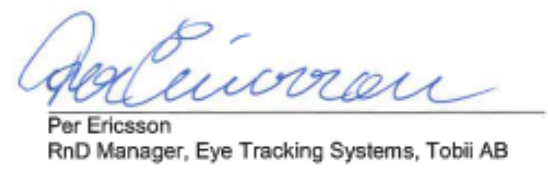

Tabi $A B$

S.182 17 Dandend Sweden

phone: +4886836990

www.tobicrocom 


\section{Ethics Approval Form (Turkish)}

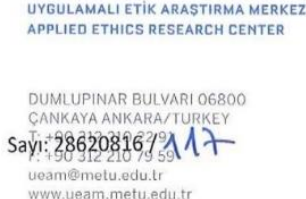

Konu: Değerlendirme Sonucu

Gönderen: ODTÜ Insan Araştırmaları Etik Kurulu (iAEK)

ilgi: $\quad$ insan Araştırmaları Etik Kurulu Başvurusu

\section{Sayın Prof.Dr. Kürşat ÇAĞILTAY}

Danışmanlığını yaptığınız Atakan CCOSSKUN'un "Investigation Of Teaching and Classroom Management Skill Using Eye Tracking Technology" başııkı araștırması Insan Araştırmaları Etik Kurulu tarafından uygun görülmüş ve 108-ODTÜ-2019 protokol numarası ile onaylanmıştır.

Saygılarımızla bilgilerinize sunarı.

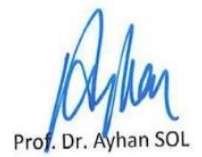

Üye

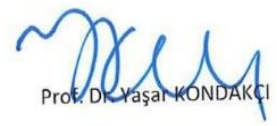

Üye

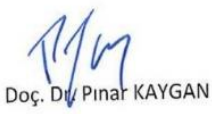

Üye

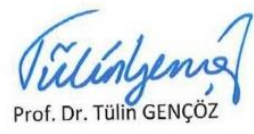

Başkan

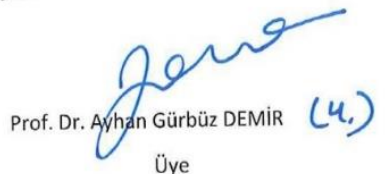

Doç. Dr. Emre SELÇUK

Üye

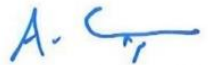

Dr. Öğr. Üyesi Ali Emre TURGUT

Üye 